\title{
An Assessment of the Radon Concentrations in Air Caused by Emissions from Multiple Sources in a Uranium Mining and Milling Region. A Case Study of the Ambrosia Lake Region of New Mexico
}

Decembèr 1981

Prepared for the U.S. Environmental Protection Agency under an Interagency Agreement with the U.S. Department of Energy under Contract DE-AC06-76RLO 1830

Pacific Northwest Laboratory Operated for the U.S. Department of Energy by Battelle Memorial Institute 
NOTICE

This report was prepared as an account of work sponsored by the United States Government. Neither the United States nor the Department of Energy, nor any of their employees, nor any of their contractors, subcontractors, or their employees. makes any warranty, express or implied. or assumes any legal liability or responsibility for the accuracy, completeness or usefulness of any information, apparatus. product or process disclosed, or represents that its use would not infringe privately owned rights.

The views. opinions and conclusions contained in this report are those of the contractor and do not necessarily represent those of the United States Government or the United States Department of Energy.

PACIFIC NORTHWEST LABORATORY

operated by

BATTELLE

for the

UNITED STATES DEPARTMENT OF ENERCY

Under Contract DE-AC06-76RLO 1830

\author{
Printed in the United States of America \\ Available from \\ National Technical Information Service \\ United States Department of Commerce \\ 5285 Port Royal Road \\ Springfield. Virginia 22151
}

Price: Printed Copy $\$$

$\because$ Microfiche $\$ 3.00$

NTIS

-Pages Selling Price

$\begin{array}{lr}001-025 & \$ 4.00 \\ 026-050 & \$ 4.50 \\ 051-075 & \$ 5.25 \\ 076-100 & \$ 6.00 \\ 101-125 & \$ 6.50 \\ 126-150 & \$ 7.25 \\ 151-175 & \$ 8.00 \\ 176-200 & \$ 9.00 \\ 201-225 & \$ 9.25 \\ 226-250 & \$ 9.50 \\ 251-275 & \$ 10.75 \\ 276-300 & \$ 11.00\end{array}$




\begin{abstract}
AN ASSESSMENT OF THE RADON CONCENTRATIONS IN AIR CAUSED BY EMISSIONS FROM MULTIPLE SOURCES IN A URANIUM MINING AND MILLING REGION. A CASE STUDY OF THE AMBROSIA LAKE REGION OF NEW MEXICO
\end{abstract}

J. G. Droppo

J. A. Glissmeyer

December 1981

Prepared for the U.S. Environmental Protection Agency under an Interagency Agreement with the U.S. Department of Energy under Contract DE-AC06-76RL0-1830

Project Officer

Paul J. Magno

Office of Radiation Programs (ANR 460)

U.S. Environmental Protection Agency Washington, DC 20460

Pacific Northwest Laboratory Richland, Washington 99352 
. 


\section{ABSTRACT}

Uranium mining and milling operations result in the release of radon from numerous sources of various types and strengths. The Ambrosia Lake mining and milling operations were selected to characterize the relative importance of these sources on ambient atmospheric radon concentrations. All uranium mines at Ambrosia Lake are underground. The comparisons of interest were both between the sources and between the sources and background concentrations. Source strengths for mine vents were estimated from field measurements made in previous studies. Emission rates for active and inactive mill tailings piles were estimated using data from several of the sites. Emission estimates were made for sites with no data. Other sources from uranium mining and milling were assumed to be small relative to these emissions.

Annual average radon concentrations were computed from the over one hundred vent and four mill tailings pile sources using a sector average Gaussian dispersion model. Ground level point source releases were assumed for vent emissions and ground level virtual point source releases were assumed for the tailings piles.

The results show that vents are by far the greatest source of the computed radon concentrations in the immediate area of the operations. The computed radon concentrations at receptor points were largely influenced by the closer sources, rather than by more distant stronger sources. The area where computed radon concentrations significantly exceed the background is confined to the general area around the vents and mills.

A comparison between computed radon concentrations and monitoring data at selected points demonstrates order of magnitude aggrement. The comparison is 7 imited by different time periods for the computed and monitored values, but does not show that the elevated radon concentrations monitored in such regions are of the same order as computed from the uranium mining and milling emissions. 


\section{CONTENTS}

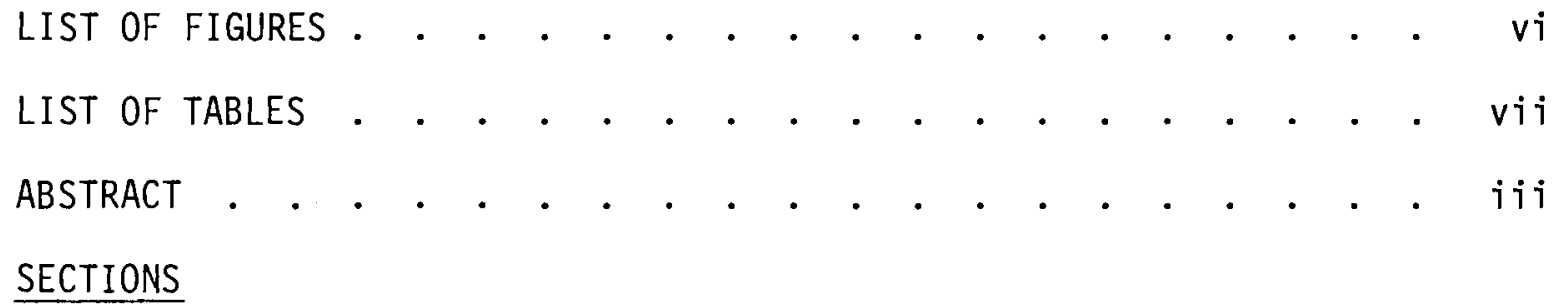




\section{FIGURES}

Page

1. Geographical Features of the Ambrosia Lake District 2

2. Frequency Plot of Mine Vent Source Terms for Spring 1979 Data 10

3. Detailed Map of Mining Area Showing Source and Receptor Points 13

4. Comparison of Monitored and Computed Radon Concentrations 18

5. Computed Radon Concentration Map for Region 20

6. Computed Radon Concentration Map for Intensive Mining Area 22 
1. Annual Wind Speed, Wind Direction, and Stability Joint 8 Frequency Summary for the Mining Area

2. Comparisons of Onsite Stability with Other STAR Regional Data 9

3. Number of Mine Vents Sampled 9

4. Tailings Pile Source Terms 11

5. Source Terms for Vents and Tailings Piles 14

6. Receptor Locations 15

7. Average Computed and Monitored Radon Concentrations 17

8. Number of Large Sources that Account for 10,50 and $90 \%$ of
the Computed Radon Concentrations at Each Receptor

9. Sources with the Largest Comouted Concentration at Each 25 Receptor

Appendix Tables
A.1 - A.12 Computed Radon Concentrations at Receptors Ranked by Source Size
A.13 - A.24 Computed Radon Concentrations at Receptors Ranked by Computed Concentrations


4

, 


\section{SECTION I}

\section{INTRODUCTION}

Uranium mining and milling operations result in the release of radon from numerous sources of various types and strength. EPA, under the Clean Air Act, is assessing the health impact of air emissions of radon from various sources, including uranium mines. In the case of uranium mines, multiple sources of radon emissions are often located relatively close together. Therefore, it is necessary for EPA to know the extent to which these multiple sources increase the radon concentration in the air in the mining region and particularly at locations where people may be living. To obtain this type of information, the Ambrosia Lake District of New Mexico was chosen as a "case study". This area was selected because it contained a large number of radon sources for which emission data are available. In addition, radon monitoring data are available for a number of locations in this region.

This region has intensive underground mining with shafts and vents located on a low broad flat area located between several mesas. The geographical features of the Ambrosia Lake area are shown in Figure 1. The dashed area encloses the intensive mining area. Four mill tailings piles are outlined and labeled by letters, A, B, C, and D. Piles A and B are within the mining dashed area, $C$ and $D$ occur below and to the left of the mining area.

Relative contributions of radon are evaluated based on atmospheric modeling of the combinations of the many radon sources. This involves characterization of the source in terms of location and emission rate for input to an atmospheric dispersion model. This model incorporates the local dispersion characteristics to compute atmospheric radon concentrations from the various sources at selected locations.

Annual average radon concentrations are selected for study as being appropriate to EPA interests. In addition, this permits use of models that allow inclusion of a large number of sources without requiring excessive computations.

In addition to releases from various facets of mining and milling, radon is also released from natural sources. The latter occur lárgely as soil emissions over the entire region. Natural outcropings of uranium deposits may result 


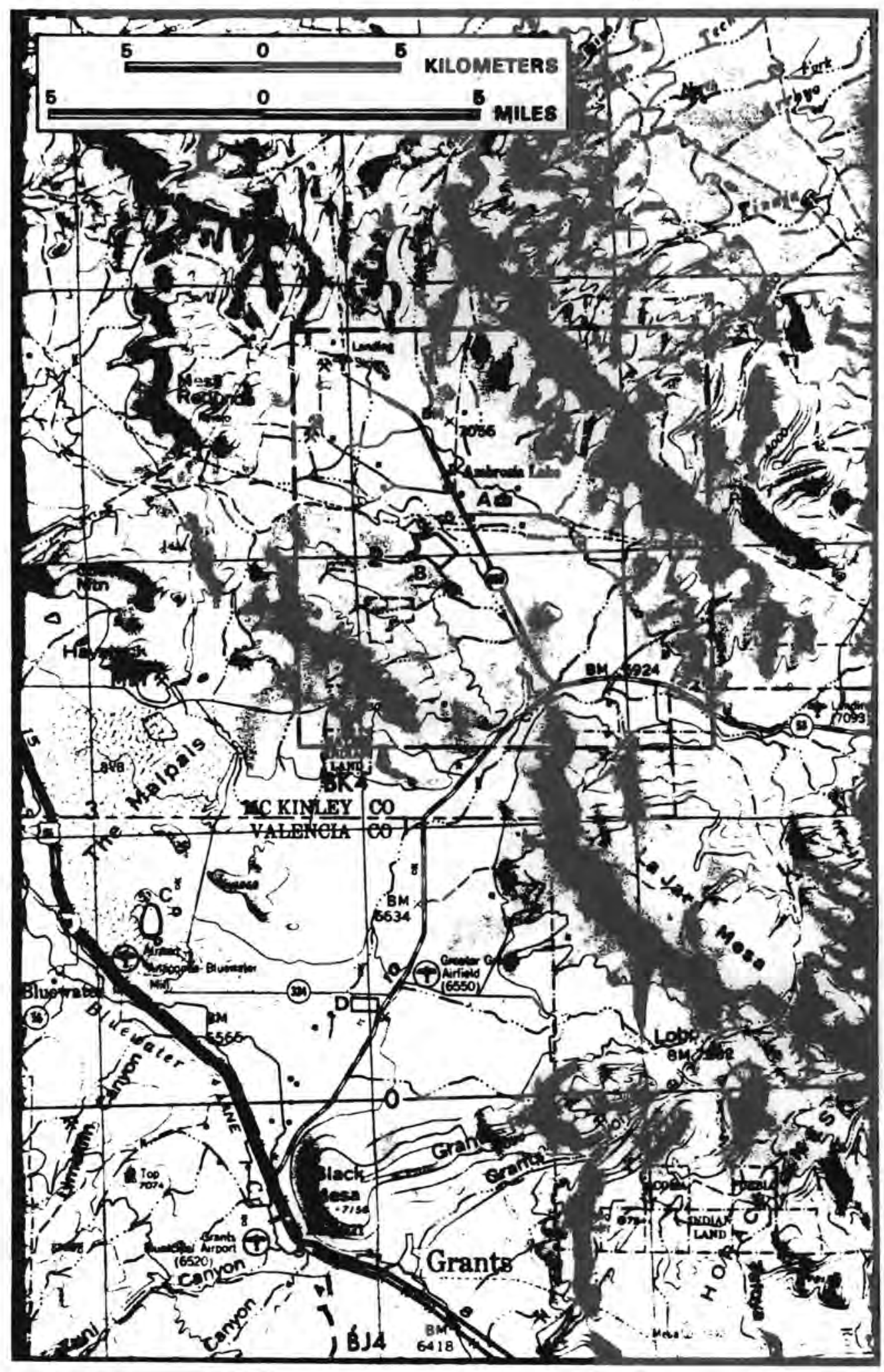

FIGURE 1. GEOGRAPHICAL FEATURES OF THE AMBROSIA LAKE DISTRICT 
in higher local emissions. Natural emissions maintain a background radon concentration to which the radon contributions from the uranium mining and milling are assumed to be additive.

Al though the natural radon emissions through the soil and rocks represent a large total emission over the region, the lack of data on spatial variability precludes inclusion in the radon modeling. Instead, the natural emissions are characterized in terms of an estimated range of background radon concentrations based on monitoring data.

The mine vents and mill tailings piles have by far the greatest total annual radon releases related to the mining and milling operations. In the next section these two groups of sources are used to characterize the radon emissions. Other sources (i.e., ore storage piles, subore and waste rock piles, etc.) are assumed to be sufficiently small that they can be neglected without changing the results.

The large number of sources in the region dictates using relatively simple models and assumptions to keep the required computations within the scope of this evaluation. Although this will limit some aspects of the results, sufficient detail is maintained to meet the objectives related to the comparison of the relative importance of various radon emissions. 


\section{SECTION II}

METHODOLOGY

Annual average radon concentrations from the multiple radon sources are computed using a Gaussian dispersion model. The following is a description of this dispersion model and the preparation of input data. This involved characterization of local dispersion, identification of radon source locations and emission rates, and selection of receptor locations.

\section{Atmospheric Dispersion Model}

The modeling of atmospheric dispersion and transport is kept within reasonable computational limits by selecting appropriate but efficient models and assumptions. Hence from a range of possible dispersion models, a relatively simple model is selected to study relative radon concentrations. The sector averaged Gaussian plume model used to compute average annual radon air concentrations is based directly on many of the alogrithms documented by Busse and Zimmerman (1973) as applicable to a rural region.

The sector average concentration $\bar{C}_{n}$ resulting from point source $n$ is given by

$$
\bar{C}_{n}=\frac{16}{2 \pi} \sum_{\ell=1}^{6} \sum_{m=1}^{6} \frac{\phi\left(k_{n}, \ell, m\right) G_{n} S\left(\rho_{n}, z ; U_{\ell}, P_{m}\right)}{\rho_{n}}
$$

where

$$
\begin{aligned}
k_{n}= & \text { wind sector appropriate to the } n^{\text {th }} \text { point source } \\
G_{n}= & \text { emission rate of the } n^{\text {th }} \text { point source } \\
\rho_{n}= & \text { distance from the receptor to the } n^{\text {th }} \text { source } \\
\ell= & \text { index identifying the wind speed class } \\
m= & \text { index identifying the class of the Pasquill stability } \\
& \text { category } \\
\phi(k, \ell, m)= & \text { joint frequency function of wind speed, wind } \\
S\left(\rho, z ; U_{\ell}, P_{m}\right)= & \text { dispersion function defined in Equation } 3 \\
z= & \text { height of receptor above ground level } \\
U_{\ell}= & \text { class interval wind speed } \\
P_{m}= & \text { Pasquill stability category }
\end{aligned}
$$


The sector average concentration ct resulting from $t$ sources is given by

$$
c t=\sum_{n=1}^{t} \overline{c n}
$$

The receptor is assumed to be at ground level, that is, $z=0$, making the dispersion function

$$
S\left(\rho_{n}, 0 ; U_{\ell}, p_{m}\right)=\frac{2}{\sqrt{2 \pi} U_{\ell} \sigma_{z}\left(\rho_{n}\right)} \exp \left[-\frac{1}{2}\left(\frac{h}{\sigma_{z}\left(\rho_{n}\right)}\right)^{2}\right] \exp \left(\frac{0.692 \rho_{n}}{U_{\ell}^{\top} 1 / 2}\right)
$$

New terms in Equation 3 are defined as

$$
\begin{aligned}
\sigma_{z}\left(\rho_{n}\right)= & \text { vertical dispersion function, i.e., the normalized } \\
& \text { standard deviation of the radon concentration in } \\
& \text { the vertical plane } \\
h= & \text { effective stack height of source, meters } \\
T_{1 / 2}= & \text { half life of radon, hours }
\end{aligned}
$$

The values of vertical dispersion parameter in the six Pasquill stability categories as a function of downwind distance are taken directly from Busse and Zimmerman (1973).

All radon releases are assumed to be at ground level. The exponential containing the release height reduces to unity in Equation 3. The diverse nature of the release modes for the large number of radon releases dictates this as a first step approximation. Although none of the releases occur through a conventional stack, many of the near surface mine vent releases have initial momentum and/or thermal bouyancy that may result in at least low level plume rise. This uncertainty in plume rise characteristics limits the reliability of concentration computed very near the releases.

Atmospheric mixing height considerations are not included. The processes controlling the order of magnitude of the radon concentrations at the relatively close distances are the limited nocturnal dispersion from surface releases. Mixing height limitations are not important under these conditions. 
The possibility of radon decay is included in the last exponential in Equation 3. This term is assumed to be unity in this analysis. The relatively short travel times for the distances of interest in this analysis compared to the radon half time of 3.82 days makes this a trivial influence on the computed concentrations.

The mill tailings piles are modeled as virtual area sources using the point source equations given above. One half of the average crosswind widths are used to define the initial dispersion values in terms of a virtual upwind distance of $\rho_{v}$. The average concentrations from the area sources are computed using the distance value, $\rho$, computed as the sum of actual and virtual distances.

Output summaries of both $\bar{C} n$ and $\bar{C} t$ are necessary to study the relative contributions of the radon sources. The procedure is to study the fractional radon contributions at a number of selected receptor points in the region. In addition computed radon concentration maps from all emissions are generated to study the spatial characteristics.

\section{Local Meteorological Data}

Complex air flow patterns result from the complex topography in this region (Figure 1). Studies show that nocturnal air flow patterns are related to topographically induced air drainage flow (Gedayloo et al, 1979). Since the concentrations computed for near surface releases will be largest for nighttime stable conditions, the characterization of the onsite meteorological conditions is particularly important for complex meteorological areas such as this.

One annual cycle of meteorological data from a central location in this mining and milling area was supplied by Mr. William Fort, Programs, Environmental Protection Agency, Las Vegas, NV. This consisted of time, wind speed and direction, and precipitation values on a computer tape. A STAR ${ }^{1}$ scheme in modified form is used to generate joint wind speed, direction, and stability tables. The procedure uses wind speeds, solar angle, and precipitation values to define stability groups. All conditions from one hour after local sunset to one hour before sunrise are considered stable unless winds are greater than $5 \mathrm{~m} / \mathrm{s}$. In the latter case conditions are considered night neutral stability.

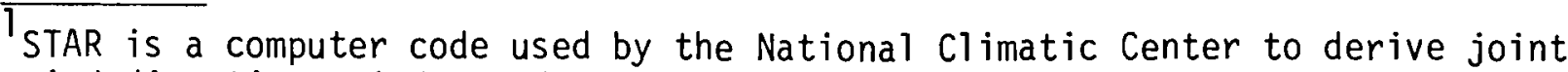
wind direction, wind speed and stability summaries from hourly surface observations. 
Day neutral stability conditions are considered to occur over two hour transition periods at sunrise and sunset, for daytime conditions with winds greater than $4 \mathrm{~m} / \mathrm{s}$, and during precipitation. The remaining daytime periods are considered unstable. The frequencies of the three unstable Pasquill classes are derived by apportioning the unstable based on the frequencies for unstable conditions from a station located $25 \mathrm{~km}$ to the south of the mining area.

The annual percentage occurrences of wind speed, direction, and stability class based on onsite meteorological data are in Table 1. Allowing for expected site specific differences, this summary is consistent with other summaries at other locations in this region. Table 2 shows the total frequencies in stability groups are comparable. However, the onsite data have larger frequencies of low wind speeds and differences in wind direction frequency peaks. These differences underline the importance of use on onsite data for the mining and milling operations area.

\section{Source Definition}

The radon emission locations are four uranium mill tailings piles and vents of twenty underground uranium mines. This section describes the methods and references used to estimate source terms for these emissions.

For the mine vents, extensive use is made of emissions reported by Jackson, et al $(1979,1980)$. Radon emissions from vents were measured in two campaigns in the Fall 1978 and Spring 1979. Each vent sampling consisted of an air flow measurement and a pair of grab samples using evacuated scintillation flasks. Table 3 summarizes the number of vents sampled, inoperative (zero emission values) or missed during each campaign. Where possible, each vent was sampled twice during each campaign. With the combination of both campaigns, only the vents of two small underground mining operations were unaccounted for. Based upon limited knowledge of these two small operations it is estimated that one had two vents and the other just one. This means emission measurements are available for 114 vents out of an estimated 117 total vents.

A plot of the number of mine vents versus emission rate is given in Figure 2 for the spring measurements. The spring.-campaign has the most complete coverage. Logarithm of emission rate is plotted to show the predominence of smaller 
TABLE 1. Annuel wind Soeed, wind Direction, and stability Jaine Frequeney summary for the Mining Area.

SIND

SPEED

ATMISPHERIC

STABILITY

STABLE

O TO 3 NIGHT NEUTRAL OAY NEUTRAL SLT UNSTABLE VUSTABLE

STABLE

4 TO O NIGHT NEUTRAL OAY NEUTRAL SLT UNSTAALE UVSTABLE
V UNSTABLE

ST $\triangle B L E$

7 TO 10 NIGHI NEUTRAL OAY NEUTIRAL UNSTARLE $\checkmark$ UNSTASLE

STABLE

11 TO 16 NIGHT NEUTRAL OAY NEUTRAL SLT UNSTAALE UNSTAGLE $\checkmark$ UNSTABLE

17 TO IT NTAHLE NIGHT NEIJTRAL DAY NEUTRAL SLT UNSTAaLE UNS IA GLE

STABLE

OVER 21 NIGYT MEUTRAL DAY NEUTRAL
SILT UNSTABLE UNSTABLE $\checkmark$ UNSTABLE

tutal STABLE NIGHT NEIJPRAL DAY NEUTRAL SUSTASLE J'VSTASLE
WINO DIRECIION

N NNE NE ENE E ESE SE SSE S SSN SW WSN W WNW NW NNW CALM

TOTAL

$\begin{array}{lllllllllllllllllll}1.08 & 0.84 & 0.88 & 0.74 & 0.01 & 0.60 & 0.57 & 0.65 & 0.86 & 0.59 & 0.61 & 0.74 & 1.32 & 1.08 & 1.33 & 1.01 & 0.26\end{array}$

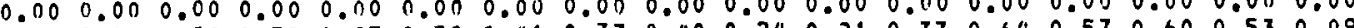

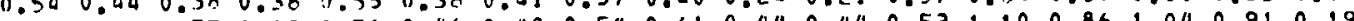

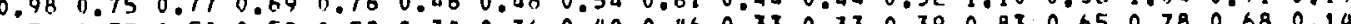

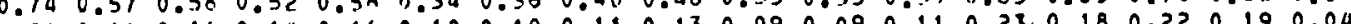
$\begin{array}{lllllllllllllllllll}0.21 & 0.16 & 0.16 & 0.14 & 0.16 & 0.10 & 0.10 & 0.11 & 0.13 & 0.09 & 0.09 & 0.11 & 0.23 & 0.18 & 0.22 & 0.19 & 0.04\end{array}$ $\begin{array}{lllllllllllllllllll}0.63 & 0.45 & 0.26 & 0.25 & 0.39 & 0.23 & 0.30 & 0.50 & 0.76 & 0.44 & 0.45 & 0.50 & 1.12 & 0.77 & 0.70 & 0.56 & 0.11\end{array}$ $0.00 \quad 0.00 \quad 0.000 .00 \quad 0.00 \quad 0.00 \quad 0.000 .00 \quad 0.00 \quad 0.000 .000 .00 \quad 0.000 .00$ $\begin{array}{lllllllllllllllll}0.30 & 0.19 & 0.07 & 0.07 & 0.17 & 0.09 & 0.18 & 0.23 & 0.33 & 0.22 & 0.23 & 0.21 & 0.59 & 0.36 & 0.28 & 0.20 & 0.06\end{array}$

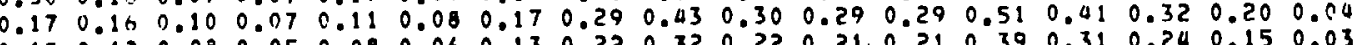

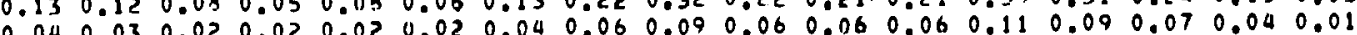
$\begin{array}{llllllllllllllllll}0.24 & 0.17 & 0.04 & 0.06 & 0.08 & 0.04 & 0.09 & 0.10 & 0.26 & 0.23 & 0.21 & 0.25 & 0.56 & 0.28 & 0.25 & 0.20 & 0.03\end{array}$

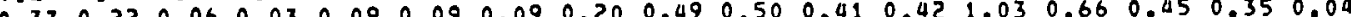

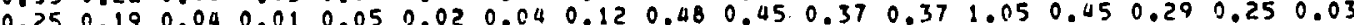

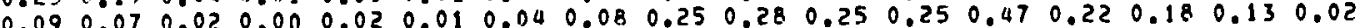
0.070 .060 .020 .000 .010 .010 .030 .060 .190 .210 .190 .190 .350 .160 .140 .100 .02

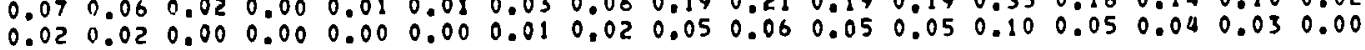
$0.000 .00 \quad 0.00 \quad 0.00 \quad 0.000 .00 \quad 0.00 \quad 0.00 \quad 0.00 \quad 0.00 \quad 0.00 \quad 0.00 \quad 0.00 \quad 0.00 \quad 0.000 .00 \quad 0.00$

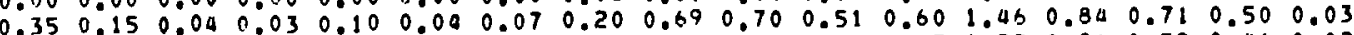
$\begin{array}{lllllllllllllllll}0.25 & 0.13 & 0.01 & 0.00 & 0.02 & 0.03 & 0.02 & 0.07 & 0.66 & 0.70 & 0.50 & 0.55 & 1.52 & 0.86 & 0.52 & 0.46 & 0.02\end{array}$

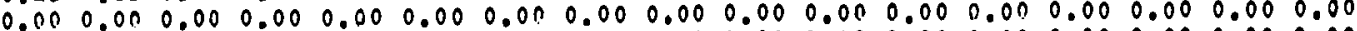

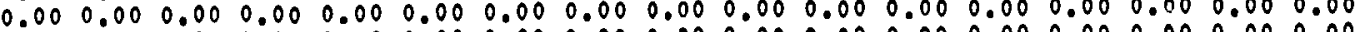
$0.000 .00 \quad 0.00 \quad 0.00 \quad 0.00 \quad 0.00 \quad 0.00 \quad 0.00 \quad 0.00 \quad 0.00 \quad 0.00 \quad 0.00 \quad 0.00 \quad 0.000 .00 \quad 0.00 \quad 0.00$

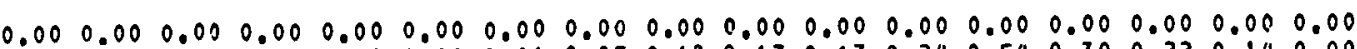
$\begin{array}{lllllllllllllllll}0.07 & 0.02 & 0.00 & 0.00 & 0.02 & 0.00 & 0.01 & 0.05 & 0.18 & 0.17 & 0.17 & 0.24 & 0.54 & 0.30 & 0.22 & 0.14 & 0.00\end{array}$

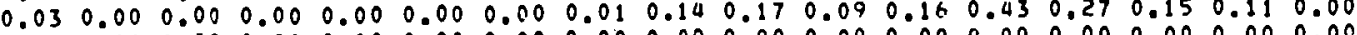

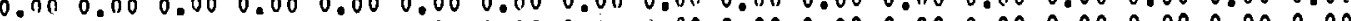

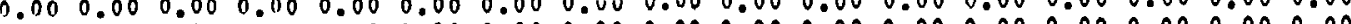
$0.00 \quad 0.00 \quad 0.00 \quad 0.00 \quad 0.00 \quad 0.00 \quad 0.00 \quad 0.000 .00 \quad 0.00 \quad 0.00 \quad 0.00 \quad 0.000 .000 .000 .000 .00$

$0.000 .00 \quad 0.00 \quad 0.00 \quad 0.000 .00 \quad 0.000 .000 .00 \quad 0.00 \quad 0.00 \quad 0.00 \quad 0.00 \quad 0.00 \quad 0.00 \quad 0.00 \quad 0.00$

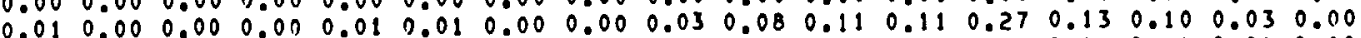

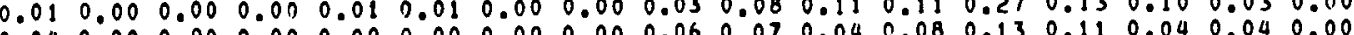

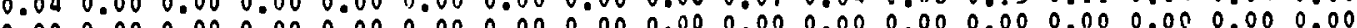

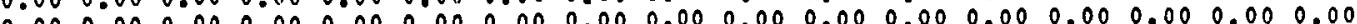
$0.000 .000 .000 .000 .0000 .000 .000 .000 .00 \quad 0.000 .00 \quad 0.00 \quad 0.00 \quad 0.000 .00 \quad 0.00 \quad 0.00$

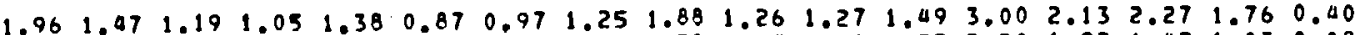
$1.961 .071 .191 .051 .380 .870 .97 \quad 1.251 .391 .451 .271 .4373 .301 .931 .471 .03 \quad 0.08$

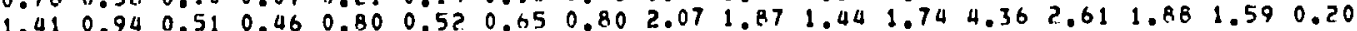

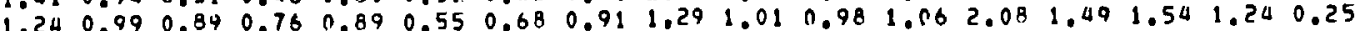

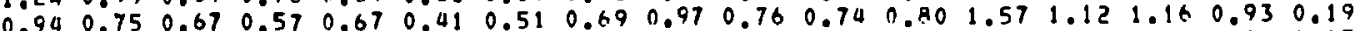

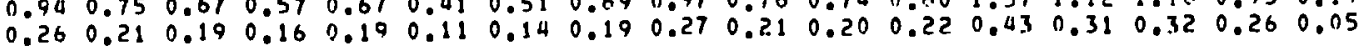

14.08

0.00

11.52

11.5

2.40

3.44

3.00

3.94

0.82

3.10

5.4

4.45

0.50

0.00

7.03
6.35

0.00

0.00

0.00

2.1

1.58

0.00

0.00

0.00

0.90

0.00
0.00
0.00

25.61

15.51
23.85

17.85

13.45
3.72

MASED DN OATA FRTM DFFICE OF RADIATION

OPERANS EPA, LAS VEGAS PUV, NIJV 1978 to DCT 1979.

values ere expreased in percentage of totel observations. 
Table 2. COMPARISONS OF ONSITE STABILITY WITH OTHER STAR REGIONAL DATA

\begin{tabular}{|c|c|c|c|c|c|c|}
\hline Station & \multicolumn{6}{|c|}{ Percentage Total Occurrence in Stability Groups } \\
\hline & $\begin{array}{c}\text { Very } \\
\text { Unstable }\end{array}$ & Unstable & $\begin{array}{l}\text { Slightly } \\
\text { Unstable }\end{array}$ & $\begin{array}{c}\text { Day } \\
\text { Neutral }\end{array}$ & $\begin{array}{c}\text { Night } \\
\text { Neutral } \\
\end{array}$ & Stable \\
\hline Onsite & $3.72 \%$ & 13.45 & 17.85 & 23.85 & 15.51 & 25.61 \\
\hline $25 \mathrm{~km}$ South & 2.58 & 9.32 & 12.37 & 30.69 & 16.80 & 28.17 \\
\hline $90 \mathrm{~km}$ West & 0.37 & 6.60 & 10.5 & $48.033^{7}$ & -- & 32.92 \\
\hline
\end{tabular}

${ }^{1}$ Single neutral stability value applies to both neutral classes.

Table 3. NUMBER OF MINE VENTS SAMPLED

\begin{tabular}{lrr} 
& Fall & Spring \\
\cline { 2 - 3 } & $\frac{1978}{70}$ & $\frac{1979}{104}$ \\
Sampled & 3 & 2 \\
Zero Value & 41 & $\frac{8}{114}$ \\
Missed & $\frac{41}{114}$ &
\end{tabular}




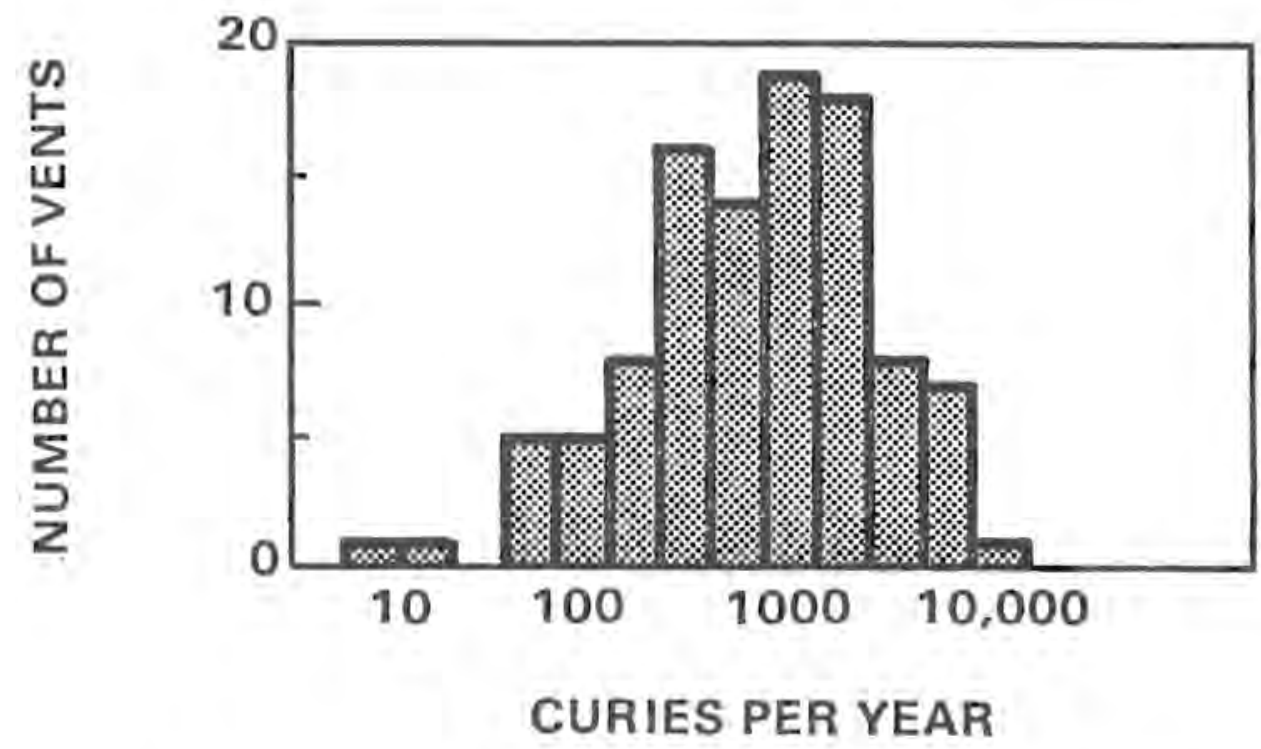

FIGURE 2. FREQUENCY PLOT OF MINE VENT SOURCE TERMS FOR SPRING 1979 DATA

sources. The distribution is approximately log-normal with a geometric mean emission rate of about $500 \mathrm{Ci} / \mathrm{yr}$. The arithmetic average is $1090 \mathrm{Ci} / \mathrm{yr}$.

Three active and one inactive uranium mills are found within a $20 \mathrm{~km}$ radius of the mining area and are located as shown in Figure 1. Each mill has one or more tailings piles which represent the major ${ }^{222} \mathrm{Rn}$ sources for the mil1 operations. Radon emissions are a function of the areal extent of the piles and the condition and type of cover over the pile. Data on active and inactive tailings pile exhalation rates per unit area are available for some mills (Silker 1979 and Momeni 1979). Published estimates of the areal extent of both active and inactive piles that were unstabilized during the vent sampling periods are also available. Annual emission values are calculated by multiplying the pile area by 365 days/year and by the measured daily exhalation rate where available or the rate measured for a similar pile. Table 4 shows the calculated annual emissions, pile areas and exhalation rates. 
Table 4. TAILINGS PILE SOURCE TERMS

\begin{tabular}{|c|c|c|c|}
\hline Mill & $\begin{array}{l}\text { Radon } \\
\text { Exhalation } \\
\text { Rates } \\
\text { Ci } / \text { day } / \mathrm{km}^{2} \\
\end{array}$ & $\begin{array}{c}\text { Approximate } \\
\text { Area } \\
\mathrm{km}^{2} \\
\end{array}$ & $\begin{array}{c}\text { Approximate } \\
\text { Radon } \\
\text { Curies/yr } \\
\end{array}$ \\
\hline A - inactive & $25^{\mathrm{a}}$ & $0.37^{f}$ & 3400 \\
\hline B - active & $7.1^{b}$ & $1.1^{\mathrm{g}}$ & 2800 \\
\hline C - active & $7^{\mathrm{C}}$ & $0.8^{h}$ & 2000 \\
\hline D - active & $8^{d}$ & $0.92^{i}$ & 2700 \\
\hline$D$ - inactive & $24^{\mathrm{e}}$ & $0.3^{j}$ & 2600 \\
\hline
\end{tabular}

a Average of measurements at three other inactive piles. Momeni (1979 pg. 6) measured average values of 35.9 and $15.1 \mathrm{Ci} /$ day $/ \mathrm{km}^{2}$ at two piles. At another, Silker (1979, see e below) measured a rate of $24 \mathrm{Ci} / \mathrm{day} / \mathrm{km}^{2}$.

b Silker (1979, pg. 48)

c Silker (1979, pg. 2) an average measured at two other active piles.

d Silker (1979, pg. 47)

e Silker (1979, pg. 49) measured an average exhalation of 500 atoms $/ \mathrm{cm}^{2} / \mathrm{sec}$ or $24 \mathrm{Ci} /$ day $/ \mathrm{km}^{2}$

$\frac{500 \text { a toms }}{\mathrm{cm}^{2} \mathrm{sec}} \times \frac{222 \mathrm{Rn} \lambda\left(\mathrm{min}^{-1}\right) \mathrm{Ci}}{2.22 \times 10^{12} \frac{\text { disintegration }}{\mathrm{min}^{1}}} \times \frac{86,400 \mathrm{sec}}{\text { day }} \times \frac{10^{10} \mathrm{~cm}^{2}}{\mathrm{~km}^{2}}=24 \mathrm{Ci} / \mathrm{day} / \mathrm{km}^{2}$ $222_{\mathrm{Rn \lambda}}=1.26 \times 10^{-4} \mathrm{~min}^{-1}$

f Perkins (1979, pg. 122)

g Silker (1979, pg. 6)

h Momeni (1979, pg. 1). The two inactive piles at this mill had been stabilized with clay by the time of vent sampling.

i Silker (1979, pg. 4)

j Silker (1979, pg. 4) 
Location and Magnitude of Sources

The intensive mining area identified in Figure 1 is replotted in Figure 3 with the locations of the vents marked by map identification numbers beside solid dots. Mill tailings piles $A$ and $B$ also are in the area covered by figure 3 .

The location of the mine vent sources is accomplished through a combination of aerial photos, published maps, reports and maps supplied by mine operators. The worst case location errors are estimated to be up to $0.35 \mathrm{~km}$. Most vents are located more accurately than this worst case value, particularly in terms of the vent separation distances. The average error is about $0.12 \mathrm{~km}$ for absolute vent location. The location of the mill tailings piles are obtained in the same manner. The accuracy of location of these is the $0.02 \mathrm{~km}$ resolution used in the definition of source locations.

The source terms derived for input to the dispersion model are 1 isted in Table 5. The map identification numbers for vents and locations in kilometers east and north refer to Figure 3. For the purposes of computation, mill tailings piles $A, B, C$, and D in Figures 1 and 2 are assigned in Table 5 "map" numbers 120, 121,122 and 123 respectively. These occur as emission rank numbers, 10, 12 , 20 and 4.

The emission rates for the vents are derived primarily from the more complete spring campaign data. Vents missed in the spring campaign are given the emission rate from the fal1. The three possible missed vents are approximated with the geometric mean emission rate of about $500 \mathrm{Ci} / \mathrm{yr}$. The mill tailings emissions are from Table 4. These consist of 117 vents and 4 mills of the former, uncapped vents consist of 114 sources.

\section{Receptor Selection}

Twelve receptor points are selected for studying the relative radon concentrations from the many sources. These are selected to represent monitoring stations and locations of human activity within the intensive mining area. These receptor points are plotted as open triangles on Figure 3 . Table 6 contains a summary of receptor points and their relative locations based on the kilometer distance scales on Figure 3. 


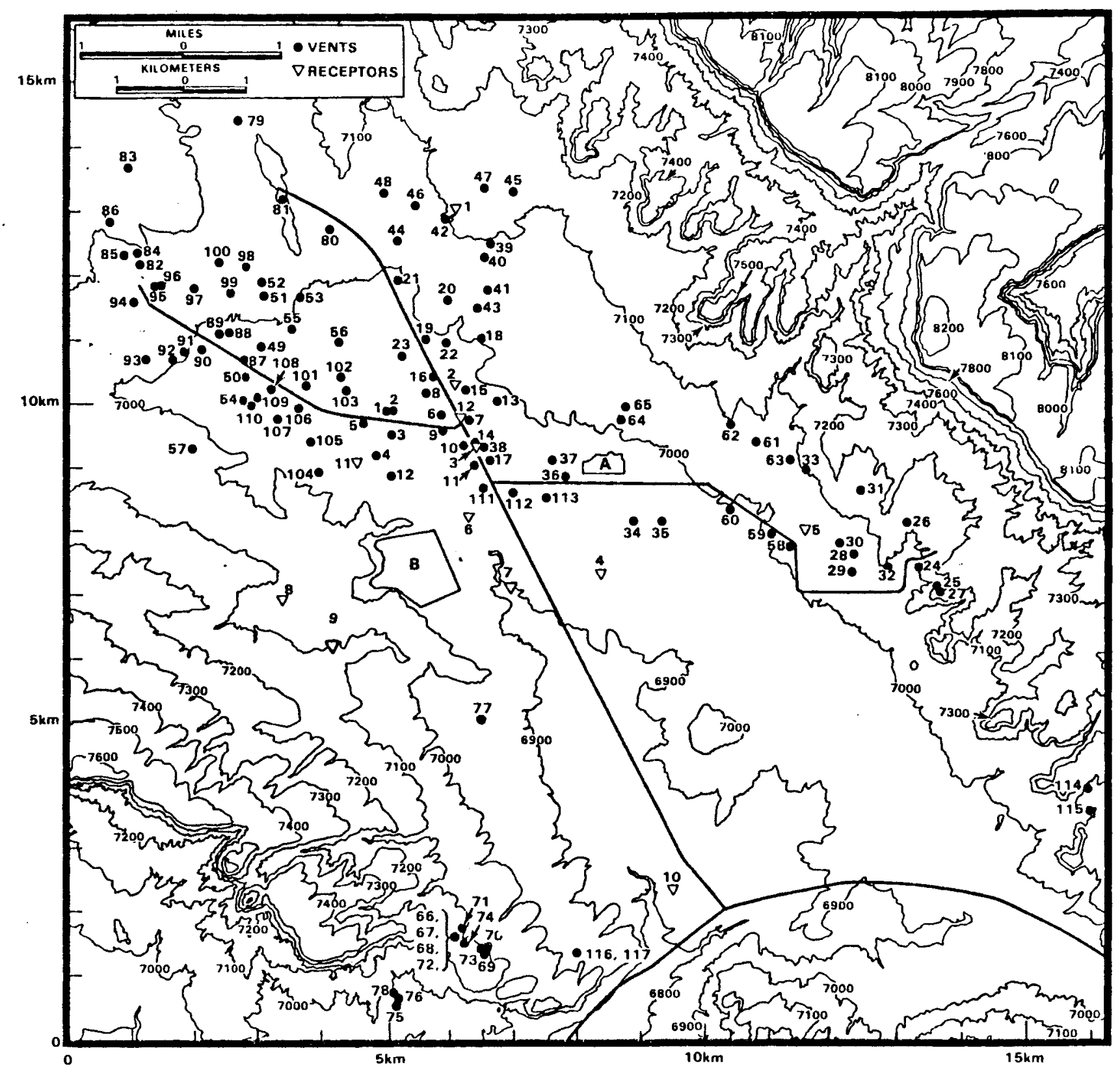

FIGURE 3. DETAILED MAP OF MINING AREA SHOWING SOURCE AND RECEPTOR POINTS 
Table 5. SOURCE TERMS FOR VENTS AND TAILINGS PILES

\begin{tabular}{|c|c|c|c|c|c|c|c|c|c|}
\hline RANK & $\begin{array}{c}\text { MAP } \\
\#\end{array}$ & $\begin{array}{c}x \\
(\mathrm{~km})\end{array}$ & $\begin{array}{c}Y^{2} \\
(k m)\end{array}$ & $\stackrel{\mathbb{Q}}{c i / y r}$ & RANK & $\begin{array}{c}\text { MAP } \\
*\end{array}$ & $\begin{array}{c}X \\
(k m)\end{array}$ & $\begin{array}{c}Y \\
(k m)\end{array}$ & $\stackrel{Q}{C_{1} / y_{r}}$ \\
\hline 1 & 94 & .97 & 11.41 & 8310 & 60 & 17 & 6.45 & 8.93 & 600 \\
\hline 2 & 99 & 2.48 & 11.53 & 5670 & 61 & 96 & 1.39 & 11.66 & 580 \\
\hline 3 & 110 & 2.83 & 9.82 & 5310 & 62 & 107 & 3.22 & 9.57 & 580 \\
\hline 4 & 123 & -5.46 & -6.82 & 5300 & 63 & 98 & 2.73 & 11.93 & 570 \\
\hline 5 & 82 & 1.07 & 11.98 & 5170 & 64 & 35 & 9.05 & 8.01 & 530 \\
\hline 6 & 105 & 3.72 & 9.23 & 4900 & 65 & 81 & 3.25 & 13.19 & 530 \\
\hline 7 & 87 & 2.73 & 10.49 & 4570 & 66 & 60 & 10.07 & B. 23 & 500 \\
\hline B & 95 & 1.26 & 11.58 & 4540 & 67 & 77 & 6.30 & 5.01 & 500 \\
\hline 9 & 25 & 13.17 & 7.04 & 3990 & 68 & 116 & 7.79 & 1.39 & 500 \\
\hline 10 & 120 & 8.08 & 8. 85 & 3400 & 69 & 117 & 7.94 & 1.49 & 500 \\
\hline 11 & 54 & 2.70 & 9.87 & 3180 & 70 & 80 & 3.99 & 12.45 & 460 \\
\hline 12 & 121 & 5.31 & 7.19 & 2800 & 71 & 50 & 2.73 & 10.24 & 450 \\
\hline 13 & 52 & 3.00 & 11.48 & 2770 & 72 & 7 & 6.05 & 9.57 & 430 \\
\hline 14 & 51 & 3.00 & 11.38 & 2510 & 73 & 91 & 1.81 & 10.64 & 420 \\
\hline 15 & 53 & 3.55 & 11.48 & 2490 & 74 & 103 & 4.24 & 9.99 & 410 \\
\hline 16 & 58 & 11.01 & 7.59 & 2330 & 75 & 46 & 5.06 & 12.87 & 380 \\
\hline 17 & 27 & 13.27 & 6.94 & 2160 & 76 & 22 & 5.78 & 10.76 & 350 \\
\hline 18 & 79 & 2.60 & 14.16 & 2100 & 77 & 36 & 7.59 & 8.83 & 350 \\
\hline 19 & 49 & 2.98 & 10.71 & 2050 & 78 & 14 & 6.20 & 9.23 & 340 \\
\hline 20 & 122 & -5.46 & -6.82 & 2000 & 79 & 73 & 6.18 & 1.44 & 340 \\
\hline 21 & 2 & 4.98 & 9.72 & 1950 & BO & 6 & 5.70 & 9.60 & 330 \\
\hline 22 & 29 & 11.93 & 7.27 & 1840 & 81 & 114 & 15.55 & 3.94 & 330 \\
\hline 23 & 40 & 6.35 & 12.05 & 1730 & 82 & 64 & B. 46 & 9.55 & 319 \\
\hline 24 & 9 & 5.70 & 9.37 & 1720 & 83 & 32 & 12.45 & 7.34 & 300 \\
\hline 25 & 日日 & 2.43 & 10.94 & 1690 & 84 & 10 & 4.71 & 9.15 & 290 \\
\hline 26 & 44 & 5.03 & 12.33 & 1680 & 85 & 61 & 10.49 & 9.23 & 280 \\
\hline 27 & 97 & 1.91 & 11.61 & 1560 & 86 & 100 & 2.31 & 12.03 & 270 \\
\hline 28 & 15 & 6.08 & 10.02 & 1500 & 87 & 34 & 8.63 & 8. 04 & 250 \\
\hline 29 & 8 & 5.48 & 9.94 & 1410 & 88 & 71 & 6.05 & 1.74 & 240 \\
\hline 30 & 113 & 7.32 & 8.41 & 1400 & 89 & 18 & 6.30 & 10.79 & 220 \\
\hline 31 & 43 & 6.25 & 11.28 & 1320 & 90 & 112 & 6.80 & 8.48 & 220 \\
\hline 32 & 21 & 5.03 & 11.73 & 1290 & 91 & 12 & 4.96 & 8.70 & 210 \\
\hline 33 & 56 & 4.14 & 10.76 & 1260 & 92 & 55 & 28.22 & 10.99 & 210 \\
\hline 34 & 1 & 4.86 & 9.72 & 1250 & 93 & 74 & 5.98 & 1.54 & 210 \\
\hline 35 & 4 & 4.71 & 9.05 & 1230 & 94 & 102 & 4.17 & 10.24 & 210 \\
\hline 36 & 108 & 3.15 & 10.07 & 1230 & 95 & 26 & 12.80 & 7.99 & 200 \\
\hline 37 & 30 & 11.76 & 7.69 & 1210 & 96 & 47 & 6.35 & 13.14 & 200 \\
\hline 38 & 86 & .60 & 12.60 & 1180 & 97 & 69 & 6.27 & 1.34 & 200 \\
\hline 39 & 62 & 10.07 & 9.50 & 1160 & 98 & 37 & 7.39 & 8.95 & 190 \\
\hline 40 & 28 & 11.95 & 7.54 & 1070 & 99 & 67 & 5.93 & 1.69 & 180 \\
\hline 41 & 42 & 5.75 & 12.65 & 1060 & 100 & 19 & 5.46 & 10.81 & 170 \\
\hline 42 & 106 & 28.35 & 9.77 & 940 & 101 & 70 & 6.32 & 1.44 & 170 \\
\hline 43 & 111 & 6.32 & 8.56 & 890 & 102 & 33 & 11.28 & 8.80 & 160 \\
\hline 44 & 104 & 3.84 & 8.90 & 880 & 103 & 109 & 2.93 & 9.92 & 160 \\
\hline 45 & 13 & 6.57 & 9.87 & 810 & 104 & 20 & 55.40 & 11.41 & 150 \\
\hline 46 & 38 & 6.35 & 9.13 & 810 & 105 & 66 & 5.93 & 1.69 & 140 \\
\hline 47 & 89 & 2.33 & 10.94 & 790 & 106 & 68 & 5.93 & 1.69 & 130 \\
\hline 48 & 5 & 4.64 & 9.57 & 770 & 107 & 23 & 5.11 & 10.54 & 100 \\
\hline 49 & 92 & 1.61 & 10.49 & 760 & 108 & 90 & 2.06 & 10.66 & 99 \\
\hline 50 & 59 & 10.69 & 7.81 & 750 & 109 & 57 & 1.81 & 9.25 & 96 \\
\hline 51 & 48 & 4.81 & 13.07 & 720 & 110 & 85 & .82 & 12.08 & 88 \\
\hline 52 & 115 & 15.57 & 3.57 & 720 & 111 & 78 & 4.98 & .79 & 87 \\
\hline 53 & 11 & 6.03 & 9. 88 & 660 & 112 & 39 & 6.45 & 12.28 & 72 \\
\hline 54 & 16 & 5.58 & 10.17 & 660 & 113 & 31 & 12.08 & 8.51 & 54 \\
\hline 55 & 24 & 12.95 & 7.34 & 650 & 114 & 75 & 5.03 & .60 & 52 \\
\hline 56 & 45 & 6.80 & 13.09 & 650 & 115 & 76 & 5.08 & .74 & 47 \\
\hline 57 & 65 & 8.56 & 9.75 & 643 & 116 & 83 & .87 & 13.44 & 40 \\
\hline 58 & 63 & 10.99 & 8.95 & 620 & 117 & 72 & 5.93 & 1.69 & 37 \\
\hline 59 & 101 & 3.65 & 10.07 & 620 & 118 & 93 & 1.19 & 10.54 & 10 \\
\hline
\end{tabular}

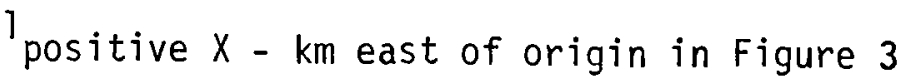

${ }^{2}$ positive $Y-\mathrm{km}$ north of oriqin in Fiqure 3 


\begin{tabular}{crr}
$\begin{array}{c}\text { Table 6. } \\
\begin{array}{c}\text { Receptor } \\
\text { ID }\end{array}\end{array}$ & $\begin{array}{c}\text { East } \\
(\mathrm{km})\end{array}$ & $\begin{array}{c}\text { North } \\
(\mathrm{km})\end{array}$ \\
\cline { 1 - 1 } 1 & 5.90 & 12.85 \\
2 & 5.90 & 10.14 \\
3 & 6.22 & 9.20 \\
4 & 8.13 & 7.24 \\
5 & 11.23 & 7.91 \\
6 & 6.13 & 8.11 \\
7 & 6.75 & 7.07 \\
8 & 3.27 & 6.84 \\
9 & 4.02 & 6.15 \\
10 & 9.25 & 2.26 \\
11 & 4.41 & 8.95 \\
12 & 6.00 & 9.62
\end{tabular}

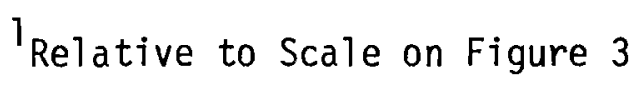


SECTION III

RESULTS

Average annual radon concentrations are computed using the source terms listed in Table 5. Detailed analysis of radon concentrations are made at the selected receptor points. In addition patterns of total computed concentrations are plotted.

\section{Receptor Concentrations}

The receptor point analysis provides both a basis for comparing computed radon values with monitored values and for studying the relative contributions of the many sources.

The total computed average radon concentration from all sources are given for each receptor in Table 7. Dividing the sources into two groups, vents and tailings piles, provides a means of comparison of the relative radon contribution. The last column in Table 7 contains the monitored radon values obtained over a period of six months.

The computed values do not include a background radon term. For comparison of the monitored and computed values, allowance should be made for a background value. Using the monitored values at monitoring stations located away from the intensive mining area gives an upper limit value for background. For receptors 8,9 , and 10 (Figure 3 ) the monitored radon values are $.63, .82$, and $1.25 \mathrm{pCi} / 1$ respectively. Allowing that the milling and mining operations may be contributing to these values, the range of possible background radon concentrations are taken to be from 0.0 up to about $0.5 \mathrm{pCi} / 1$.

The computed and monitored values are plotted in Figure 4. The agreement in Figure 4 shows that the computed concentrations from releases from mining and milling activities are of sufficient magnitude to be the major source of the monitored radon values. The fit of points is about as good as can be expected given the major modeling limitations for values adjacent to sources and the different time periods covered by computations and monitored values. 
Table 7. AVERAGE COMPUTED AND MONITORED RADON CONCENTRATIONS

\begin{tabular}{|c|c|c|c|c|}
\hline \multirow{2}{*}{$\begin{array}{l}\text { Receptor } \\
\text { Station } \\
\text { Map ID } \\
\end{array}$} & \multicolumn{3}{|c|}{$\begin{array}{l}\text { Annual Average Computed } \\
\text { Concentrations }\end{array}$} & \multirow{2}{*}{$\begin{array}{c}\text { Moni tored }^{\mathrm{a}} \\
\text { Concentrations } \\
\text { (six months) }\end{array}$} \\
\hline & $\begin{array}{l}\text { Mine } \\
\text { Vents }\end{array}$ & $\begin{array}{l}\text { Tailings } \\
\text { Piles } \\
\end{array}$ & $\begin{array}{c}\text { A11 } \\
\text { Sources }\end{array}$ & \\
\hline 1 & $1.8^{\mathrm{b}}$ & 0.03 & 1.8 & 0.94 \\
\hline 2 & 3.9 & 0.06 & 4.0 & 1.99 \\
\hline 3 & 6.0 & 0.11 & 6.1 & 3.14 \\
\hline 4 & 0.83 & 0.22 & 1.0 & 2.58 \\
\hline 5 & 1.8 & 0.07 & 1.8 & 1.77 \\
\hline 6 & 1.6 & 0.15 & 1.8 & 3.29 \\
\hline 7 & 0.89 & 0.25 & 1.1 & 2.67 \\
\hline 8 & 0.82 & 0.06 & 0.88 & 0.63 \\
\hline 9 & 0.63 & 0.08 & 0.70 & 0.82 \\
\hline 10 & 0.33 & 0.03 & 0.36 & 1.25 \\
\hline 11 & 3.3 & 0.07 & 3.4 & $\mathrm{c}$ \\
\hline 12 & 5.1 & 0.07 & 5.2 & c \\
\hline
\end{tabular}

a Preliminary data for April-Sept 1978 supplied, Radiation Protection Section, Environmental Improvement Division, State of New Mexico in "Status Report, Uranium Mine and Mill Tailings Study for the Grants Mineral Belt", January 1979

b All values expressed in $\mathrm{pCi} / \mathrm{l}$.

C Not a monitoring site. 


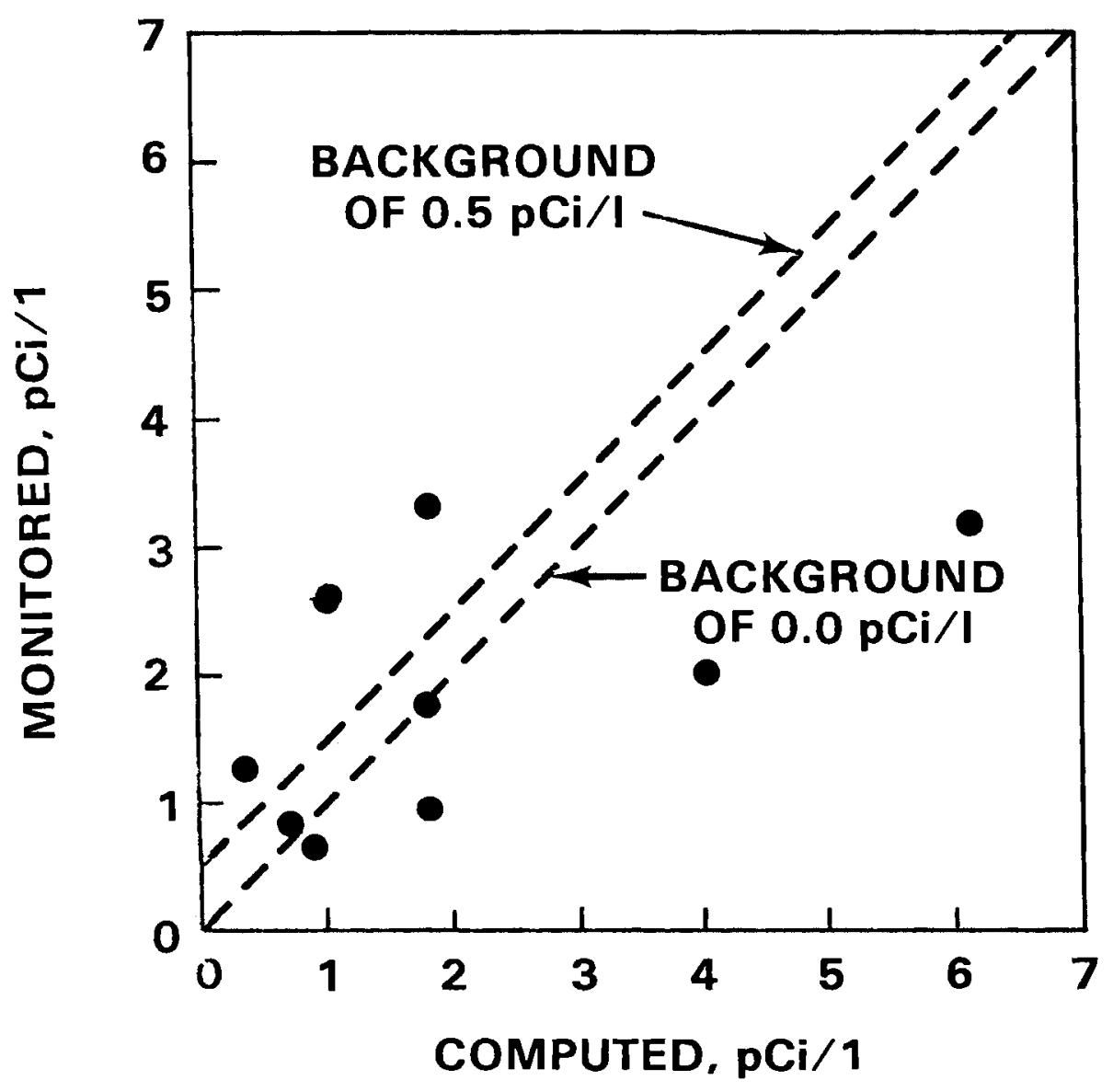

FIGURE 4. COMPARISON OF MONITORED AND COMPUTED RADON CONCENTRATIONS 
The consideration of background radon concentrations in the comparison of computed and monitored values is limited by the scatter and uncertainty in Figure 4. The $y$-intercept value of a best fit 1 ine would be the background value. For comparison lines with a $1: 1$ slopes are shown for the estimated range of background values $(0.0$ to $0.5 \mathrm{pCi} / 1)$. Both 1 ines fall within the scatter of points.

The contribution of each source to the concentration at the twelve receptor points is summarized in Appendix $A$ in two sets of tables. The first set containing the emissions ranked by size contains contributions for computed radon values ranked by source size (Table A.1 to A.12 for receptors 1 to 12 respectively). The first column contains emission rank numbers. The second column is map source numbers referring to Table 5 and Figure 3. (Note that tailings piles $A$ to $D$ are sources 120 to 123 , respectively.) Each table contains information for total mills, total vents, all sources, and each source in decending order by emission rate. The angle and distance from receptor to each source are given. The computed concentrations are given both as $\mathrm{pCi} / 1$ and as percentage of the total concentration from all sources. The last column is the cumulative percentage concentration. These tables show that for none of the receptor points are the largest emissions dominating the computed concentrations. Instead the total radon value contains significant contributions from multiple sources with a range of emission rates.

The sources that are contributing the largest fractions of computed radon are more clearly shown in Tables A.13 to A.24 for receptors 1 to 12 respectively. These tables have the results in the first set of tables reorganized in order of relative radon concentration contributions. This second set of tables shows that although several of the receptors have very close sources that contribute a large fraction of the radon concentration, in most cases the largest fraction of computed radon values are from many sources rather than one.

Computed Radon Concentration Patterns

All mine vent and tailings pile source terms are input to a grid output version of the dispersion model. Figure 5 shows the radon concentration patterns plotted over the map presented as Figure 1 . The radon values are plotted as lines of constant value. These lines are labeled in $\mathrm{pCi} / 1$ and occur at natural logrithm concentration spacings to allow display of many order of magnitude. 


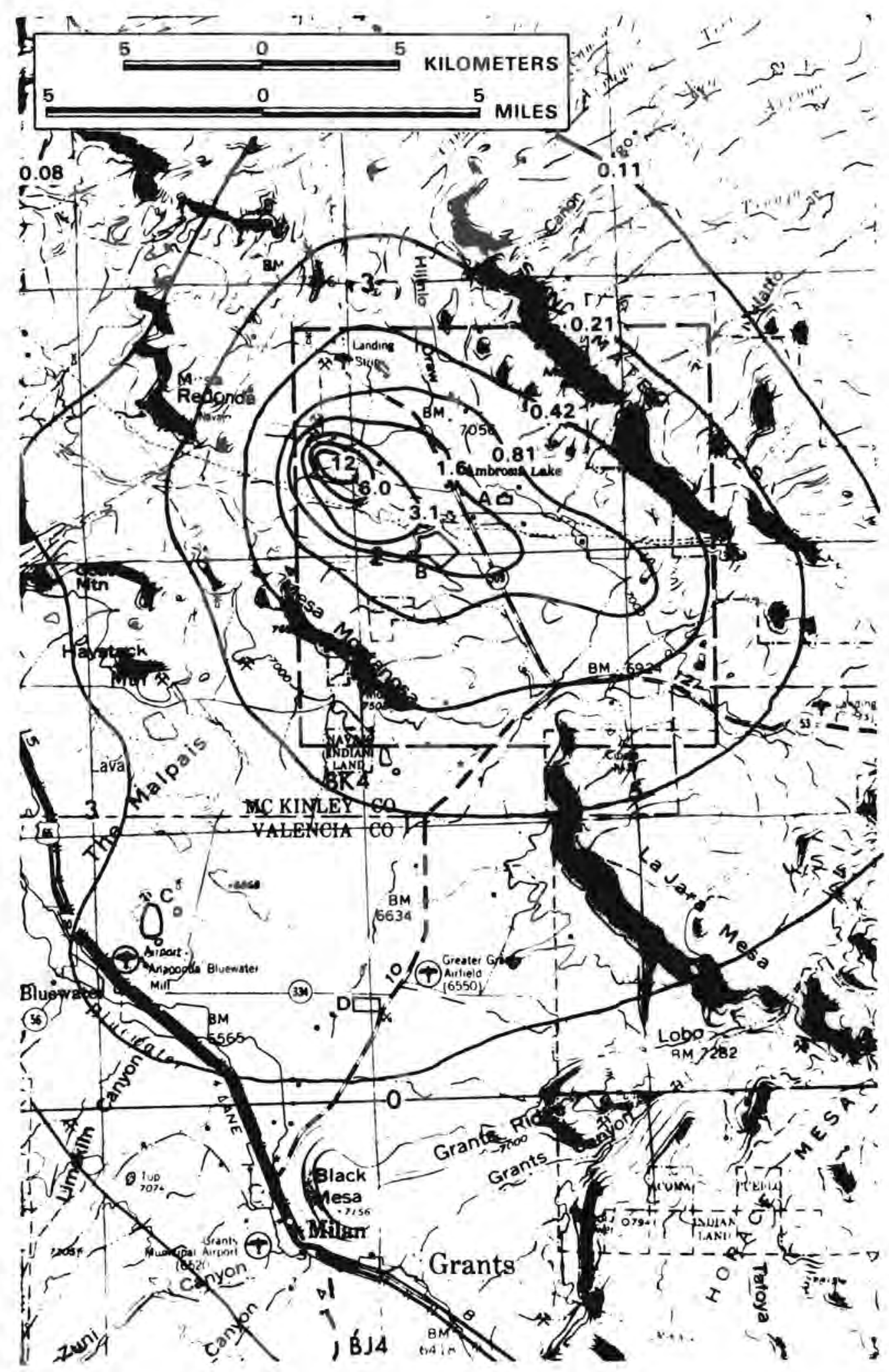

FIGURE 5. COMPUTED RADON CONCENTRATION MAP FOR REGION ISOPLETHS ARE IN $\mathrm{pCi} / \ell$ 
A detailed map of computed average annual radon concentrations for the intensive mining area is given in Figure 6 . The dashed area in Figure 5 is the area covered by Figure 6 . The influence of single vents and tailings piles are more evident in this figure. 


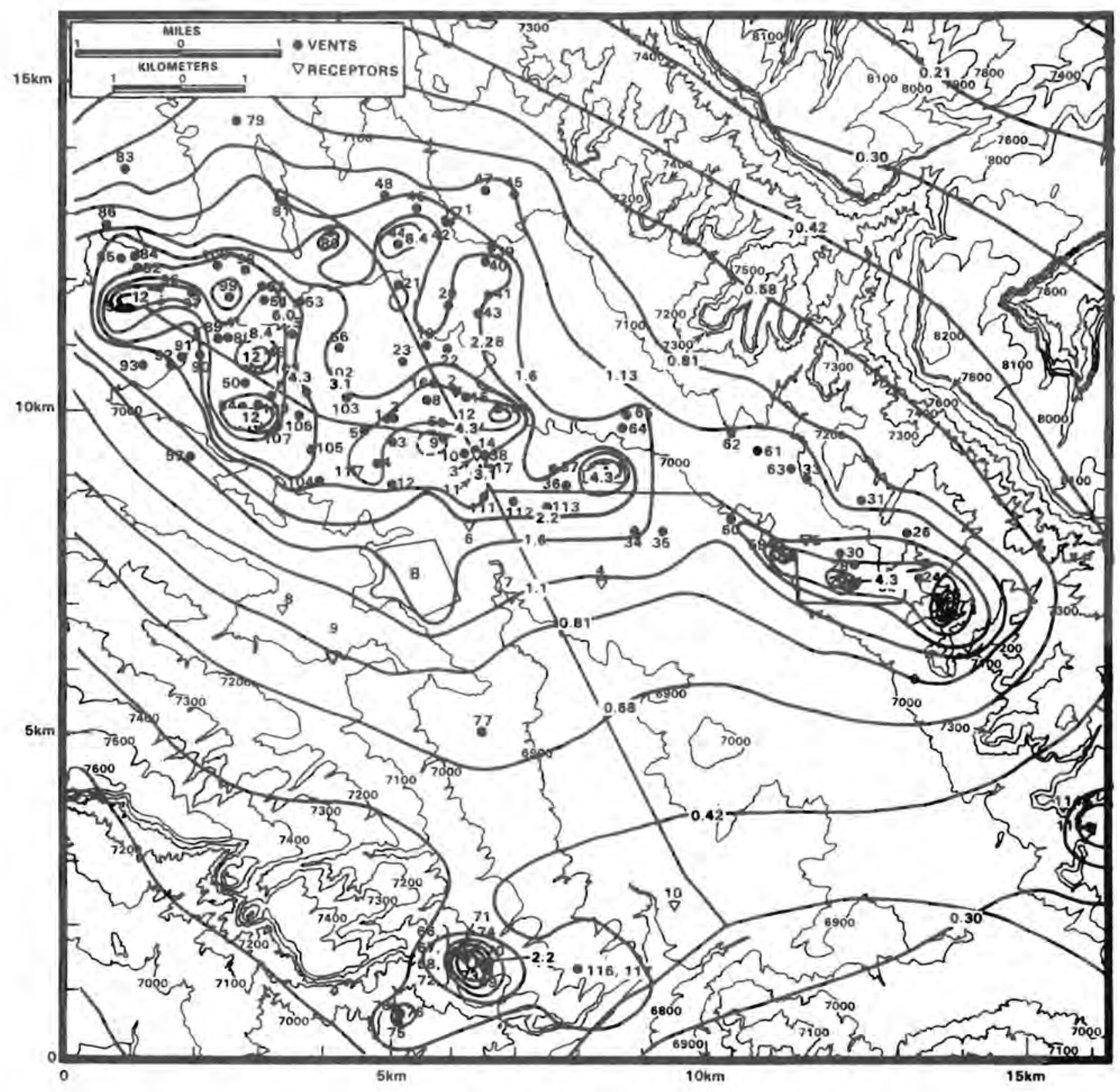

FIGURE 6. COMPUTED RADON CONCENTRATION MAP FOR INTENSIVE MINING AREA. ISOPLETHS ARE IN PCi/l 
SECTION IV

DISCUSSION AND CONCLUSIONS

The computed radon concentrations are of the same order of magnitude as concentrations measured at the receptor points. The major fraction of each of the computed concentrations are from many sources, rather than one. Table 8 summarizes the results in Tables A.1 to A.12 in terms of the number of sources in the region (starting with the largest) that account for 10 , 50 , and $90 \%$ of the computed radon value. The largest source contributors for each receptor are summarized in Table 9 . Tables 8 and 9 indicate that the closer sources, rather than the larger sources in the region tend to control the computed radon values.

The accuracy of the large fractional contributions of computed radon for several of the receptors is open to question from a modeling standpoint. Receptors particularly close to a source are marked with a star (*) in Table 9 . The uncertainty arises in two ways. First, the compuced concentrations will be very sensitive to the exact separation distances. These are on the order of the distance error estimated for location of sources in several cases. Second, the model does not adequately treat dispersion influences at these very close distances. For example, the concentrations will be a function of release vent size, orientation, plume rise, and local surface roughness elements (buildings, wa11s, trees, etc.). Computed radon concentrations for very close receptors and sources can only be considered as an indication of a large local concentration influence. With the possible exception of a distance error, most modeling limitations will overestimate concentrations computed at very close distances.

This discussion of the accuracy of radon concentrations applies only to the concentrations computed at close distances. As the distance of radon plume travel becomes greater, the effect of the local release point dispersion characteristics becomes progressively smaller. Also, uncertainty about the very close distance computations applies only to a fraction of about one third or less of the computed radon values. The rest of the fraction is contributed by multiple sources at distances appropriate to the modeling assumptions. 
Table 8. NUMBER OF LARGE SOURCES THAT ACCOUNT FOR 10, 50 AND 90\% OF THE COMPUTED RADON CONCENTRATIONS AT EACH RECEPTOR 1

\begin{tabular}{|c|c|c|c|}
\hline $\begin{array}{c}\text { Receptor } \\
\text { No. } \\
\end{array}$ & $10 \%$ & $50 \%$ & $90 \%$ \\
\hline 1 & 7 & 41 & 63 \\
\hline 2 & 7 & 28 & 59 \\
\hline 3 & 13 & 46 & 78 \\
\hline 4 & 6 & 23 & 69 \\
\hline 5 & 10 & 22 & 63 \\
\hline 6 & 6 & 30 & 67 \\
\hline 7 & 5 & 19 & 64 \\
\hline 8 & 3 & 12 & 58 \\
\hline 9 & 3 & 13 & 60 \\
\hline 10 & 3 & 23 & 78 \\
\hline 11 & 5 & 21 & 57 \\
\hline 12 & 11 & 31 & 76 \\
\hline
\end{tabular}

'Based on Appendix Tables A.1 to A.12. 
Table 9. SOURCES WITH THE LARGEST COMPUTED

CONCENTRATION AT EACH RECEPTOR

\begin{tabular}{|c|c|c|c|c|c|}
\hline $\begin{array}{l}\text { Map } \\
\text { Receptor } \\
\text { No. } \\
\end{array}$ & $\begin{array}{c}\text { Largest } \\
\text { Source } \\
\text { No. } \\
\end{array}$ & $\begin{array}{c}\text { Concen. } \\
(\%)\end{array}$ & $\begin{array}{c}\text { Emission } \\
\text { Rate } \\
\text { (Ci/yr) } \\
\end{array}$ & $\begin{array}{l}\text { Distance } \\
(\mathrm{m})\end{array}$ & $\begin{array}{c}\text { Emission } \\
\text { Rank } \\
\text { No. } \\
\end{array}$ \\
\hline $1^{*}$ & 42 & 36.3 & 1.060 & 248 & 41 \\
\hline $2^{\star}$ & 15 & 24.2 & 1500 & 213 & 28 \\
\hline $3^{*}$ & 14 & 33.7 & 340 & 100 & 78 \\
\hline 4 & 120 & 14.0 & 3440 & 1610 & 10 \\
\hline $5^{\star}$ & 58 & 34.1 & 2330 & 392 & 16 \\
\hline 6 & 111 & 10.0 & 890 & 488 & 43 \\
\hline 7 & 121 & 17.5 & 2800 & 1640 & 12 \\
\hline 8 & 105 & 12.2 & 4900 & 2420 & 6 \\
\hline 9 & 105 & 10.2 & 4900 & 3090 & 6 \\
\hline 10 & 117 & 4.4 & 500 & 1522 & 69 \\
\hline 11 & 105 & 21.9 & 4900 & 746 & 6 \\
\hline $12 *$ & 7 & 21.3 & 430 & 100 & 72 \\
\hline
\end{tabular}

Although, the computed and monitored values are of comparable magnitudes, the comparison is limited by the different time frames for these values and by modeling assumptions. A tendency occurs for the larger computed values to exceed corresponding monitored values. These also are computed values with a close source contributing a relatively large fraction. The comparison of monitored and computed values is improved when radon contributions from very close sources are excluded. This relates to the preceding discussion on computed radon values from very close sources.

The scatter in the concentration values precluded evaluation of background concentration from the plot of monitored and computed values. The points do occur in a pattern that is consistent with a background in the estimated range of 0.0 to $0.5 \rho \mathrm{Ci} / 1$.

The reiatively high radon concentrations are restricted to an area within and surrounding the mining and milling operations area. Average annual radon con- 
centrations approach the estimated background $(0.5 \rho \mathrm{Ci} / \mathrm{l})$ at distances of 5 to $10 \mathrm{~km}$ away from the intensive mining area. Very high concentrations are computed adjacent to the vents; these range up to $16 \mathrm{pCi} / 1$. The area nature of the tailings piles results in relatively smaller adjacent concentrations than for equivalent vent emission rates.

The receptor point analysis and the concentration maps both clearly demonstrate that the mine vents are the major influence on the computed radon concentrations. The tailing piles contribute to, but do not control the computed radon patterns. 


\section{SECTION $V$}

\section{REFERENCES}

A. D. Busse and J. R. Zimmerman. "User's Guide for the Climatological Dispersion Mode1," Publ. No. EPA-RA-73-024 (NTIS PB 227346/AS), Environmental Protection Agency, Research Triangle Park, North Carolina, December 1973.

T. Gedayloo, S. Barr, W. E. Clements and S. K. Wilson. "Summertime Nocturnal Drainage Flow in the San Mateo and Ambrosia Lake Air Sheds of the Grants Basin," Los Alamos Scientific Laboratory, New Mexico, LA-7628-MS, January 1979.

B. L. Perkins, An Overview of the New Mexico Uranium Industry, New Mexico Energy and Minerals Department, Santa Fe, New Mexico, January 1979.

M. H. Momeni, W. E, Kisieleski, S. Tyler, A. Zielen, Y. C. Yuanand and C. J. Roberts. "Radiological Impact of Uranium Tailings and Alternatives for Their Management, "Presented at the Health Physics Society Twelfth Midyear Topical Symposium on Low Level Radioactive Waste Management, February 1979. U. S. Environmental Protection Agency 520/3-27-002.

W. B. Silker and P. G. Heasler. Diffusion and Exhalation of Radon from Uranium Tailings, NUREG/CR-1138, PNL-3207, Pacific Northwest Laboratory, Richland, Washington, October 1979. 
APPENDIX A

TABLES OF COMPUTED RADON CONCENTRATIONS

AT SELECTED RECEPTOR POINTS 
TABLE A.1a. Computed Radon Concentration: at Receptor 1.

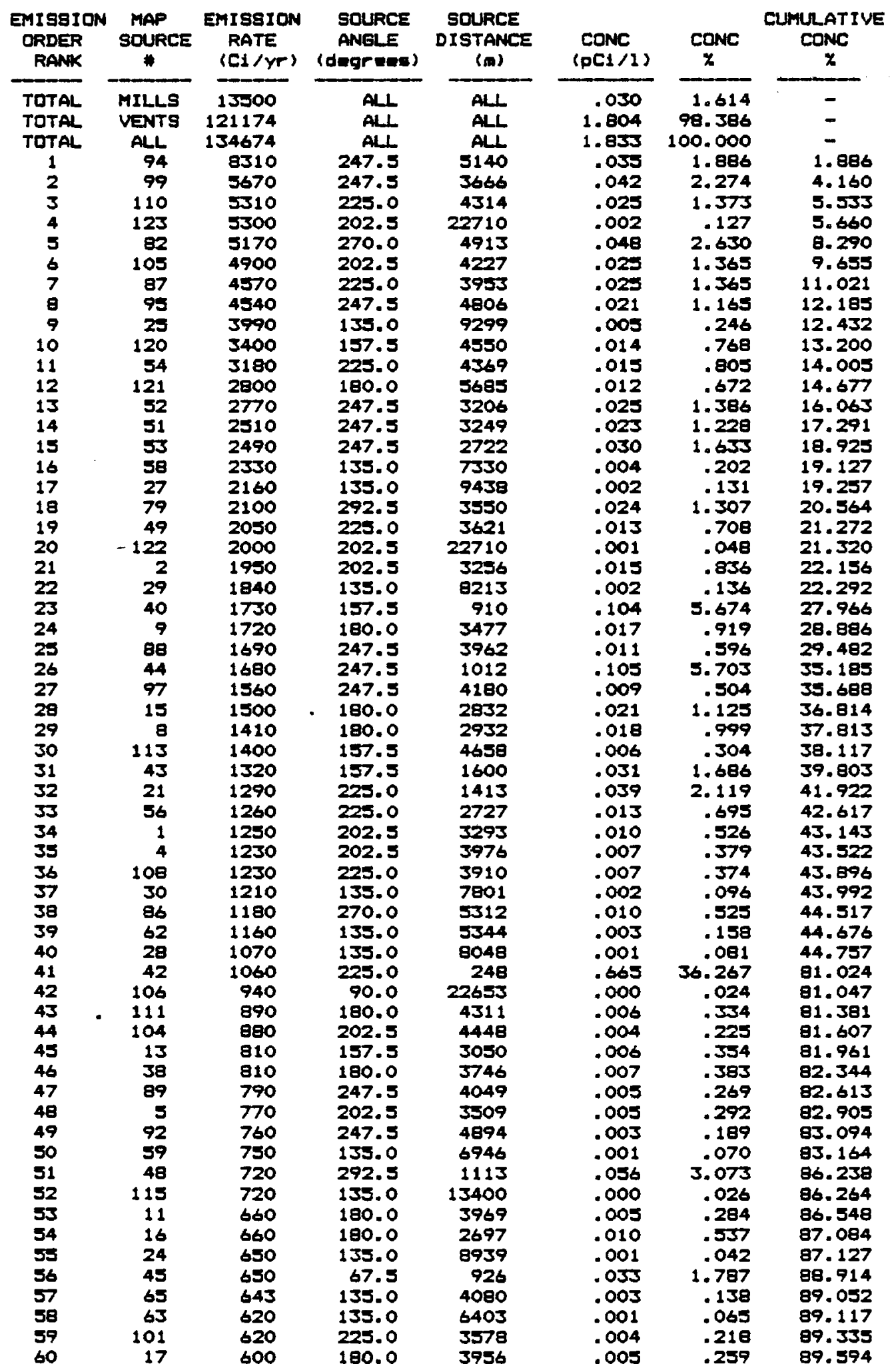


TABLE A.1b. Computed Radon Concentrations at Recoptor 1.

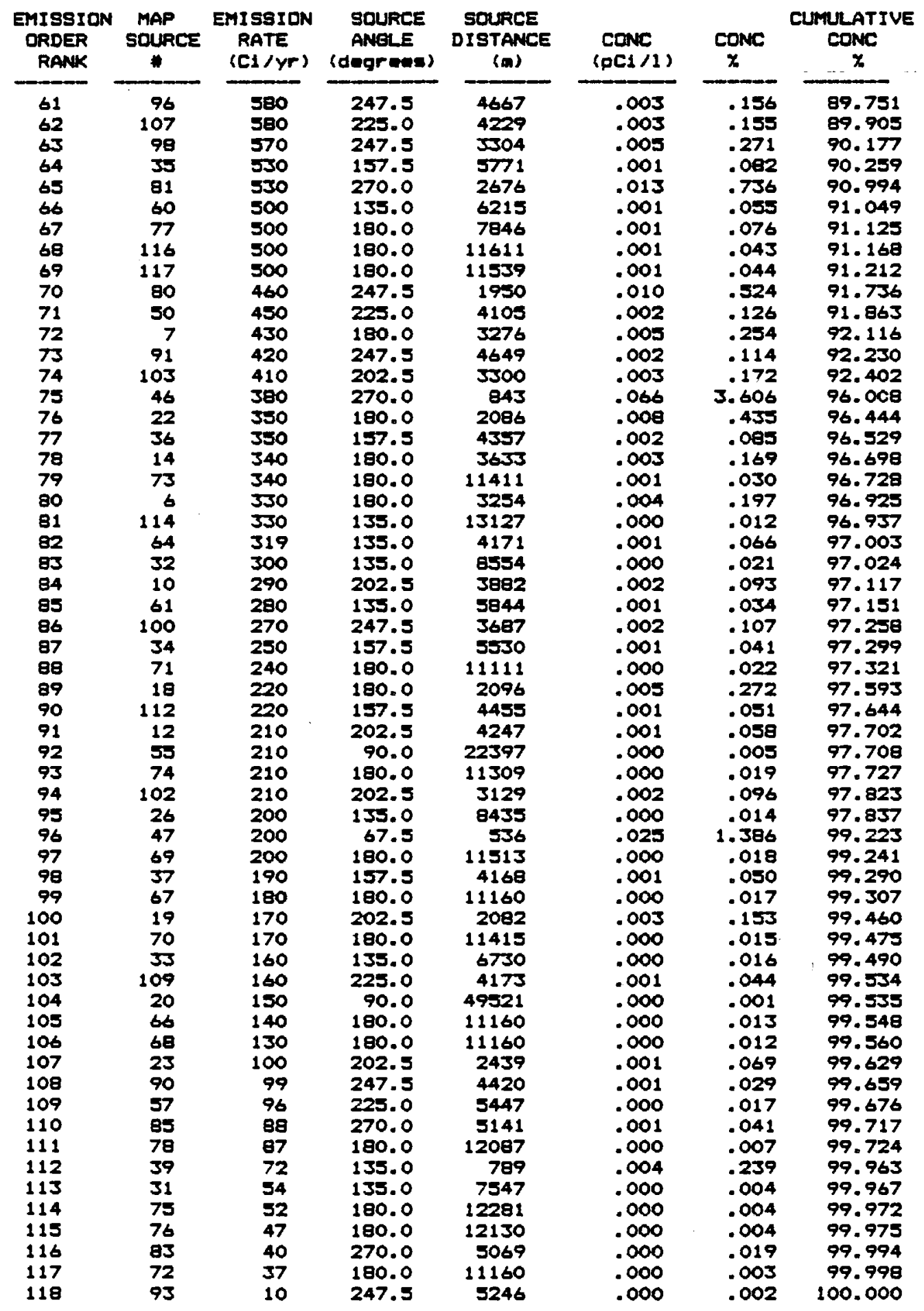


TAELE A.2a. : Computed Radon Concantrations at Receptor 2.

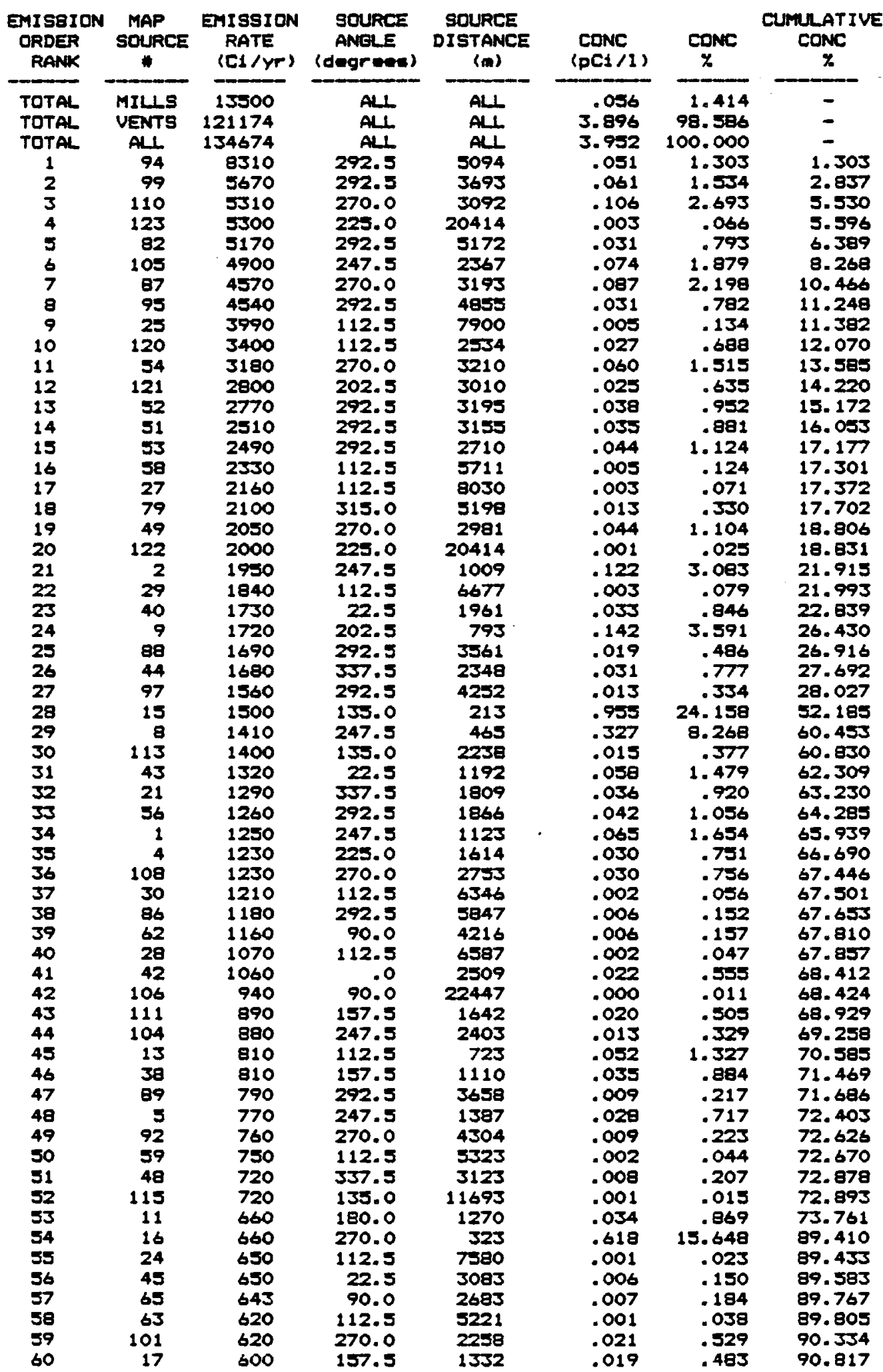


TABLE A.2b. Computed Radon Concentrations at Receptor 2.

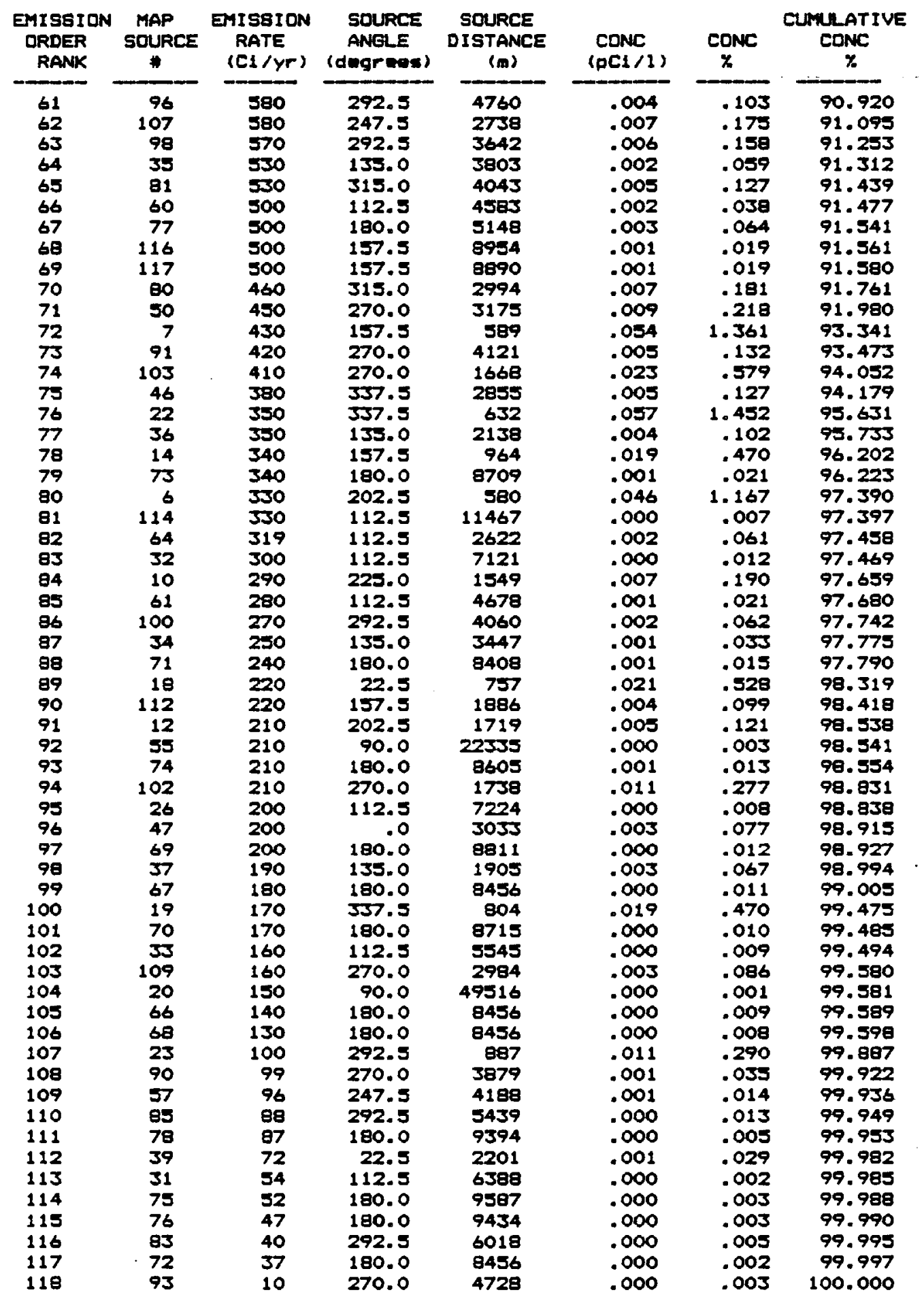


TABLE A.Ja. Computed Radon Concentrations at Rmemptor 3.

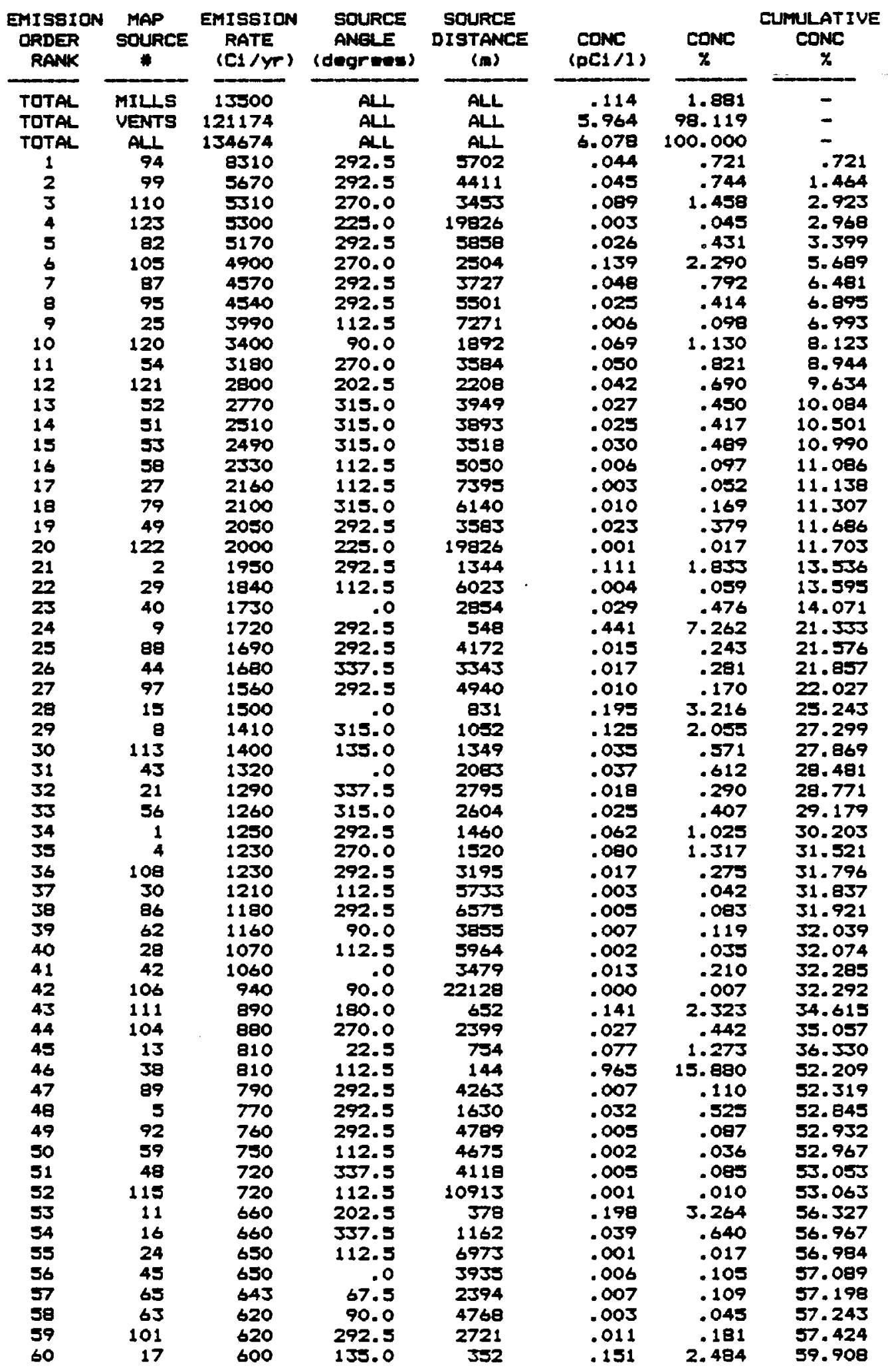


TABLE A.3b. Computad Radon Concentrations at Recaptor 3.

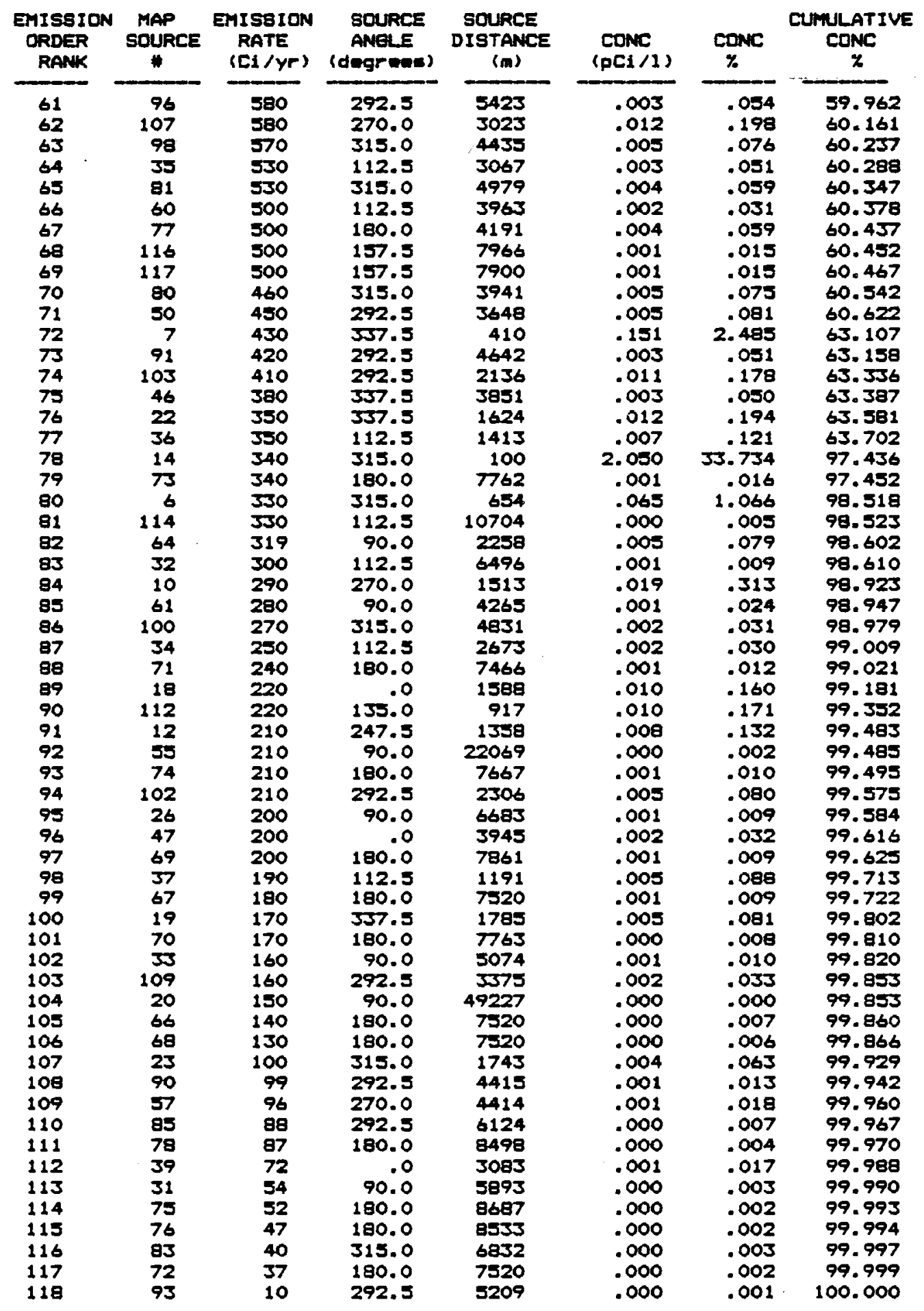


TABLE A.4a. Computed Radon Concentrations at Racuptor 4.

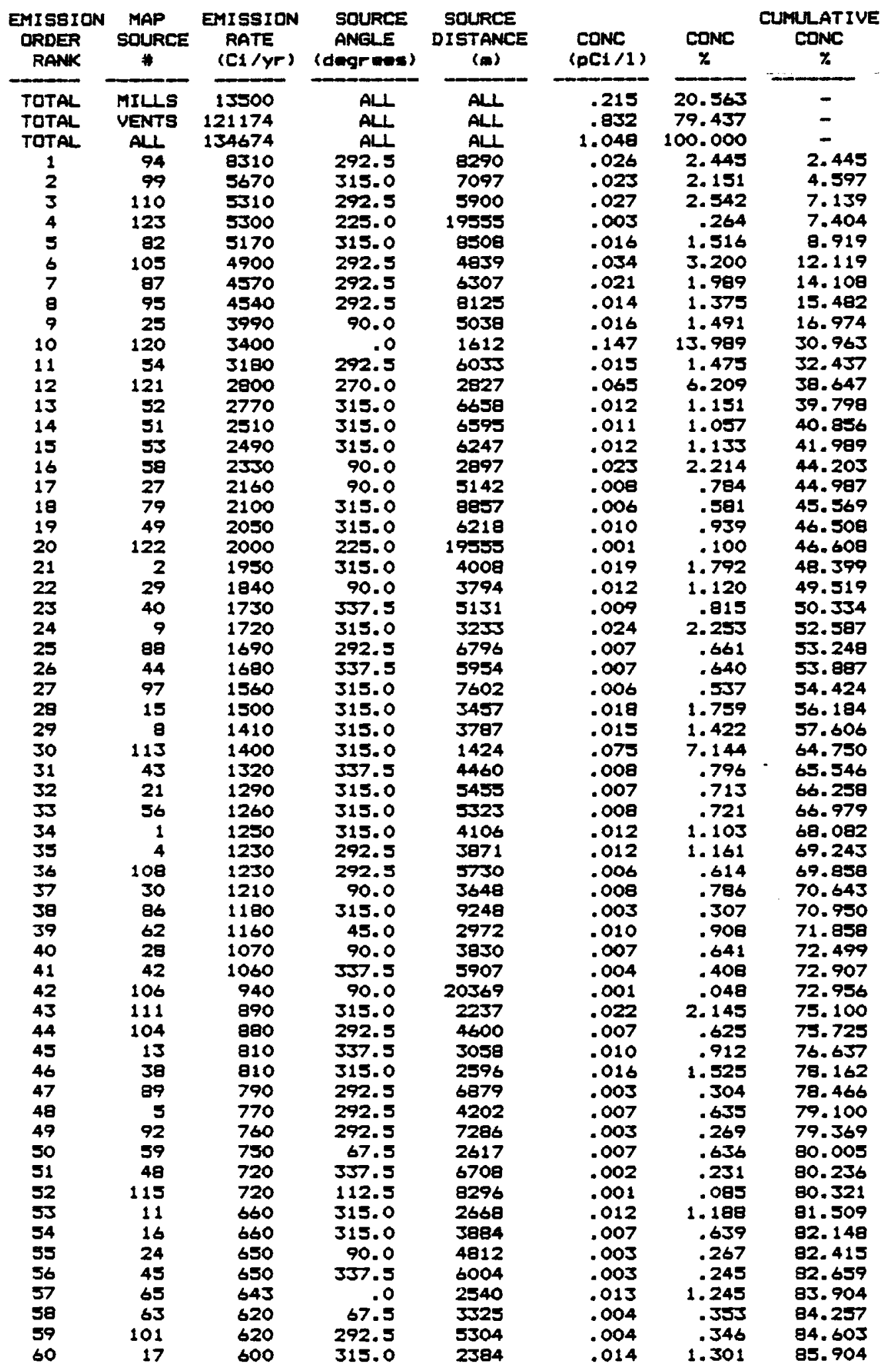


TABLE A.4b. Computad Radon Concentrations at Raceptor 4.

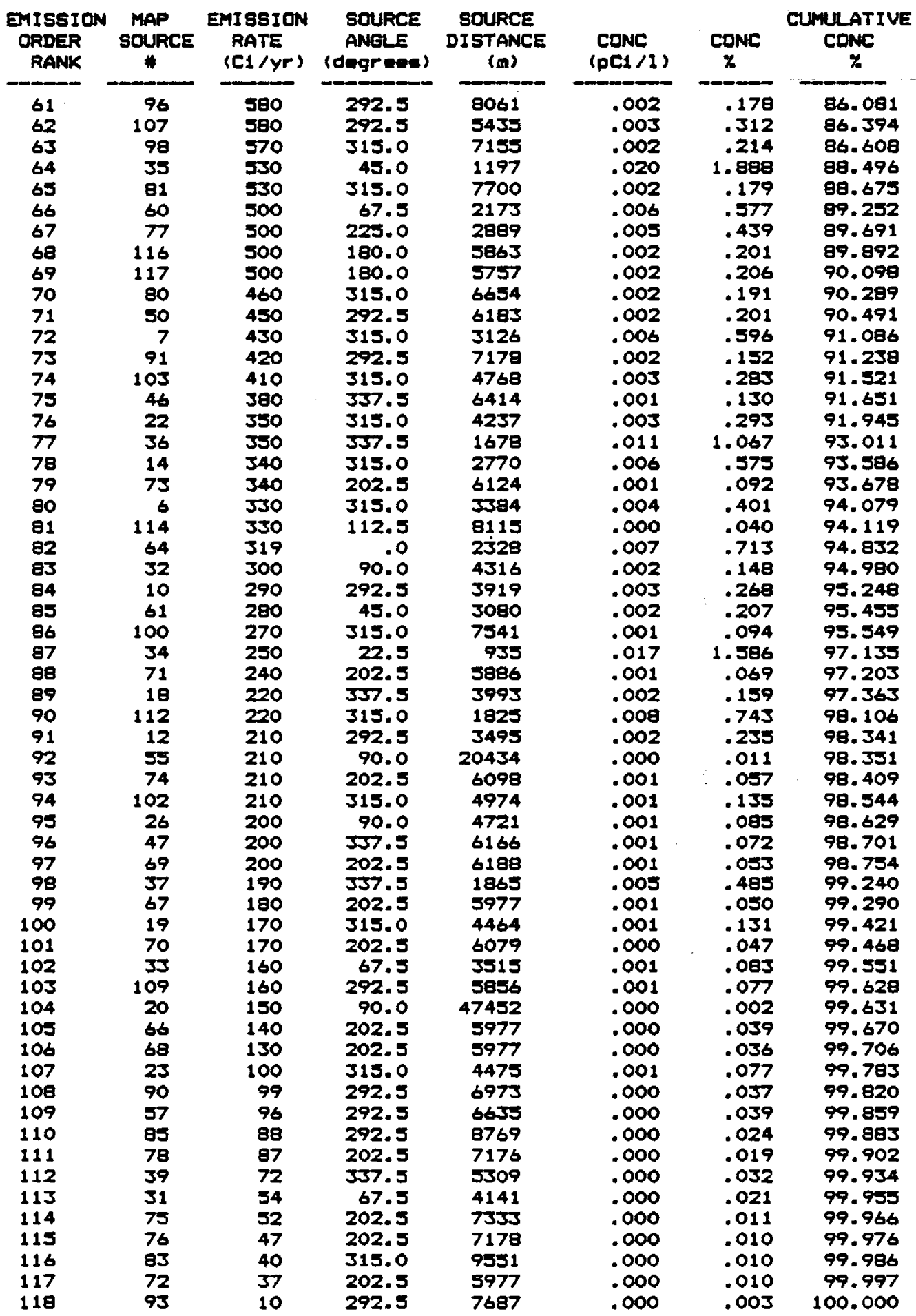


TABLE A.Sa. Computad Radon Concentratione at Roceptor 5.

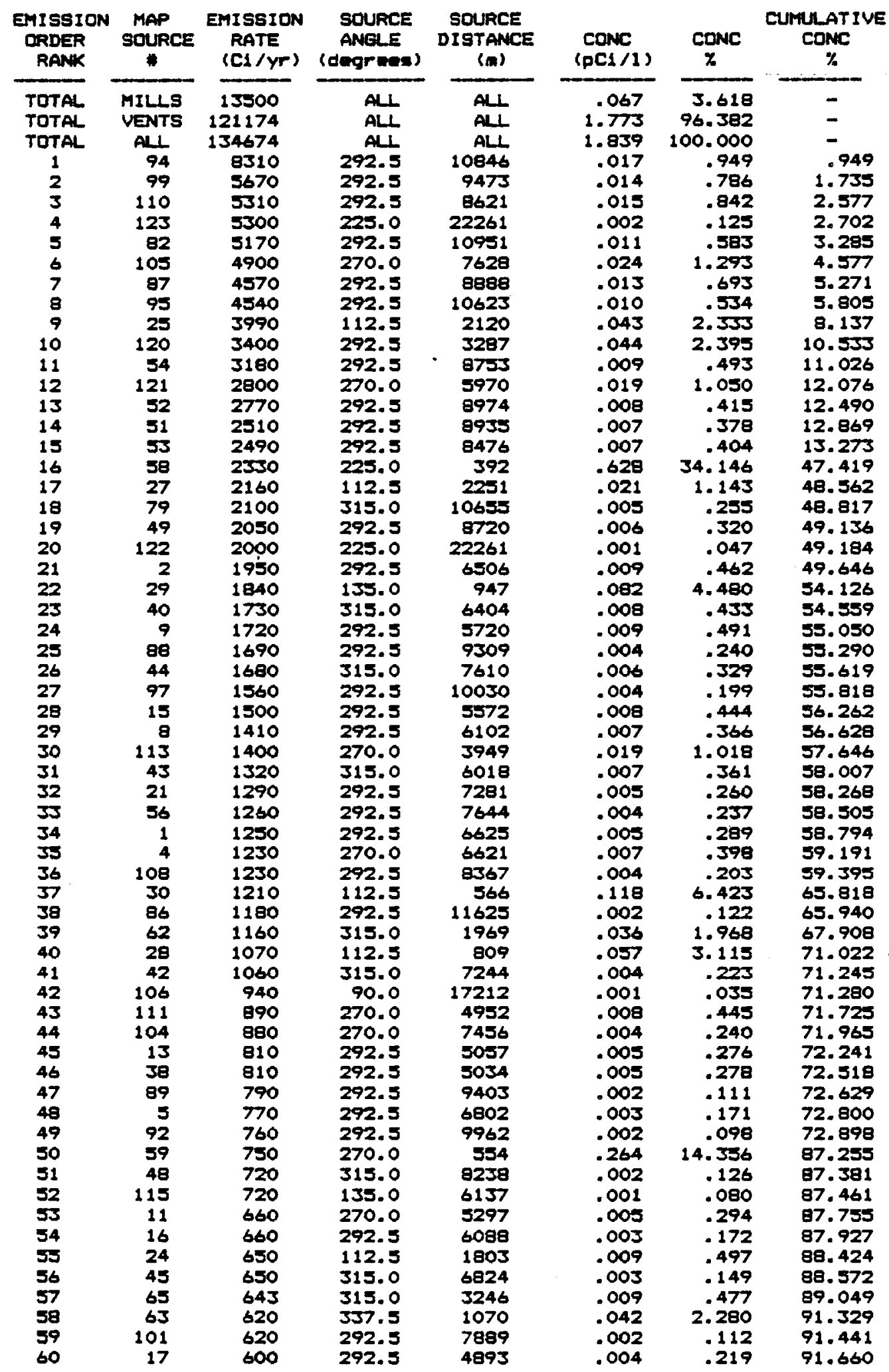


TABLE A.5b. Computed Radon Concentratione at Roceptor 5.

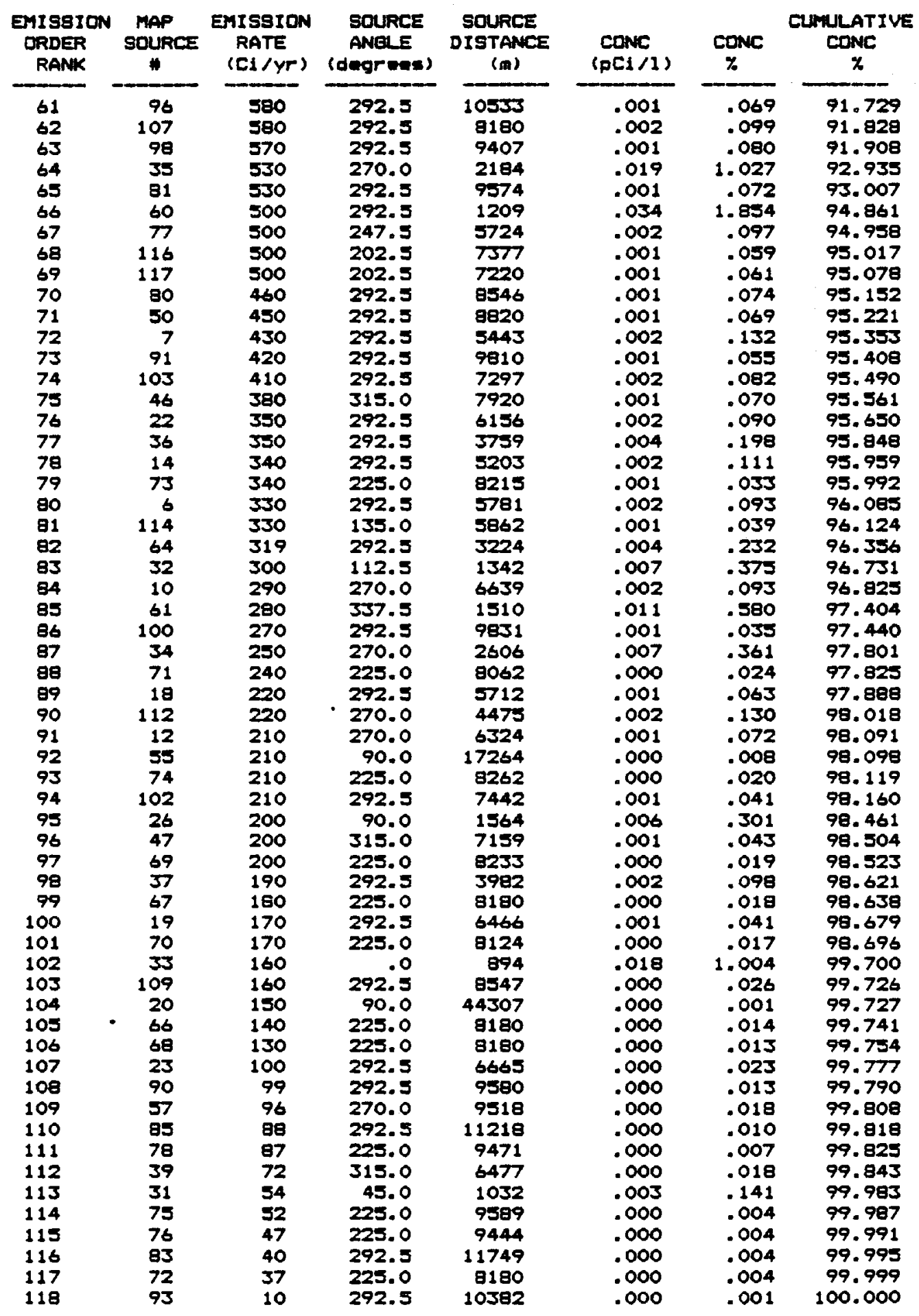


TABLE A.63. . Computed Radon Concentrations at Receptor 6.

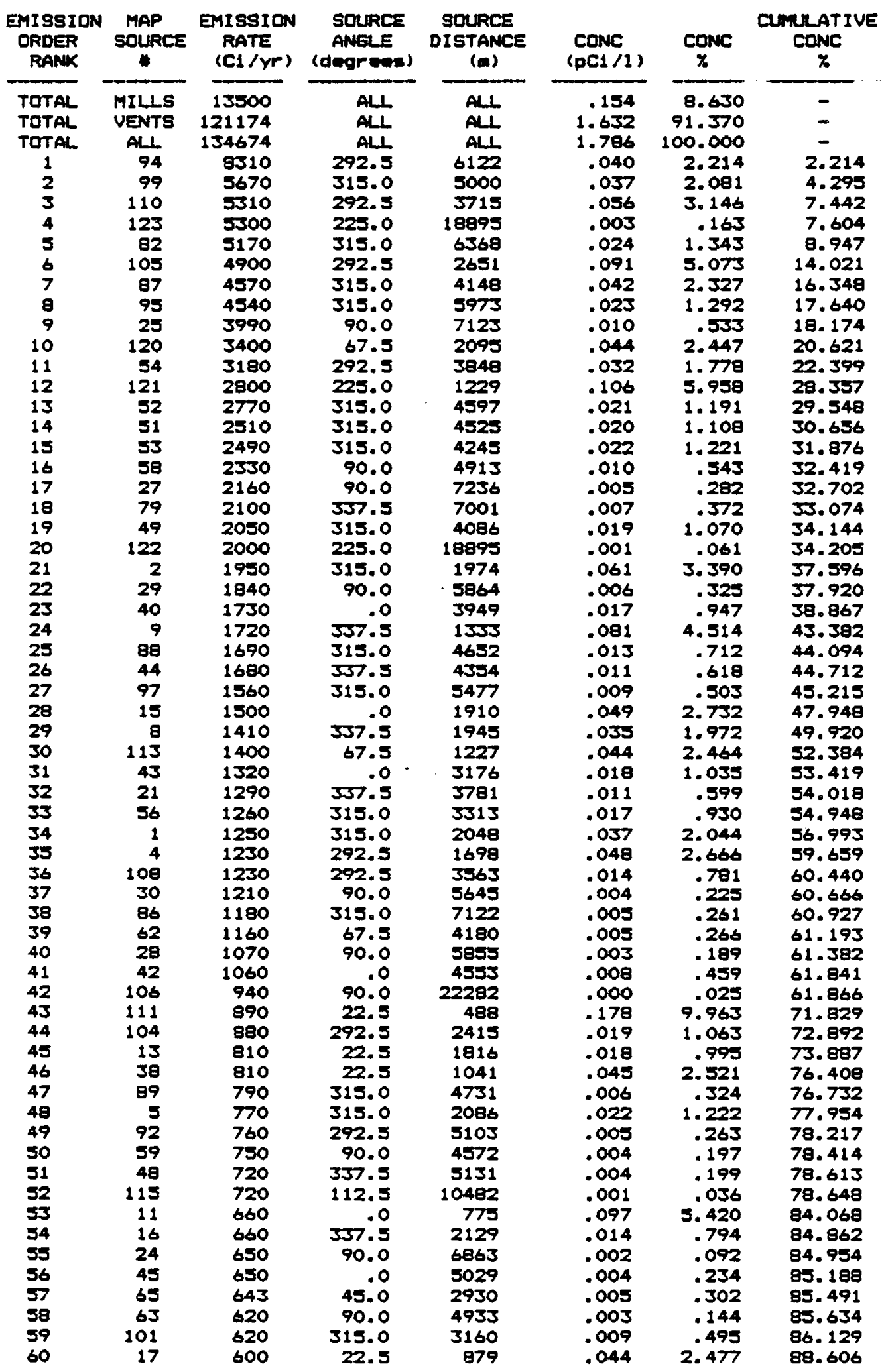


TABLE A.bb. Computed Radon Concentrations at Receptor 6.

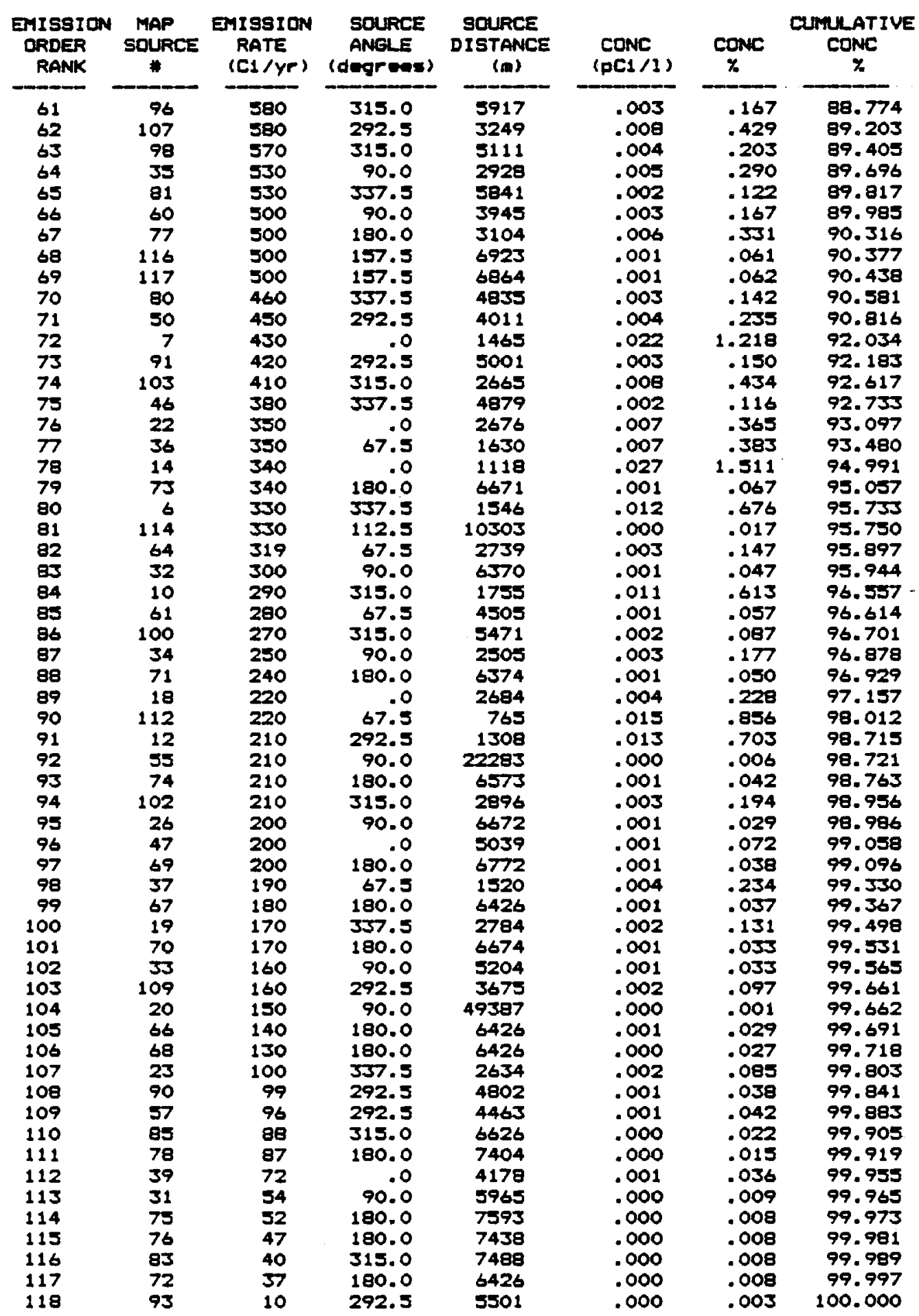


TABLE A.72. Computed Radon Concentrations at Racmptor 7.

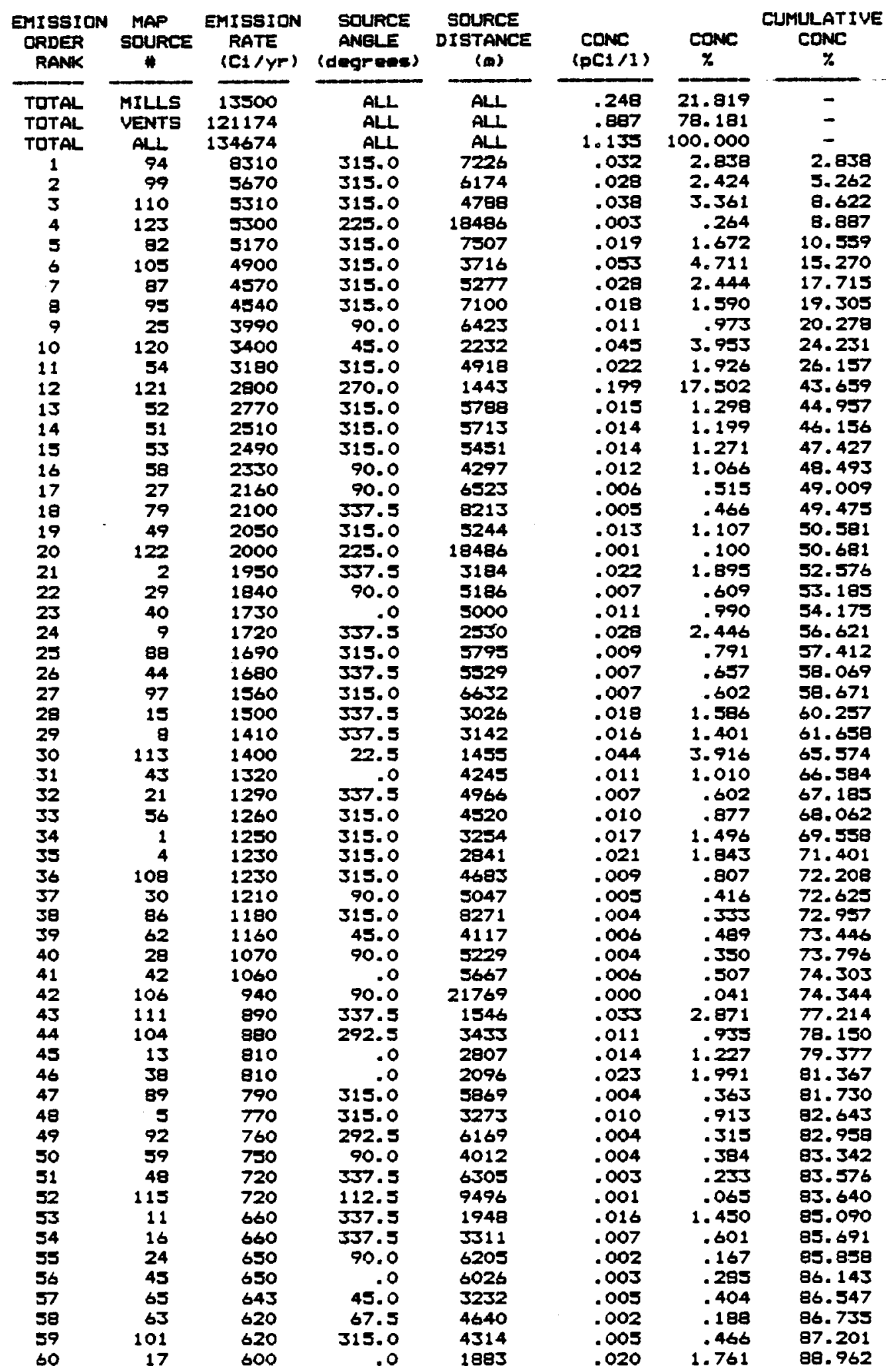


TABLE A.7b. Computed Radon Concmeratione at Receptor 7.

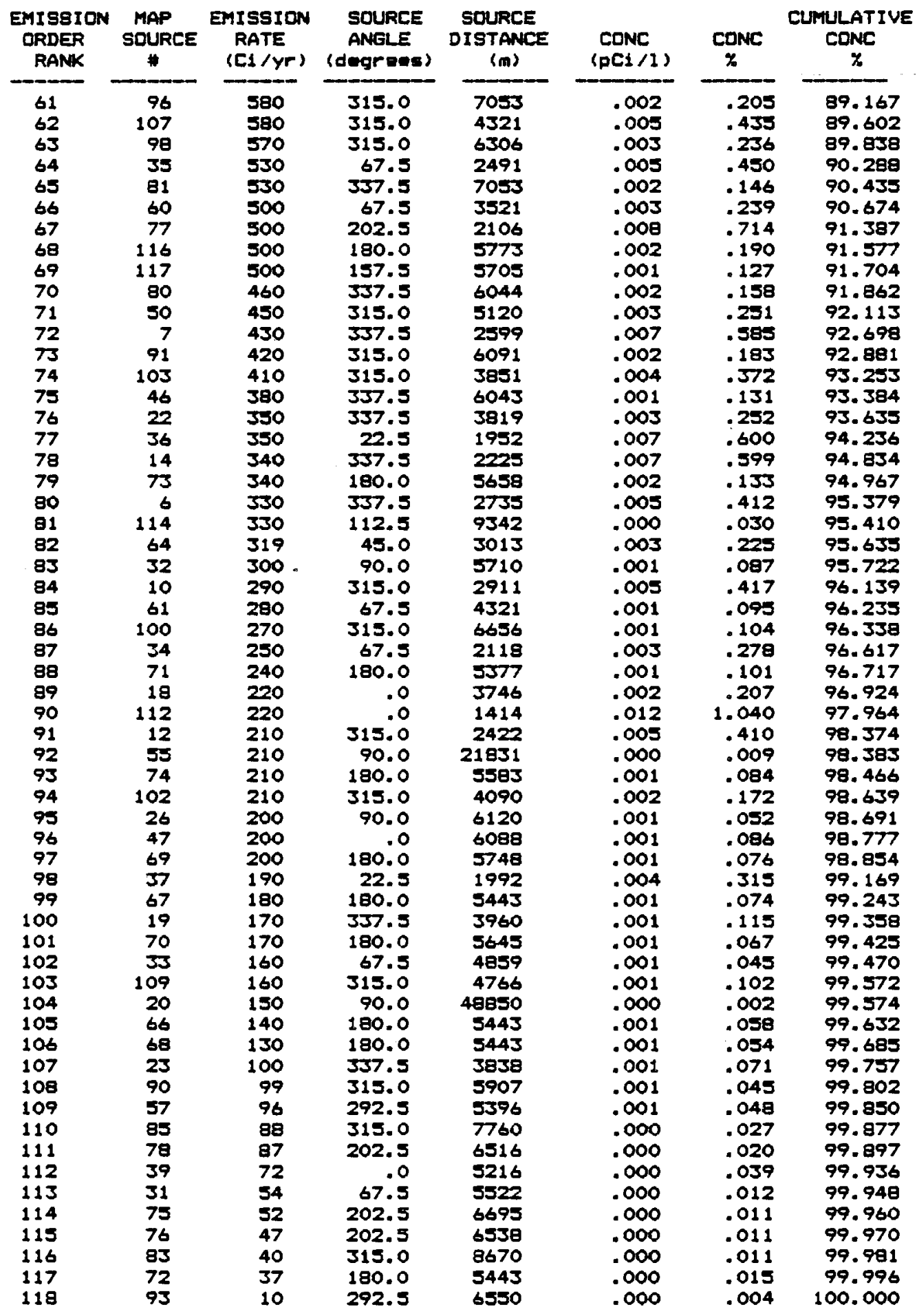


TABLE A.8a. Computed Radon Concontrations at Recaptor 8.

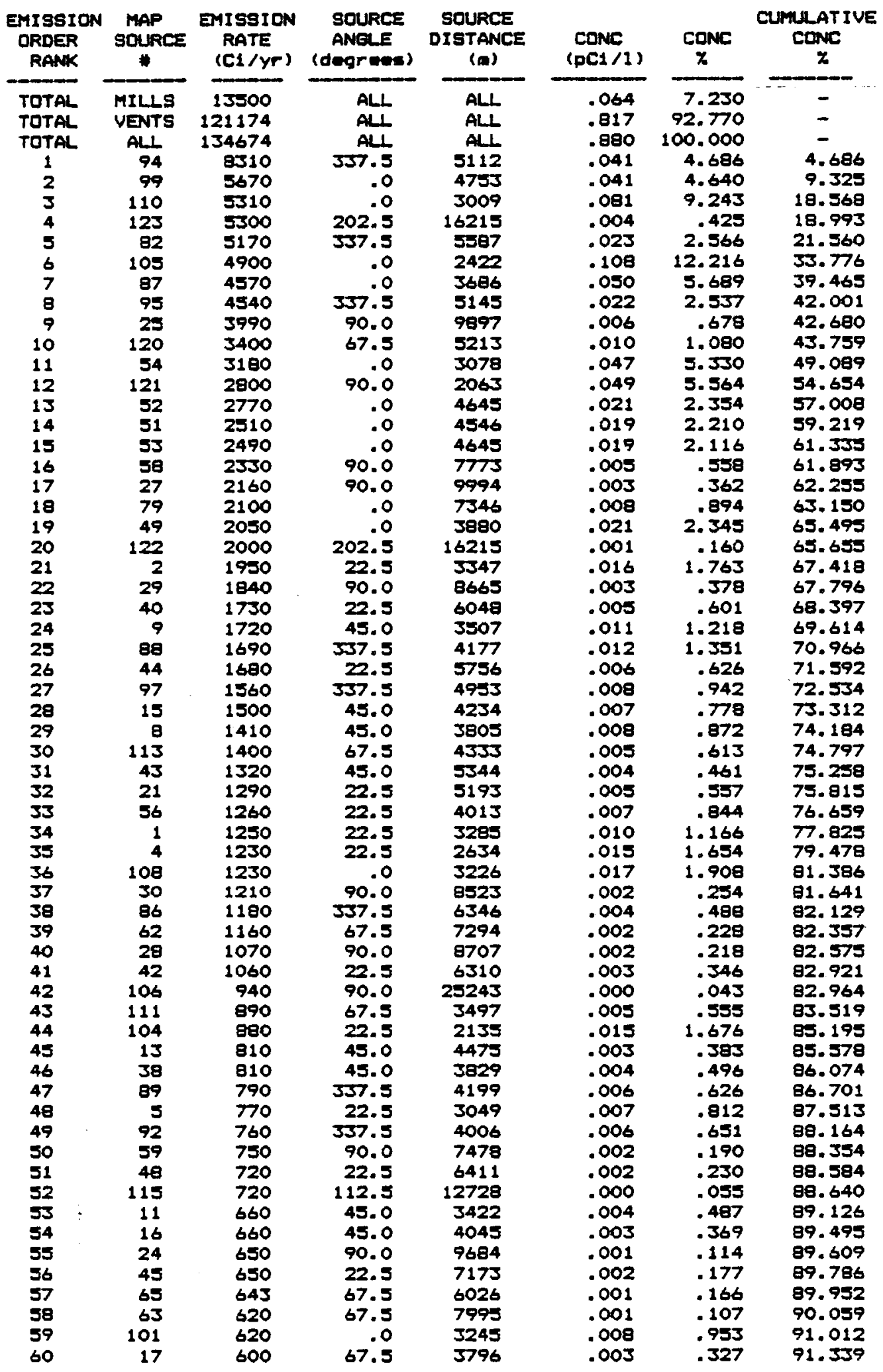


TABLE A.8b. Computad Radon Concontrations at Receptor 8.

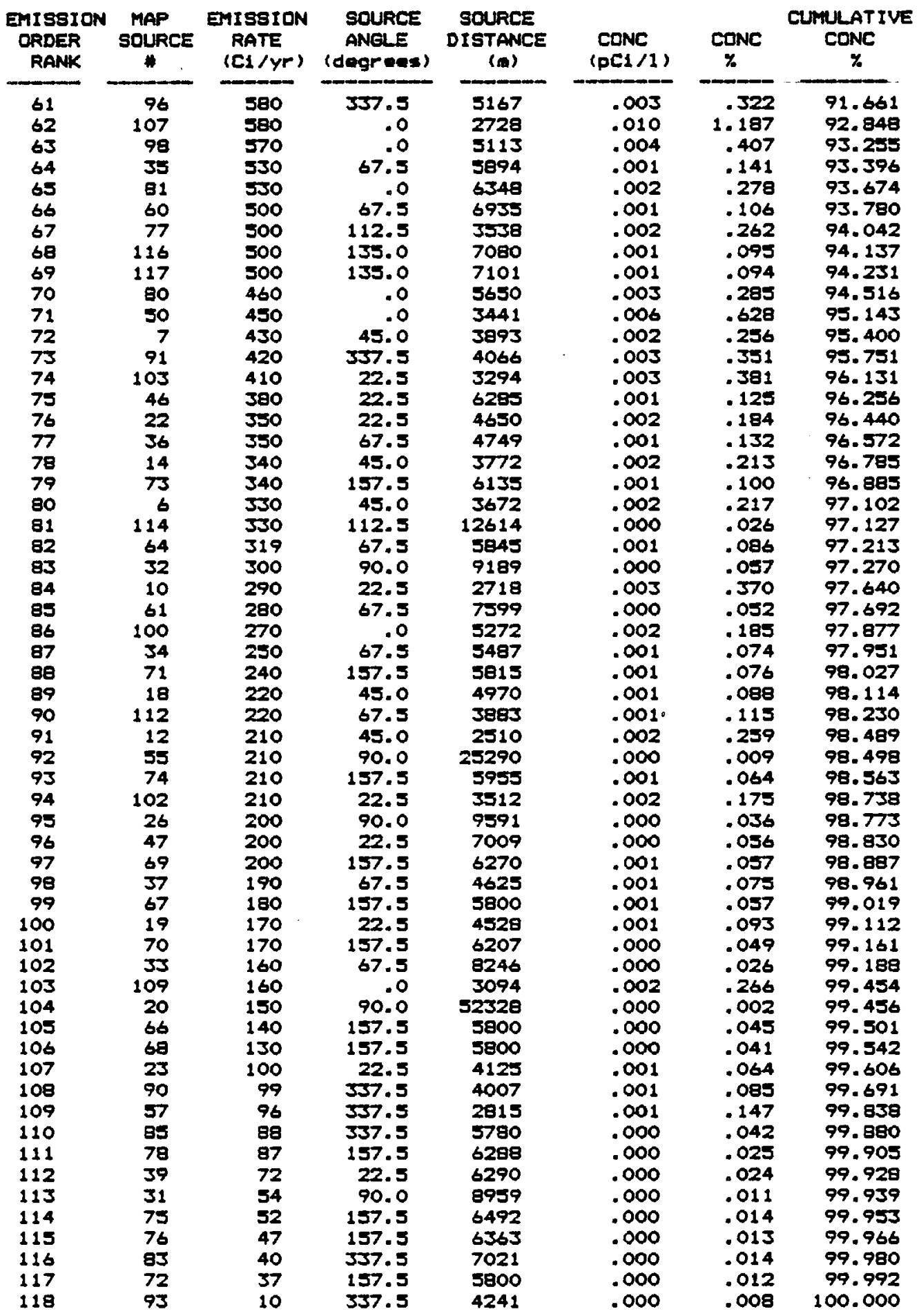


TABLE A.9a. Computod Radon Concontrations at Racoptor 9.

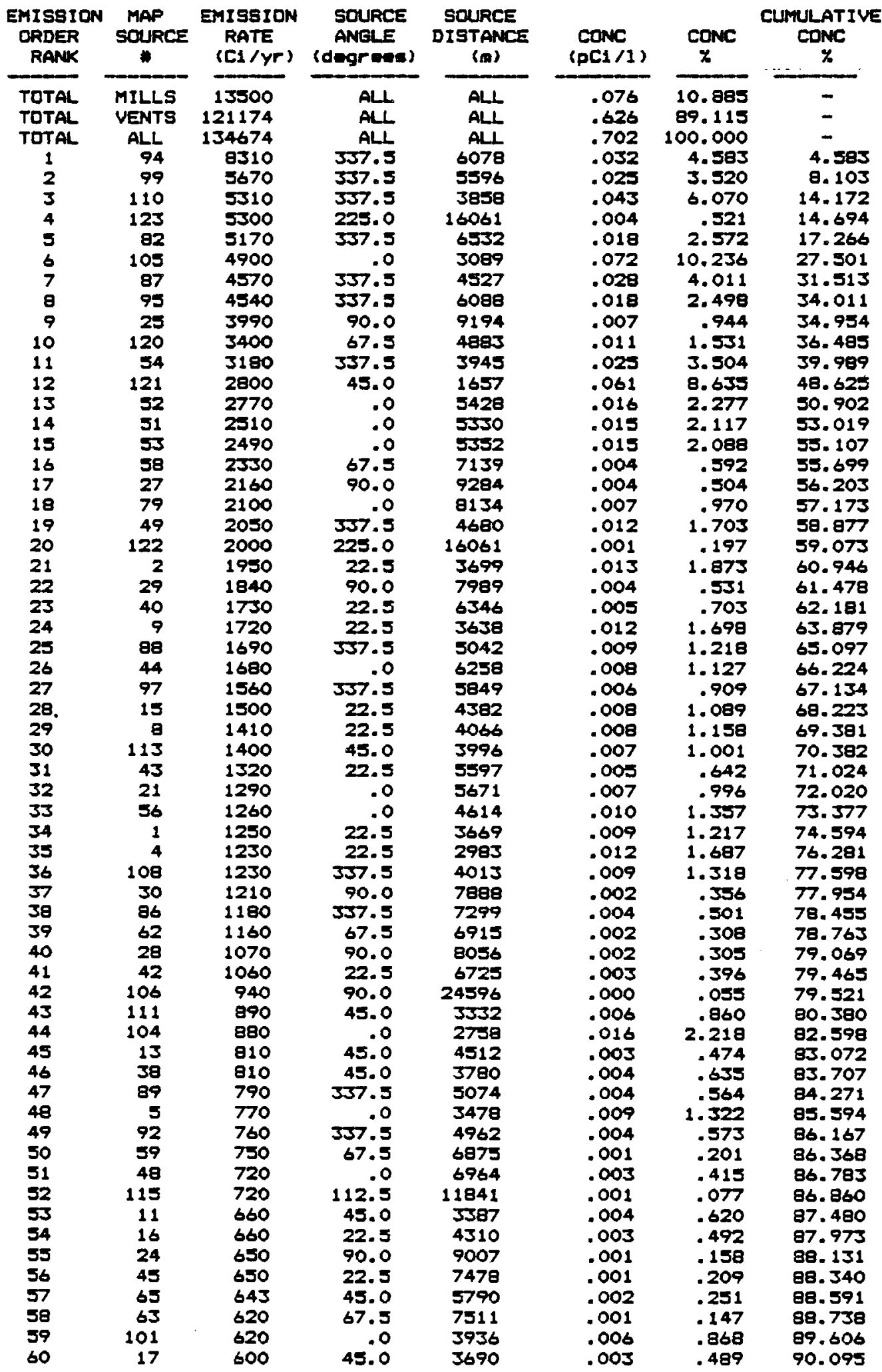


TABLE A. Ob. Computod Radon Concentrations at Recoptor 9.

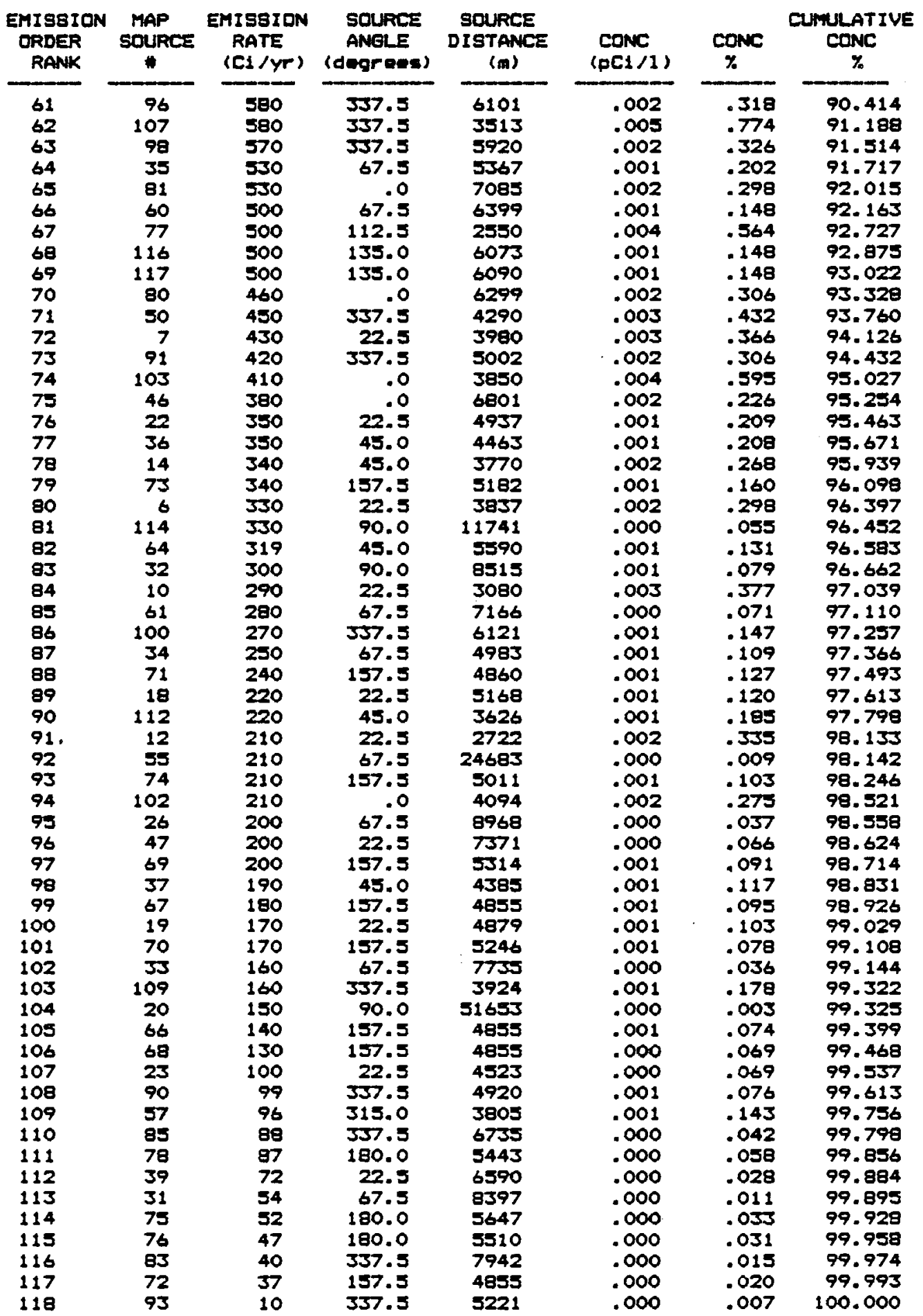


TABLE A.10a. Computed Radon Concantrations at Rocoptor 10.

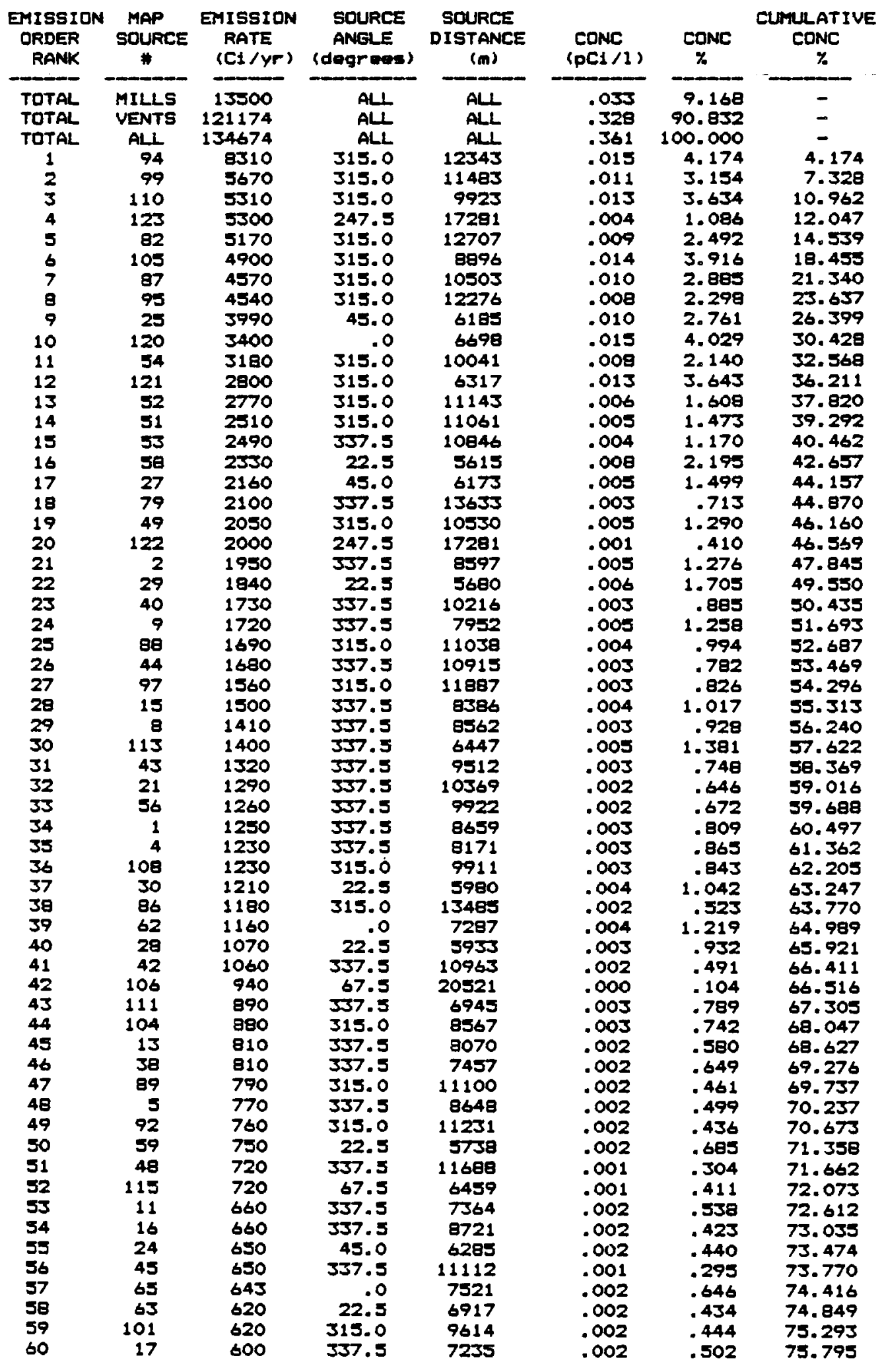


TABLE A.10b. Computed Radon Concentrations at Recnptor 10.

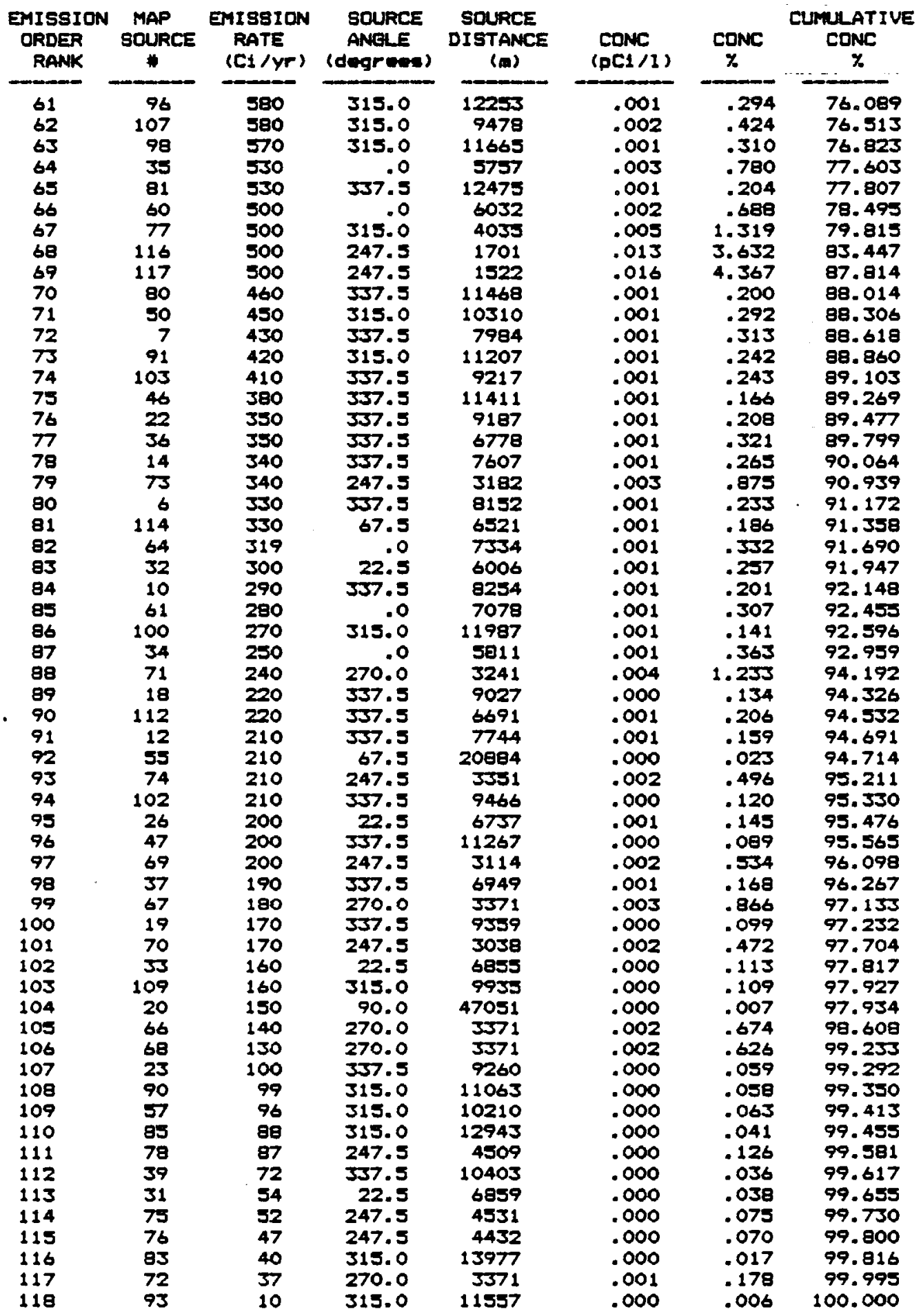


TABLE A.112. Computed Radon Concentrations at Rocoptor 11.

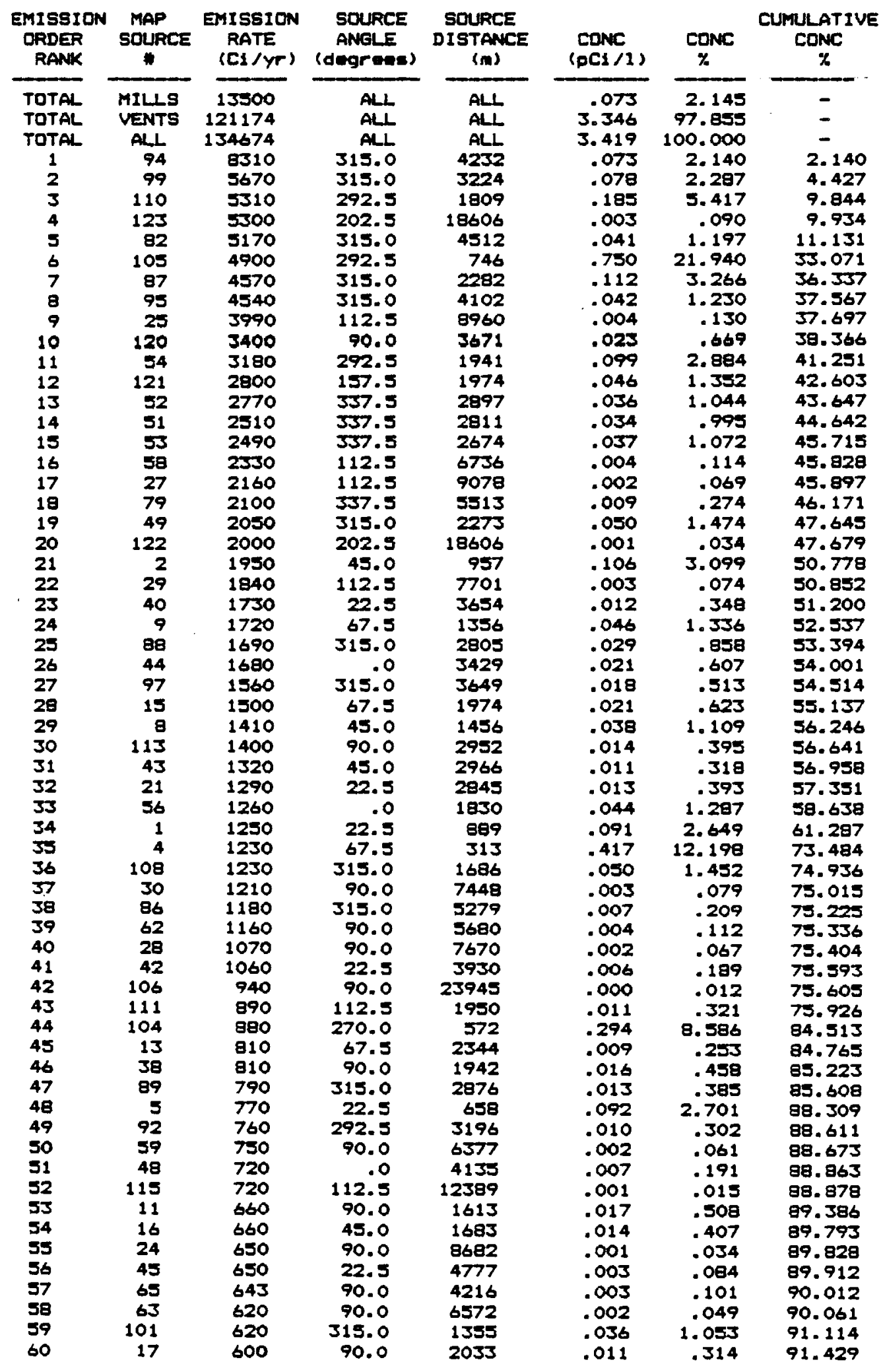


TABLE A.11b. Computed Radon Concentrations at Recoptor 11.

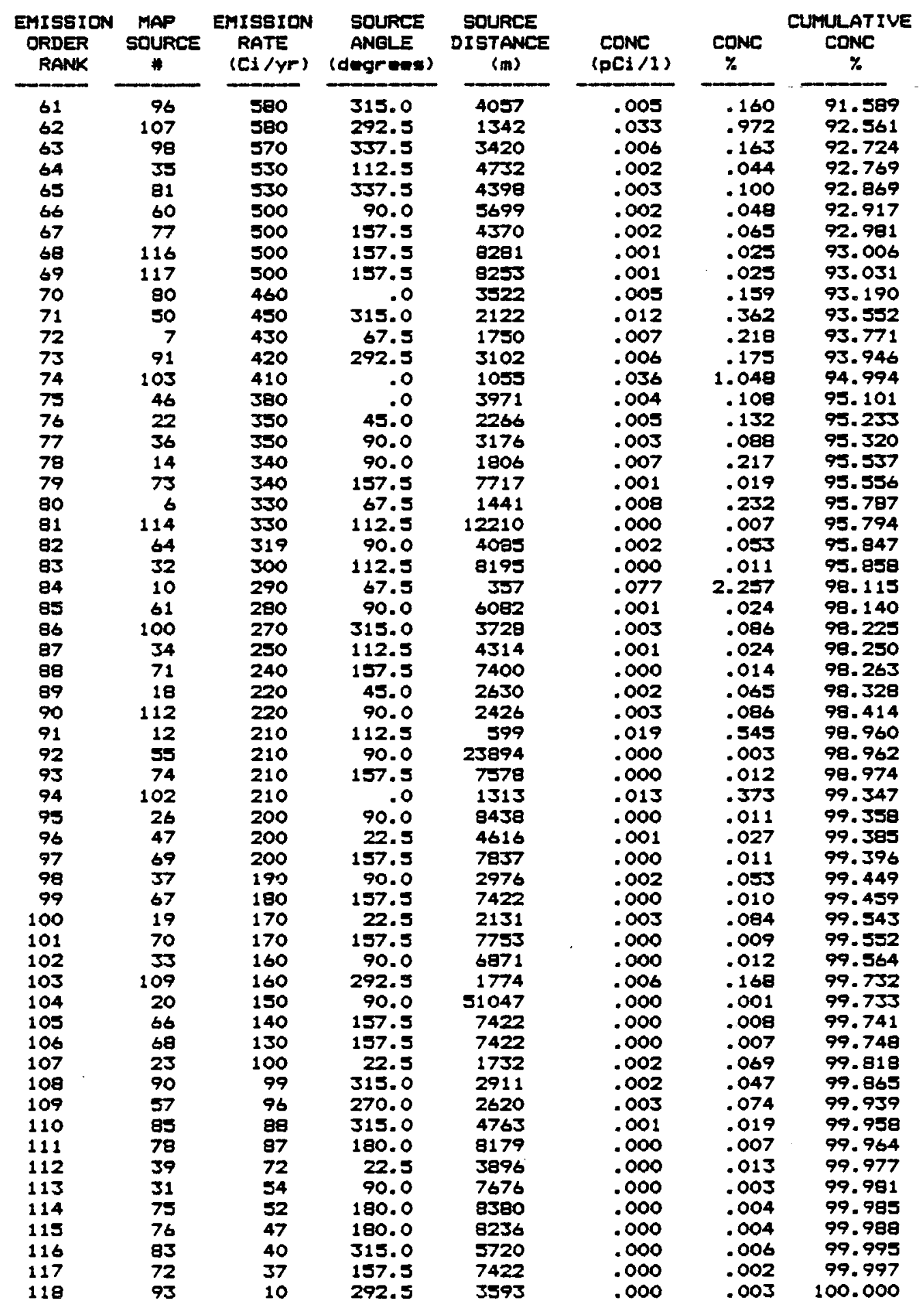


TABLE A.12a. Computad Radon Concentrations at Receptor 12.

\begin{tabular}{|c|c|c|c|c|c|c|c|}
\hline $\begin{array}{l}\text { EMISSION } \\
\text { ORDER } \\
\text { RAMK }\end{array}$ & $\begin{array}{l}\text { MAP } \\
\text { SOURCE } \\
*\end{array}$ & $\begin{array}{c}\text { EMISSION } \\
\text { RATE } \\
\text { (C1/Yr) }\end{array}$ & $\begin{array}{l}\text { SOURCE } \\
\text { ANGLE } \\
\text { (degraes) }\end{array}$ & $\begin{array}{c}\text { SOURCE } \\
\text { DISTANCE } \\
\text { (m) }\end{array}$ & $\begin{array}{c}\text { CONC } \\
(p C 1 / 1)\end{array}$ & $\frac{\text { CONC }}{x}$ & $\begin{array}{l}\text { CUMULATIVE } \\
\text { CONC } \\
x\end{array}$ \\
\hline $\begin{array}{c}\text { TOTAL } \\
\text { TOTAL } \\
\text { TOTAL } \\
1 \\
2 \\
3 \\
4 \\
5 \\
6 \\
7 \\
9 \\
9 \\
10\end{array}$ & $\begin{array}{c}\text { MILLS } \\
\text { VENTS } \\
\text { ALL } \\
94 \\
99 \\
110 \\
123 \\
82 \\
105 \\
87 \\
95 \\
25 \\
120\end{array}$ & $\begin{array}{r}13500 \\
121174 \\
134674 \\
8310 \\
5670 \\
5310 \\
5300 \\
5170 \\
4900 \\
4570 \\
4540 \\
3990 \\
3400\end{array}$ & $\begin{array}{r}A L L \\
\text { ALL } \\
\text { ALL } \\
292.5 \\
292.5 \\
270.0 \\
225.0 \\
292.5 \\
270.0 \\
292.5 \\
292.5 \\
112.5 \\
112.5\end{array}$ & $\begin{array}{r}A L L \\
A L L \\
A L L \\
5341 \\
4006 \\
3180 \\
20040 \\
5468 \\
2315 \\
3386 \\
5125 \\
7617 \\
2220\end{array}$ & $\begin{array}{r}.071 \\
5.146 \\
5.217 \\
.048 \\
.053 \\
.102 \\
.003 \\
.029 \\
.159 \\
.056 \\
.029 \\
.006 \\
.034\end{array}$ & $\begin{array}{r}1.362 \\
98.638 \\
100.000 \\
.922 \\
1.016 \\
1.947 \\
.051 \\
.555 \\
3.039 \\
1.081 \\
.535 \\
.107 \\
.649\end{array}$ & $\begin{array}{c}- \\
- \\
- \\
.922 \\
1.938 \\
3.985 \\
3.937 \\
4.491 \\
7.530 \\
9.611 \\
9.145 \\
9.253 \\
9.902\end{array}$ \\
\hline 11 & 54 & 3180 & 270.0 & 3307 & .057 & 1.093 & 10.995 \\
\hline 12 & 121 & 2800 & 202.5 & 2527 & .034 & .642 & 11.637 \\
\hline 13 & 52 & 2770 & 292.5 & 3530 & .032 & .612 & 12.248 \\
\hline 14 & 51 & 2510 & 292.5 & 3479 & .030 & .568 & 12.816 \\
\hline $\begin{array}{l}15 \\
16\end{array}$ & $\begin{array}{l}53 \\
58\end{array}$ & $\begin{array}{l}2490 \\
2330\end{array}$ & $\begin{array}{l}315.0 \\
112.5\end{array}$ & $\begin{array}{l}3080 \\
5406\end{array}$ & $\begin{array}{l}.037 \\
.005\end{array}$ & $\begin{array}{l}.710 \\
.102\end{array}$ & $\begin{array}{l}13.526 \\
13.628\end{array}$ \\
\hline 17 & 27 & 2160 & 112.5 & 7744 & .003 & .057 & 13.685 \\
\hline 18 & 79 & 2100 & 315.0 & 5669 & .012 & .221 & 13.905 \\
\hline 19 & 49 & 2050 & 292.5 & 3216 & .028 & .528 & 14.434 \\
\hline 20 & 122 & 2000 & 225.0 & 20040 & .001 & .019 & 14.453 \\
\hline 21 & 2 & 1950 & 270.0 & 1021 & .246 & 4.721 & 19.174 \\
\hline 22 & 29 & 1840 & 112.5 & 6378 & .003 & .064 & 19.237 \\
\hline $\begin{array}{l}23 \\
24\end{array}$ & $\begin{array}{r}40 \\
9\end{array}$ & $\begin{array}{l}1730 \\
1720\end{array}$ & $\begin{array}{r}.0 \\
225.0\end{array}$ & $\begin{array}{r}2455 \\
387\end{array}$ & $\begin{array}{l}.037 \\
.474\end{array}$ & $\begin{array}{r}.712 \\
9.089\end{array}$ & $\begin{array}{l}19.949 \\
29.038\end{array}$ \\
\hline $\begin{array}{l}25 \\
26\end{array}$ & $\begin{array}{l}88 \\
44\end{array}$ & $\begin{array}{l}1690 \\
1680\end{array}$ & $\begin{array}{l}292.5 \\
357.5\end{array}$ & $\begin{array}{l}3805 \\
2871\end{array}$ & $\begin{array}{l}.017 \\
.022\end{array}$ & $\begin{array}{r}.330 \\
.422\end{array}$ & $\begin{array}{l}29.368 \\
29.790\end{array}$ \\
\hline 27 & 97 & 1560 & 292.5 & 4547 & .012 & .227 & 30.017 \\
\hline 28 & 15 & 1500 & .0 & 403 & .684 & 13.115 & 43.132 \\
\hline 29 & 日 & 1410 & 292.5 & 612 & .301 & 5.766 & 48.898 \\
\hline 30 & 113 & 1400 & 135.0 & 1790 & .022 & .415 & 49.313 \\
\hline 31 & 43 & 1320 & .0 & 1680 & .053 & 1.019 & 50.332 \\
\hline 32 & 21 & 1290 & 337.5 & 2319 & .024 & .461 & 50.794 \\
\hline 33 & 56 & 1260 & 292.5 & 2181 & .032 & .617 & 51.411 \\
\hline 34 & 1 & 1250 & 270.0 & 1145 & .130 & 2.501 & 53.912 \\
\hline 35 & 4 & 1230 & 247.5 & 1410 & .044 & .844 & 54.756 \\
\hline 36 & 108 & 1230 & 270.0 & 2886 & .028 & .530 & 55.286 \\
\hline 37 & 30 & 1210 & 112.5 & 6070 & .002 & .045 & 55.331 \\
\hline $\begin{array}{l}38 \\
39\end{array}$ & $\begin{array}{l}86 \\
62\end{array}$ & $\begin{array}{l}1180 \\
1160\end{array}$ & $\begin{array}{r}292.5 \\
90.0\end{array}$ & $\begin{array}{l}6171 \\
4069\end{array}$ & .006 & $\begin{array}{l}.106 \\
.126\end{array}$ & $\begin{array}{l}55.437 \\
55.563\end{array}$ \\
\hline 40 & 28 & 1070 & 112.5 & 6306 & .002 & .038 & 55.601 \\
\hline 41 & 42 & 1060 & .0 & 3035 & .016 & .307 & 55.900 \\
\hline 42 & 106 & 940 & 90.0 & 22345 & .000 & .009 & 55.916 \\
\hline 43 & 111 & 890 & 157.5 & 1114 & .038 & .732 & 56.648 \\
\hline 44 & 104 & 880 & 247.5 & 2274 & .014 & .273 & 56.921 \\
\hline 45 & 13 & 810 & 67.5 & 621 & .080 & 1.535 & 58.456 \\
\hline 46 & 38 & 810 & 135.0 & 605 & .077 & 1.480 & 59.936 \\
\hline 47 & 89 & 790 & 292.5 & 3898 & .008 & .148 & 60.084 \\
\hline 48 & 5 & 770 & 270.0 & 1364 & .060 & 1.150 & 61.234 \\
\hline 49 & 92 & 760 & 270.0 & 4474 & .008 & .159 & 61.392 \\
\hline 50 & 59 & 750 & 112.5 & 5024 & .002 & .036 & 61.429 \\
\hline 51 & 48 & 720 & 337.5 & 3646 & .006 & .122 & 61.550 \\
\hline 32 & 115 & 720 & 112.5 & 11324 & .001 & .011 & 61.561 \\
\hline 53 & 11 & 660 & 180.0 & 744 & .084 & 1.608 & 63.170 \\
\hline 54 & 16 & 660 & 315.0 & 689 & .119 & 2.276 & 65.446 \\
\hline 55 & 24 & 650 & 112.5 & 7309 & .001 & .019 & 65.465 \\
\hline 36 & 45 & 650 & 22.5 & 3561 & .005 & .090 & 65.554 \\
\hline 57 & 65 & 643 & 90.0 & 2557 & .008 & .151 & 65.705 \\
\hline 58 & 63 & 620 & 90.0 & 5029 & .002 & .047 & 65.752 \\
\hline 59 & 101 & 620 & 270.0 & 2397 & .019 & .363 & 66.115 \\
\hline 60 & 17 & 600 & 157.5 & 825 & .043 & .815 & 66.930 \\
\hline
\end{tabular}


TABLE A.12b. Computed Radon Concentrations at Recoptor 12.

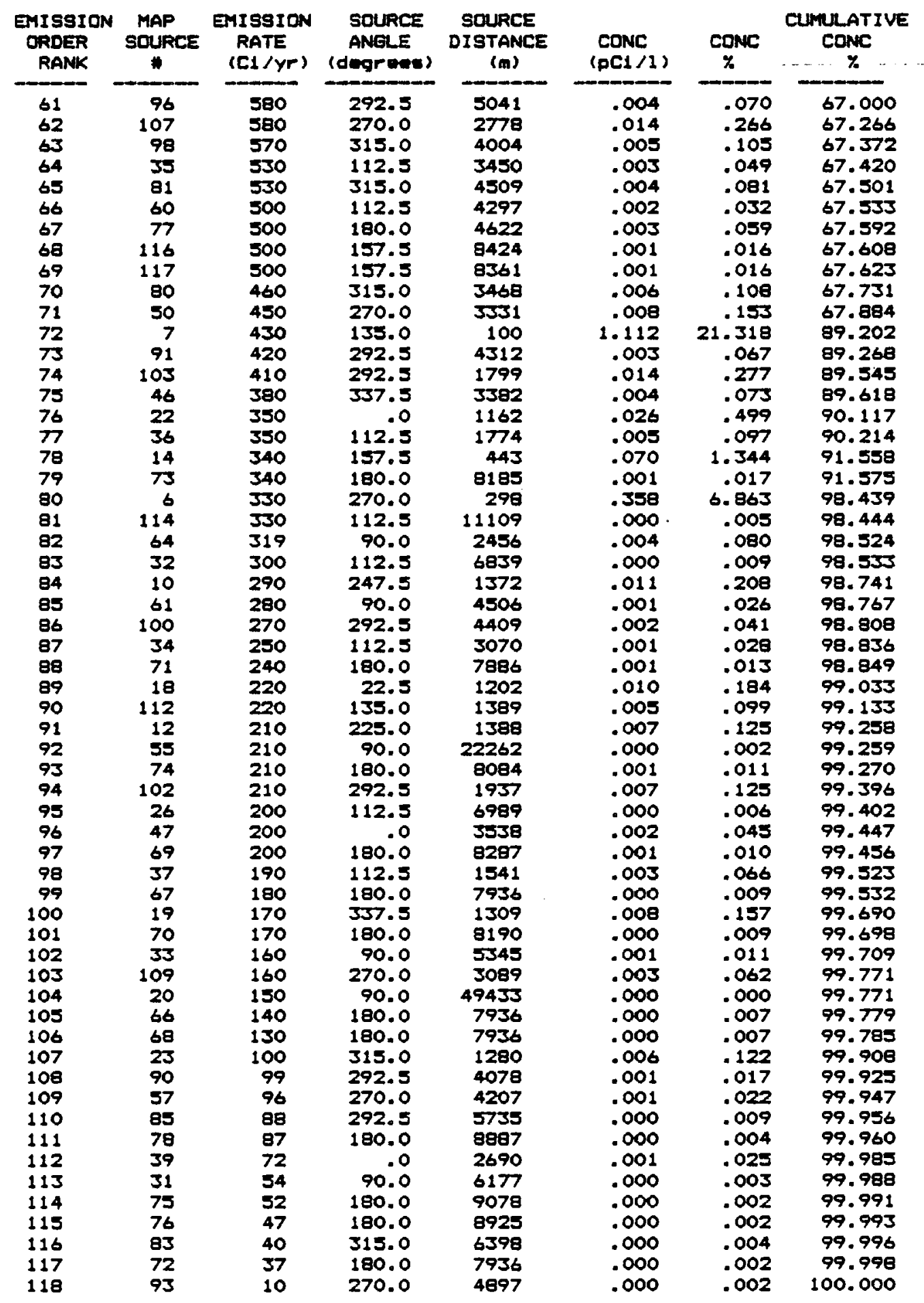


TABLE A.13. Largest Computed Concmerations at Receptor 1.

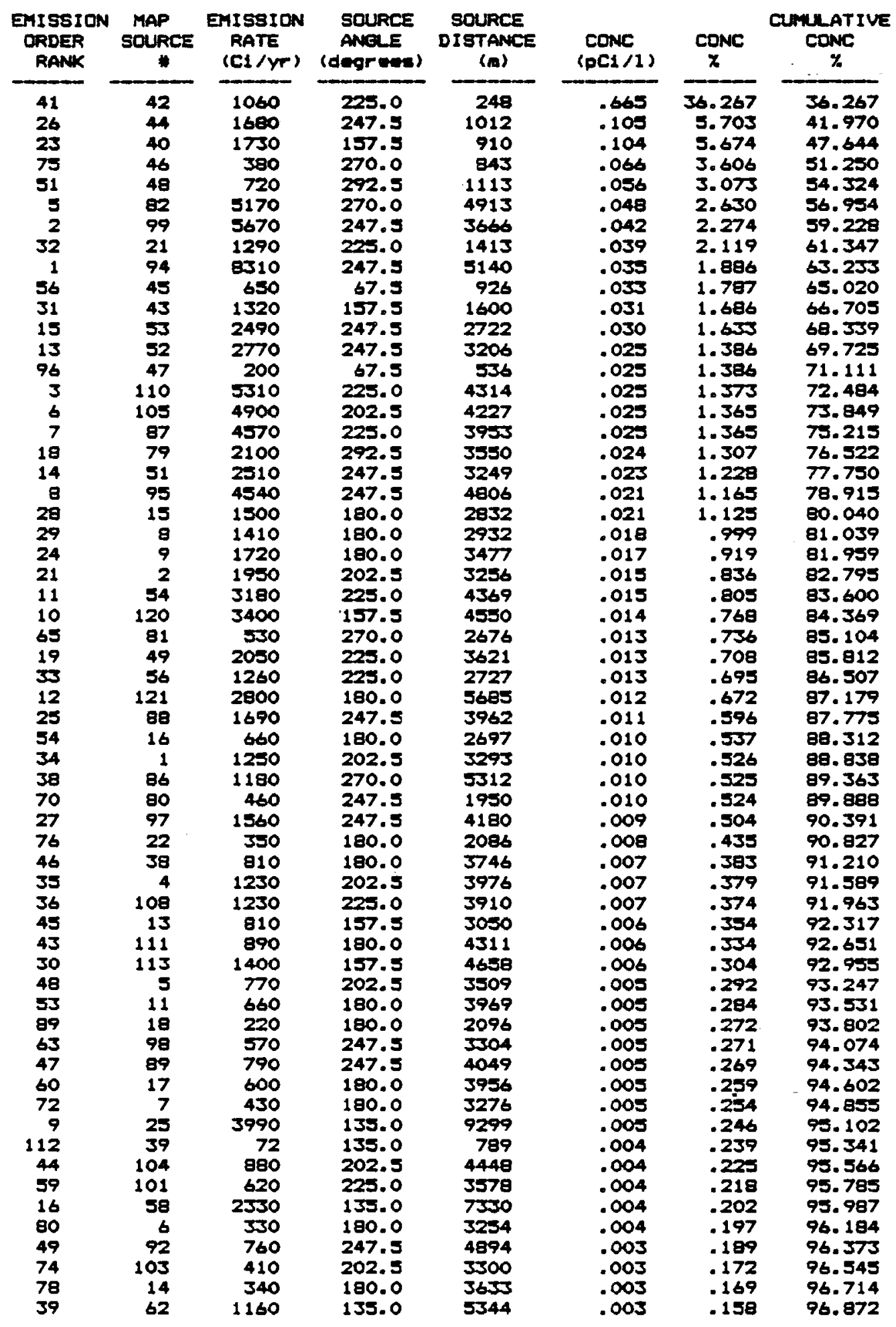


TABLE A.14. Largent Computed Concmerationi at Recoptor 2.

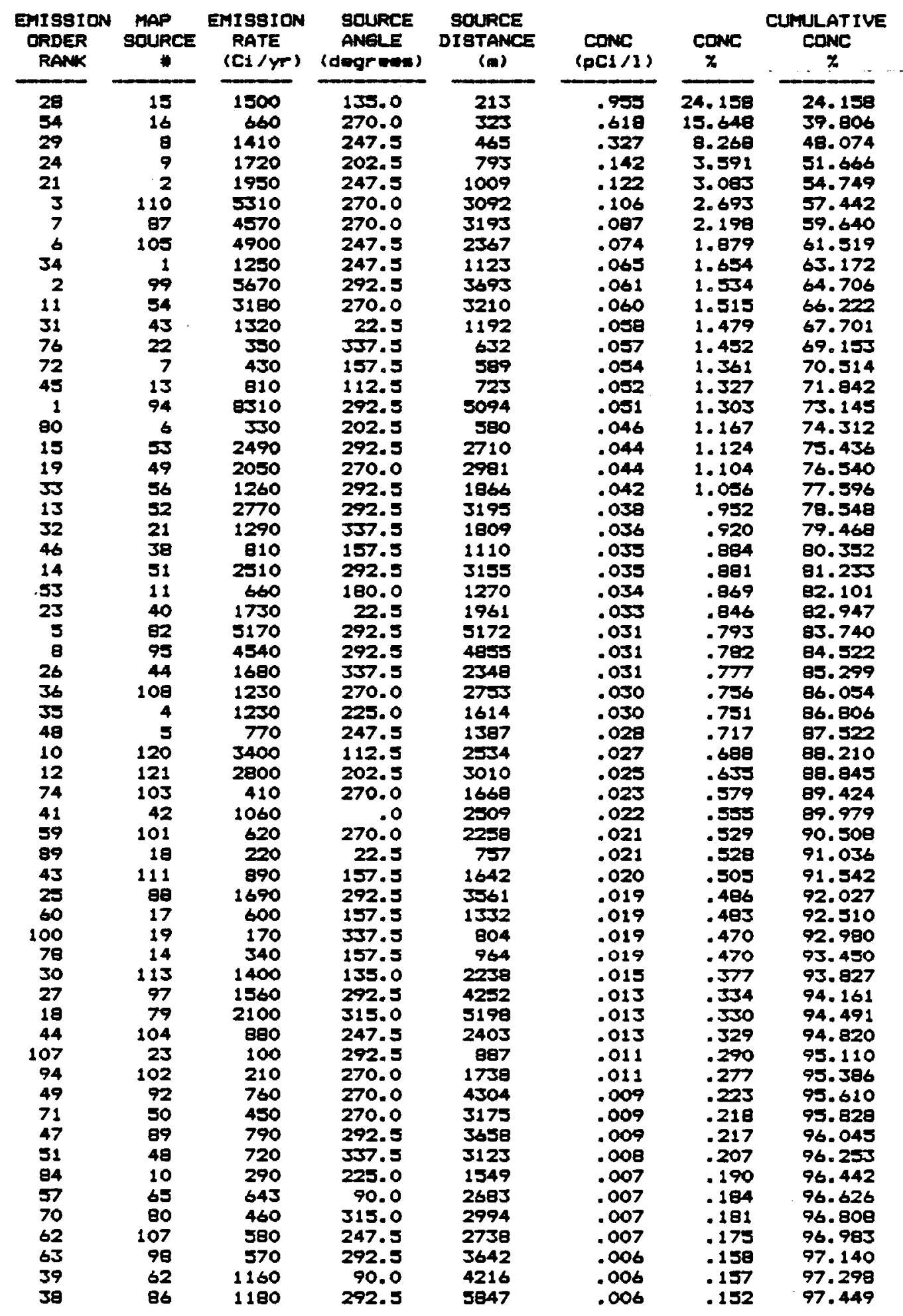


TABLE A.15. Largost Computed Concentrations at Recoptor 3.

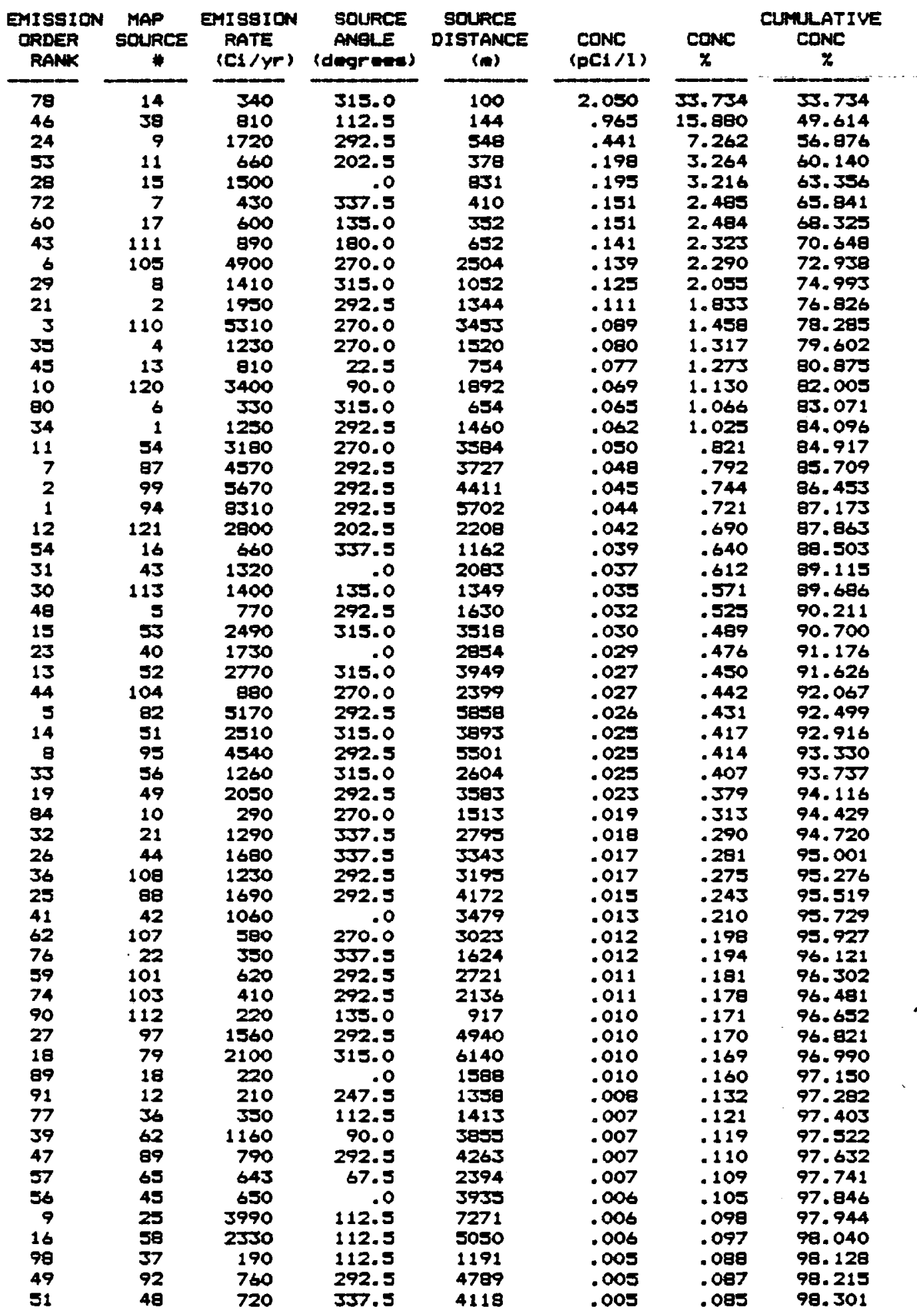


TAELE A.16. Largert Computed Conentratione at Receptor 4.

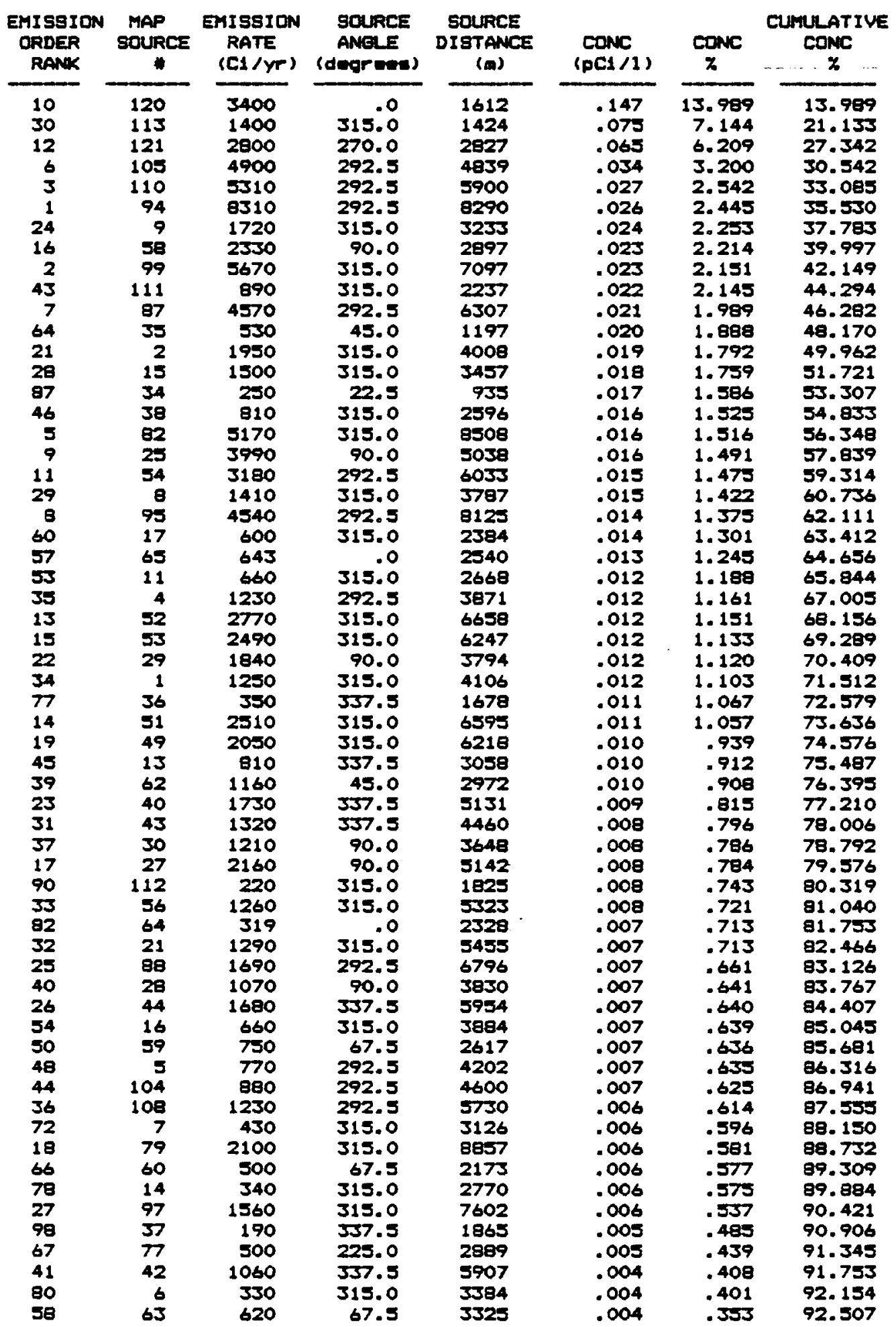


TABLE A.17. Largest Computed Concantrations at Recaptor 5.

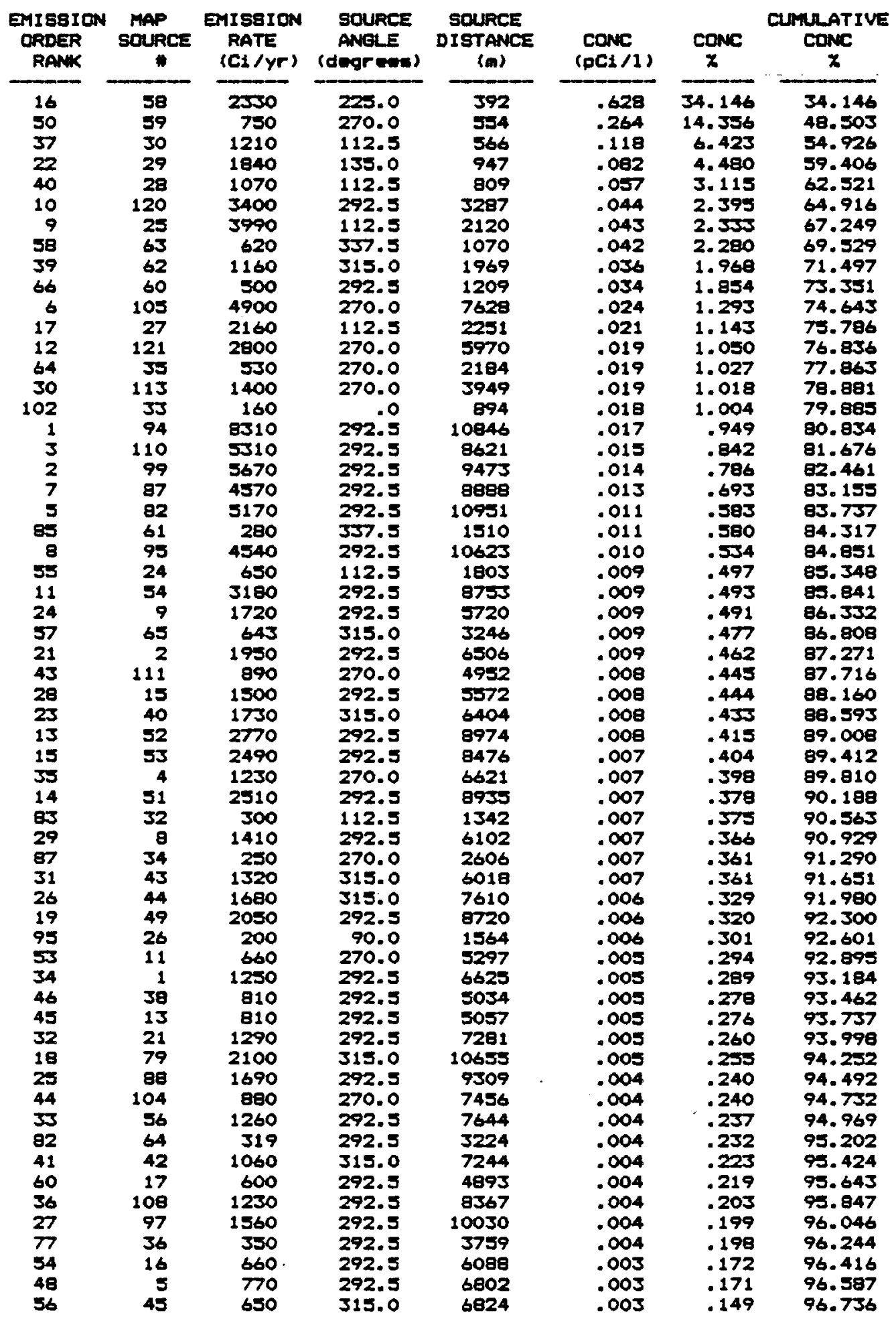


TABLE A.1日. Largest Computed Concentratione at Rueaptor 6.

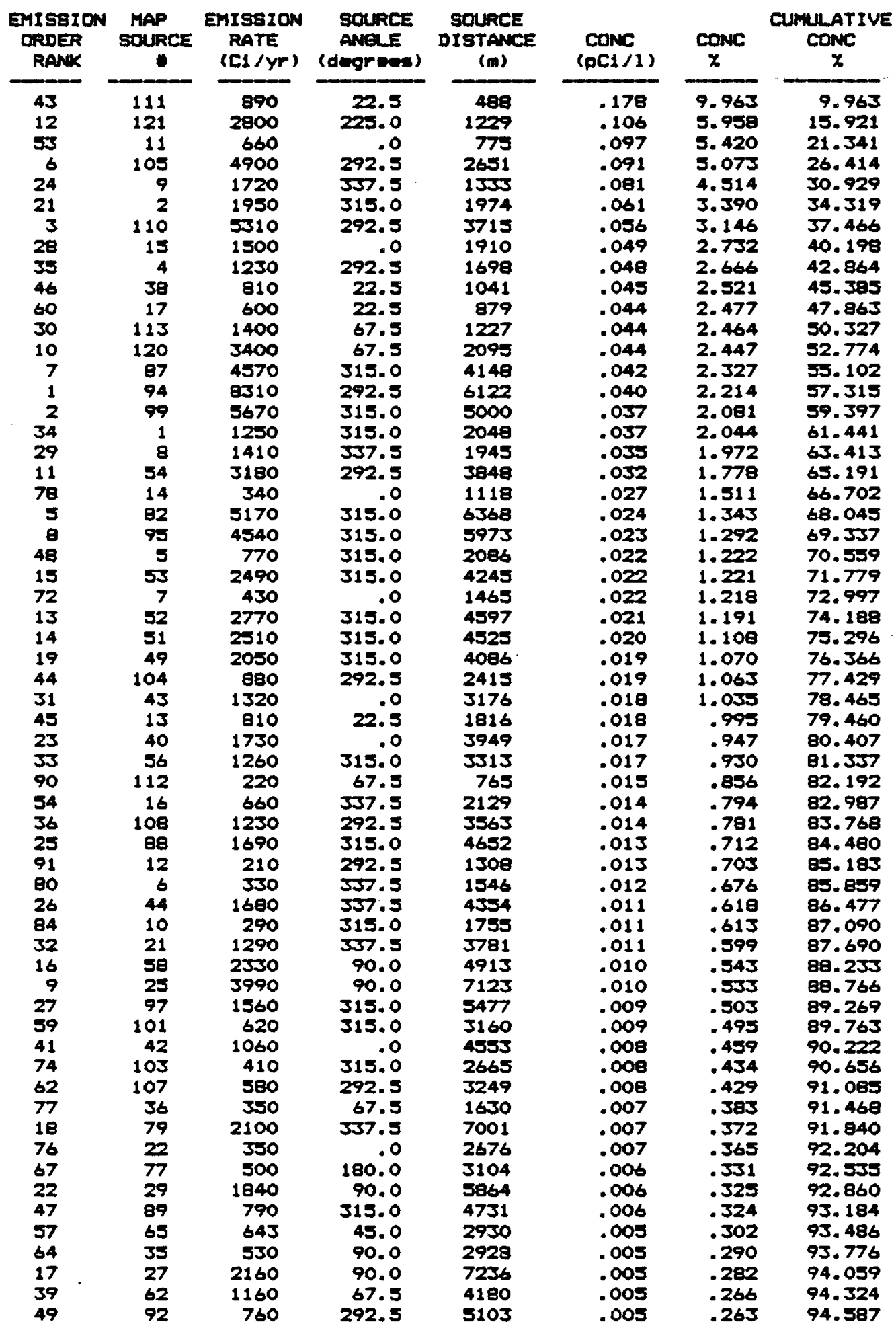


TABLE A.19. Largent Computed Concmirations at Recmptor 7.

\begin{tabular}{|c|c|c|c|c|c|c|c|}
\hline $\begin{array}{l}\text { DMISEION } \\
\text { ORDER } \\
\text { RANK }\end{array}$ & $\begin{array}{c}\text { MAP } \\
\text { SOURCE }\end{array}$ & $\begin{array}{l}\text { EMISBION } \\
\text { RATE } \\
\text { (CI/YF) }\end{array}$ & $\begin{array}{l}\text { SOURCE } \\
\text { ANGLE } \\
\text { (degrems) }\end{array}$ & $\begin{array}{l}\text { SOURCE } \\
\text { DISTANCE } \\
\text { (an) }\end{array}$ & $\begin{array}{l}\text { CONC } \\
\left(p C_{1 / 1}\right)\end{array}$ & $\underset{x}{\text { conc }}$ & $\begin{array}{c}\text { CLMLATIVE } \\
\text { CONC } \\
\%\end{array}$ \\
\hline 12 & 121 & 2800 & 270.0 & 1443 & .199 & 17.502 & 17.502 \\
\hline 6 & 105 & 4900 & 315.0 & 3716 & .053 & 4.711 & 22.213 \\
\hline 10 & 120 & 3400 & 45.0 & 2232 & .045 & 3.953 & 26.166 \\
\hline 30 & 113 & 1400 & 22.5 & 1455 & .044 & 3.916 & 30.062 \\
\hline 3 & 110 & 5310 & 315.0 & 4788 & .038 & 3.361 & 33.443 \\
\hline 43 & 111 & 990 & 337.5 & 1546 & .035 & 2.871 & 36.313 \\
\hline 1 & 94 & 8310 & 315.0 & 7226 & .032 & 2.838 & 39.152 \\
\hline 24 & 9 & 1720 & 337.5 & 2530 & .028 & 2.446 & 41.598 \\
\hline 7 & 87 & 4570 & 315.0 & 3277 & .028 & 2.444 & 44.042 \\
\hline 2 & 99 & 5670 & 315.0 & 6174 & .028 & 2.424 & 46.466 \\
\hline 46 & 38 & 810 & .0 & 2096 & .023 & 1.991 & 48.457 \\
\hline 11 & 54 & 3180 & 315.0 & 4918 & .022 & 1.926 & 50.382 \\
\hline 21 & 2 & 1950 & 337.5 & 3184 & .022 & 1.895 & 52.277 \\
\hline 35 & 4 & 1230 & 315.0 & 2841 & .021 & 1.843 & 54.120 \\
\hline 60 & 17 & 600 & .0 & 1893 & .020 & 1.761 & 58.891 \\
\hline 5 & 82 & 5170 & 315.0 & 7507 & .019 & 1.672 & 57.554 \\
\hline 8 & 95 & 4540 & 315.0 & 7100 & .018 & 1.590 & 59.144 \\
\hline 28 & 15 & 1500 & 337.5 & 3026 & .018 & 1.586 & 60.730 \\
\hline 34 & 1 & 1250 & 315.0 & 3254 & .017 & 1.496 & 62.226 \\
\hline 53 & 12 & 660 & 337.5 & 1948 & $.016^{\circ}$ & 1.450 & 63.675 \\
\hline 29 & 8 & 1410 & 337.5 & 3142 & .016 & 1.401 & 65.076 \\
\hline 13 & 52 & 2770 & 315.0 & 5788 & .015 & $1.29 \theta$ & 66.374 \\
\hline 15 & 53 & 2490 & 315.0 & 5451 & .014 & 1.271 & 67.646 \\
\hline 45 & 13 & 810 & .0 & 2807 & .014 & 1.227 & 68.872 \\
\hline 14 & 51 & 2510 & 315.0 & 5713 & .014 & 1.199 & 70.071 \\
\hline 19 & 49 & 2050 & 315.0 & 5244 & .013 & 1.107 & 71.178 \\
\hline 16 & 58 & 2330 & 90.0 & 4297 & .012 & 1.066 & 72.244 \\
\hline 90 & 112 & 220 & .0 & 1414 & .012 & 1.040 & 73.284 \\
\hline 31 & 43 & 1320 & .0 & 4245 & .011 & 1.010 & 74.293 \\
\hline 23 & 40 & 1730 & .0 & 5000 & .011 & .990 & 75.283 \\
\hline 9 & 25 & 3990 & 90.0 & 6423 & .011 & .973 & 76.256 \\
\hline 44 & 104 & 880 & 292.5 & 3433 & .011 & .935 & 77.192 \\
\hline 48 & $\mathbf{s}$ & 770 & 315.0 & 3273 & .010 & .913 & 78.104 \\
\hline 33 & 56 & 1260 & 315.0 & 4520 & .010 & .877 & 78.981 \\
\hline 36 & 108 & 1230 & 315.0 & 4683 & .009 & .807 & 79.789 \\
\hline 25 & 88 & 1690 & 315.0 & 5795 & .009 & .791 & 80.580 \\
\hline 67 & $\pi$ & 500 & 202.5 & 2106 & .008 & .714 & 81.293 \\
\hline 26 & 44 & 1680 & 337.5 & 5529 & .007 & .657 & 81.950 \\
\hline 22 & 29 & 1840 & 90.0 & 5186 & .007 & .609 & 82.559 \\
\hline$\overline{27}$ & 97 & 1560 & 315.0 & 6632 & .007 & .602 & 83.161 \\
\hline 32 & 21 & 1290 & 337.5 & 4966 & .007 & .602 & 83.763 \\
\hline 54 & 16 & 660 & 337.5 & 3311 & .007 & .601 & 84.364 \\
\hline 77 & 36 & 350 & 22.5 & 1952 & .007 & .600 & 84.964 \\
\hline 78 & 14 & 340 & 337.5 & 2223 & .007 & .599 & 85.563 \\
\hline 72 & 7 & 430 & 337.5 & 2599 & .007 & .585 & 86.148 \\
\hline 17 & 27 & 2160 & 90.0 & 6523 & .006 & .515 & 86.663 \\
\hline 41 & 42 & 1060 & .0 & 5667 & .006 & .507 & 87.170 \\
\hline 39 & 62 & 1160 & 45.0 & 4117 & .006 & .489 & 87.659 \\
\hline 18 & 79 & 2100 & 337.5 & 8213 & .005 & .466 & 88.125 \\
\hline 59 & 101 & 620 & 315.0 & 4314 & .005 & .466 & 88.591 \\
\hline 64 & 35 & 530 & 67.5 & 2491 & .005 & .450 & 89.041 \\
\hline 62 & 107 & 580 & 315.0 & 4321 & .005 & .435 & 89.476 \\
\hline 84 & 10 & 290 & 315.0 & 2911 & .005 & .417 & 89.893 \\
\hline 37 & 30 & 1210 & 90.0 & 5047 & .005 & .416 & 90.310 \\
\hline 80 & 6 & 330 & 337.5 & 2735 & .005 & .412 & 90.722 \\
\hline 91 & 12 & 210 & 315.0 & 2422 & .005 & .410 & 91.132 \\
\hline 57 & 65 & 643 & 45.0 & 3232 & .005 & .404 & 91.536 \\
\hline so & 59 & 750 & 90.0 & 4012 & .004 & .384 & 91.921 \\
\hline 74 & 103 & 410 & 315.0 & 3851 & .004 & .372 & 92.292 \\
\hline 47 & 89 & 790 & 315.0 & 5869 & .004 & .363 & 92.655 \\
\hline
\end{tabular}


TABLE A.20. Largout Computad Concentrations at Receptor 8.

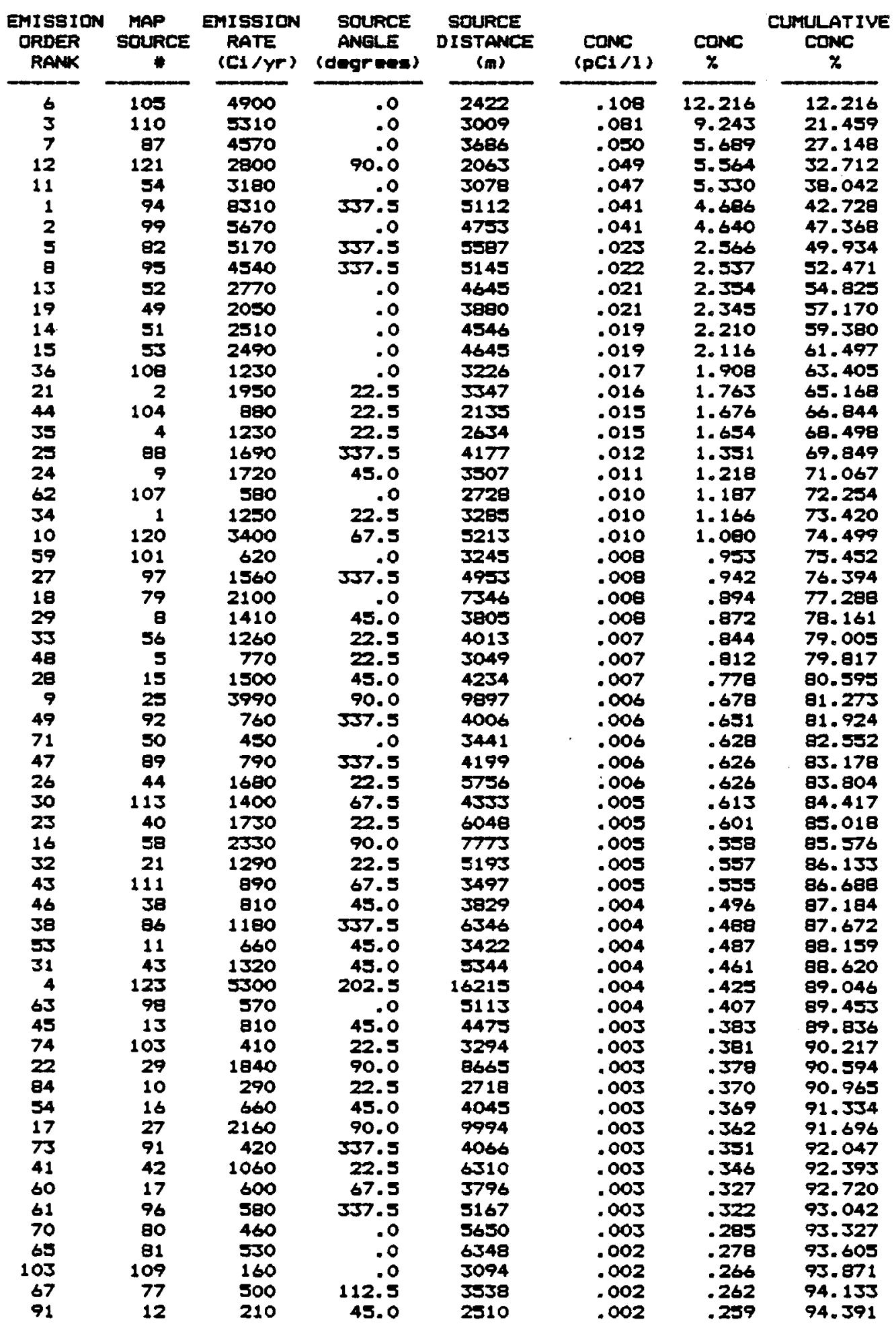


TABLE A.21. Largest Computed Concantrations at Rnceptor 9.

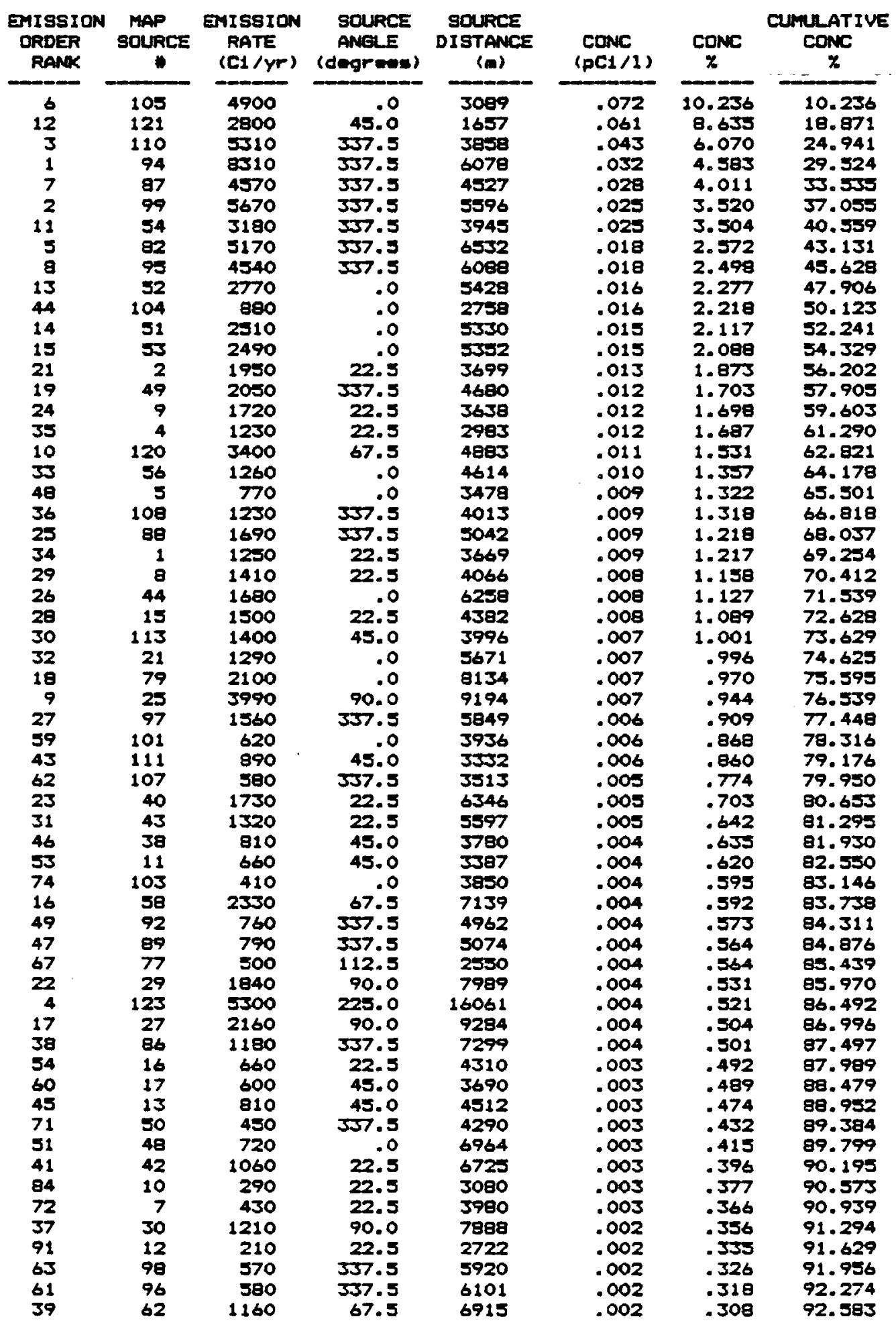


TABLE A.22. Largost Computed Concmerations at Receptor 10.

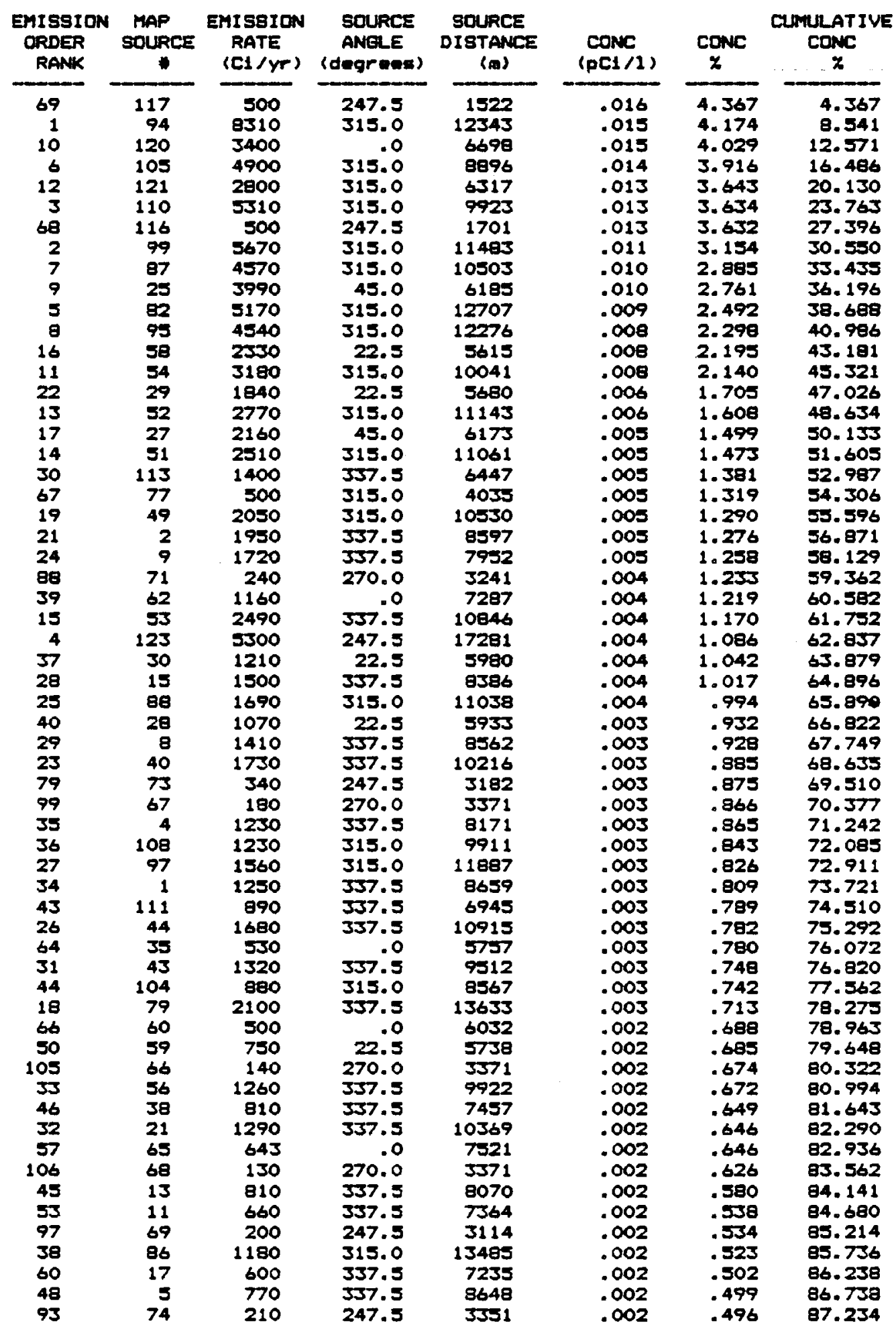


TABLE A.23. Largost Computed Concentrations at Roceptor 11.

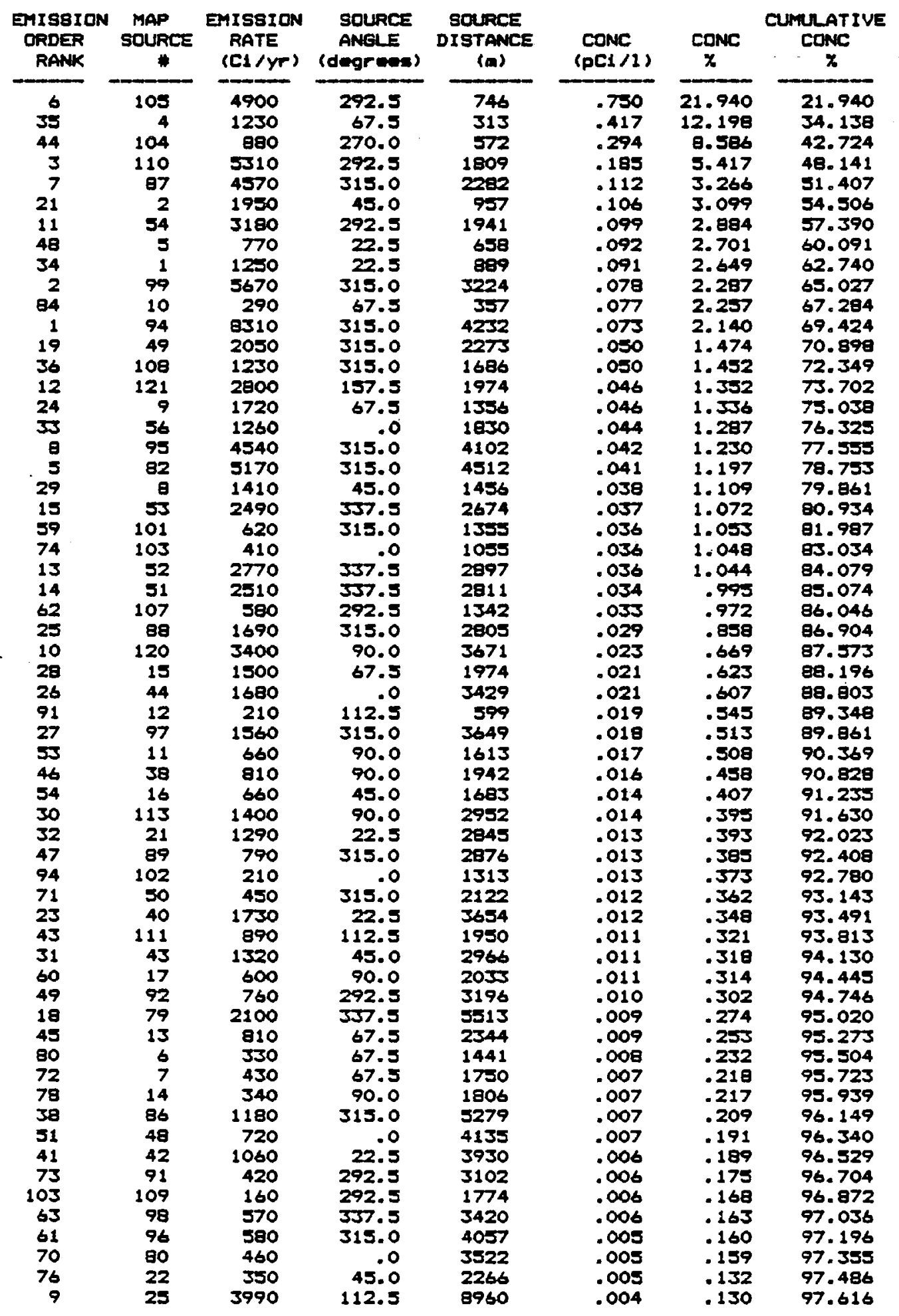


TABLE A.24. Largent Computed Concentratione at Receptor 12.

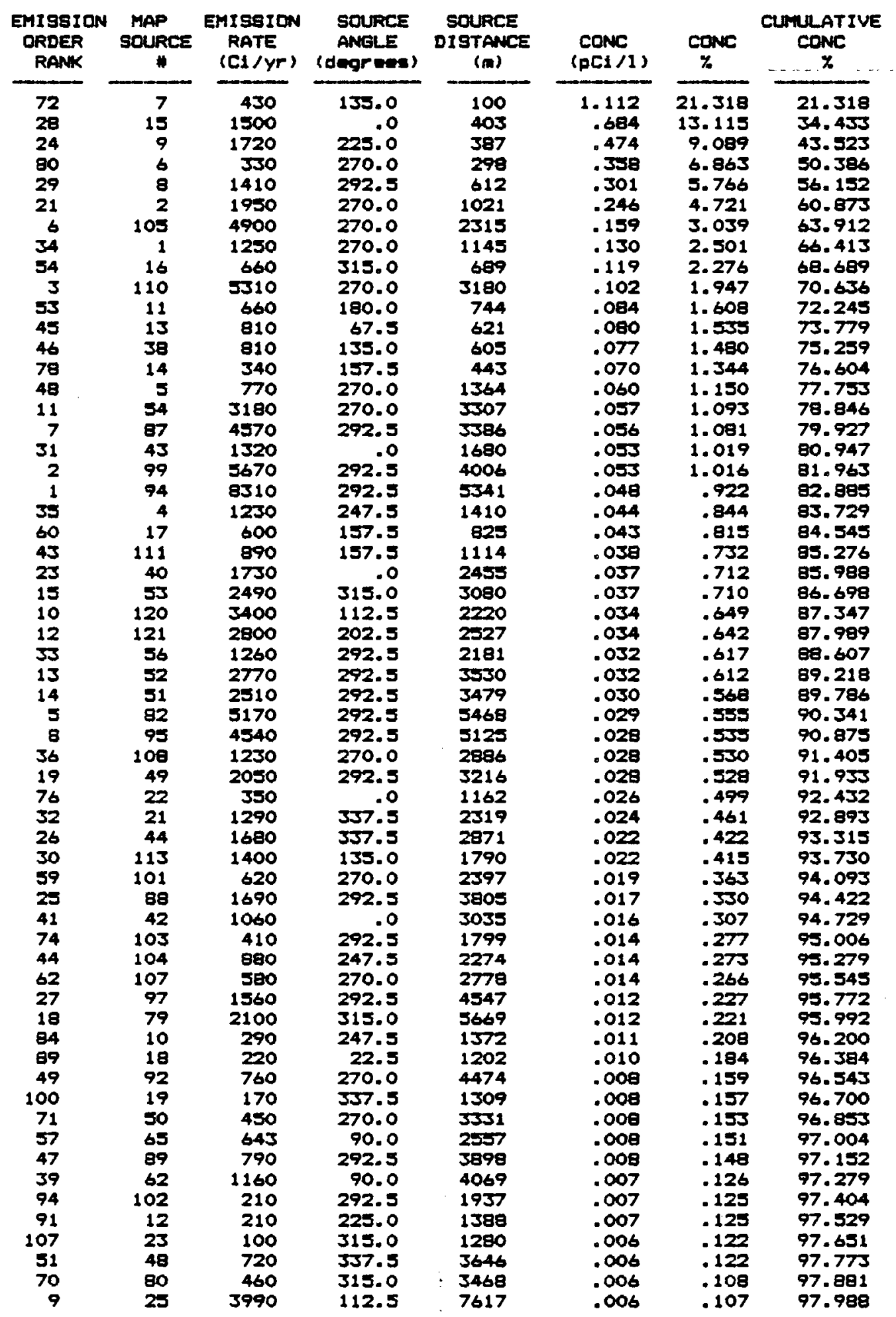

